\title{
Model Tingkat Perkembangan Pelorongan Akuifer Karst Untuk Identifikasi Kapasitas Penyerapan Karbon Sebagai Antisipasi Bencana Pemanasan Iklim Global
}

By:

Tjahyo Nugroho Adji dan Eko Haryono 


\section{PREPRINTS VERSION}

2018 


\section{LAPORAN AKHIR \\ PENELITIAN TIM PASCASARJANA}

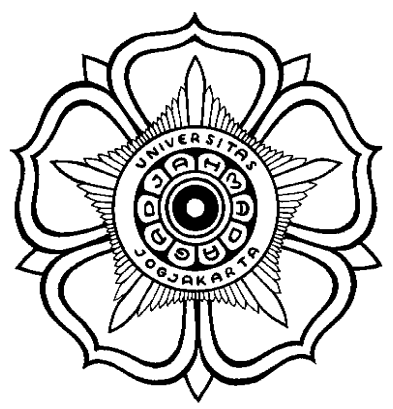

MODEL TINGKAT PERKEMBANGAN PELORONGAN AKUIFER KARST UNTUK IDENTIFIKASI KAPASITAS PENYERAPAN KARBON SEBAGAI ANTISIPASI BENCANA PEMANASAN IKLIM GLOBAL

Tahun ke-1 (satu) dari rencana 3 (tiga) tahun

Dr. Tjahyo Nugroho Adji, M.Sc.Tech. (0028017202)

(Jurusan Geografi Lingkungan)

Dr. Eko Haryono, MSi. (0024026601)

(Jurusan Geografi Lingkungan)

DIBIAYAI OLEH:

DIREKTORAT RISET DAN PENGABDIAN MASYARAKAT

DIREKTORAT JENDERAL PENGUATAN RISET DAN PENGEMBANGAN

KEMENTERIAN RISET, TEKNOLOGI, DAN PENDIDIKAN TINGGI

SESUAI DENGAN KONTRAK PENELITIAN TAHUN ANGGARAN 2017

UNIVERSITAS GADJAH MADA

November 2017 


\section{RINGKASAN}

Penelitian ini dilakukan pada dua mataair yang terletak pada dua akuifer karst, yatu Mataair Kakap yang terletak di kawasan karst Gunungsewu dan Mataair Sumbersemen yang terletak di kawasan karst Rembang. Penelitian tahun ke-1 ini mempunyai tujuan untuk (1) mendefinisikan sifat akuifer dalam melepaskan komponen-komponen alirannya, mengetahui (2) bagaimana sifat temporal persediaan aliran dasarnya, dan (3) bagaimana hubungannya dengan kejadian hujan secara timeseries di daerah tangkapannya. Penelitian ini menggunakan metode survai yang bersifat induktif. Untuk mengetahui karakteristik akuifer dalam melepaskan komponen alirannya, dua alat pencatat fluktuasi muka air SBT dipasang di Mataair Kakap dan mataair Sumbersemen. Pengukuran debit aliran dilakukan untuk memperoleh kurva hubungan debit dan tinggi muka air. Kemudian, dilakukan pemisahan aliran dasar dengan cara digital filtering untuk menghitung besarnya aliran dasar setelah sebelumnya dihitung nilai konstanta resesi aliran diffuse, fissure, dan conduitnya. Sementara itu, untuk mengetahui hubungan hujan dan aliran dua buah penakar hujan otomatis dipasang di dua lokasi tersebut. Analisis yang dilakukan adalah cross-correlation, phase functions, dan cross-amplitude untuk aliran diffuse, fissure, dan conduit. Hasil penelitian menunjukkan bahwa Mataair Kakap mempunyai tiga tipe aliran yaitu diffuse, fissure, dan conduit. Terkait aliran dasar/diffuse/base flow, mataair ini melepaskan komponen diffuse lebih lambat dari pada akuifer karst di Mataair Sumbersemen. Saat musim hujan, Mataair Kakap merespon aliran conduit dari daerah tangkapan dengan cepat, meskipun masih lebih lambat dibanding yang dijumpai di Mataaair Sumbersemen. Dari beberapa hal tersebut dapat disimpulkan bahwa selain memiliki aliran diffuse yang dominan sepanjang tahun (aliran dasar bulanan hampir mencapai nilai 80\%), akuifer di Mataair Kakap telah memiliki jaringan lorong conduit yang berkembang secara lanjut (aliran dasar saat periode banjir kurang dari 40\%). Mataair Sumbersemen hanya memiliki satu tipe aliran dominan yang diimbuh dari akuifer yaitu tipe aliran diffuse (lambat). Saat musim hujan, respon sangat cepat terhadap hujan kemungkinan berasal dari aliran permukaan (bukan dari simpanan conduit). Hal ini dibuktinya dengan sangat kecilnya aliran dasar saat periode banjir dengan nilai $\mathrm{T}_{\mathrm{p}}$ (time to peak) dan $\mathrm{T}_{\mathrm{b}}$ (time to baseflow) yang sangat singkat. Selain itu, simpanan aliran dasar yang sangat tinggi sepanjang tahun (99\%), menunjukkan bahwa kemungkinan aliran dasar berasal dari airtanah dalam dan bukan semata-mata dari lorong diffuse. $\mathrm{T}_{\text {lag }}$ di Mataair Sumbersemen dengan nilai -4 jam menunjukkan waktu yang lebih singkat cepat dibandingkan Mataair Kakap yang memiliki $\mathrm{T}_{\text {lag }} 5$ jam. $\mathrm{T}_{\text {lag }}$ Mataair Sumbersemen yang negatif (-4) menunjukkan bahwa curah hujan memiliki hubungan yang berbanding terbalik dengan debit aliran. Hal ini mengindikasikan bahwa tidak ada hubungan antara debit di Mataair Sumbersemen dan hujan yang jatuh di lokasi penakar hujan. Hal ini mendukung fakta bahwa simpanan aliran dasar di Mataair Sumbersemen berasal dari airtanah dalam.

Kata kunci: akuifer karst, diffuse, fissure, conduit, hujan, aliran dasar 


\section{PRAKATA}

Bismillah,

Laporan akhir ini merupakan bagian dari tahapan Hibah Penelitian Tim Pascasarjana yang berjudul "Model Tingkat Perkembangan Pelorongan Akuifer Karst Untuk Identifikasi Kapasitas Penyerapan Karbon Sebagai Antisipasi Bencana Pemanasan Iklim Global” dengan Surat Kontrak No 254/UN.1.P.III/DITLIT/LT/2017. Penelitian ini direncanakan berlangsung selama 3 (tiga) tahun dan saat ini masih menginjak penelitian pada tahun ke-1 (satu). Penelitian ini telah berlangsung selama 7 bulan dengan tahapan penelitian sudah mencapai progres kemajuan sebesar $100 \%$ (selesai). Obyek penelitian ini adalah mataair karst yang mengambil lokasi kawasan karst (batugamping) di Kabupaten Gunungkidul (DIY) dan di Kabupaten Rembang (Jawa Tengah). Saat ini, peralatan pencatat fluktuasi otomatis tinggi muka air dan penakar hujan telah terpasang di daerah penelitian dan sudah mulai merekan data-data hidrologis yang dibutuhkan untuk mencapai tujuan penelitian tahun ke-1 (satu).

Laporan akhir ini memaparkan hasil penelitian tahun ke-1 (satu) berupa distribusi hidrograf aliran dan data hujan selama periode penelitian, serta telah pula selesai menghitung distribusi konstanta resesi aliran diffuse $\left(\mathrm{K}_{\mathrm{b}}\right)$, konstanta resesi aliran fissure $\left(\mathrm{K}_{\mathrm{i}}\right)$, dan konstanta resesi aliran conduit $\left(\mathrm{K}_{\mathrm{c}}\right)$. Selain itu, sampai laporan akhir ini disusun, telah selesai pula dihitung besarnya aliran dasar secara temporal di daerah penelitian dan hubungannya degan kejadian hujan di daerah tangkapannya. Adapun terkait keluaran (output) penelitian, riset ini telah menghasilkan dua buah artikel ilmiah yang telah dipublikasikan pada dua buah jurnal internasional bereputasi terindeks Scopus dengan impact factor yang cukup tinggi. Selain itu kami telah pula mengirim abstract dan full article untuk mengikuti kegiatan seminar internasional pada bulan November 2017.

Demikianlah pengantar yang dapat kami sampaikan. Dan semoga Allah Subhanahu Wa ta'ala memberi kemudahan pada kami untuk melanjutkan penelitian ini dengan baik pada tahun-tahun mendatang.

Yogyakarta, 10 November 2017

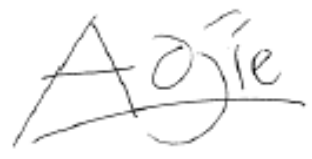

Dr. Tjahyo Nugroho Adji, MSc.Tech

Ketua Peneliti 
DAFTAR ISI

HALAMAN JUDUL

HALAMAN PENGESAHAN 2

RINGKASAN 3

PRAKATA 4

DAFTAR ISI

DAFTAR TABEL 6

DAFTAR GAMBAR 7

DAFTAR LAMPIRAN

BAB 1. PENDAHULUAN 9

BAB 2. TINJAUAN PUSTAKA 15

BAB 3. TUJUAN DAN MANFAAT PENELITIAN 19

BAB 4. METODE PENELITIAN 24

BAB 5. HASIL DAN LUARAN YANG DICAPAI 29

BAB 6. RENCANA TAHAPAN BERIKUTNYA 62

BAB 7. KESIMPULAN DAN SARAN 65

$\begin{array}{lr}\text { DAFTAR PUSTAKA } & 67\end{array}$

LAMPIRAN-LAMPIRAN 


\section{DAFTAR TABEL}

NAMA TABEL

Tabel 3.1. Rencana Target Capaian Tahunan

Tabel 4.1. Peralatan lapangan yang digunakan

Tabel 4.2. Bahan-bahan lapangan yang digunakan

Tabel 4.3. Data Primer Penelitian

Tabel 5.1. Hasil Pengukuran Debit Aliran Mataair Kakap

Tabel 5.2. Konstanta Resesi, $\mathrm{T}_{\mathrm{p}}$ dan $\mathrm{T}_{\mathrm{b}}$ Hidrograf Banjir Terpilih MataairKakap

Tabel. 5.3. Rasio Aliran Dasar dan Total Aliran Tiap Bulan Mataair Kakap

Tabel. 5.4. Rasio Aliran Dasar dan Total Aliran pada Kejadian Banjir Terpilih di Mataair Kakap

Tabel 5.4. Hasil Pengukuran Debit Aliran Mataair Sumbersemen

Tabel 5.5. Konstanta Resesi, $T_{p}$ dan $T_{b}$ Hidrograf Banjir Terpilih Mattair Sumbersemen

Tabel 5.6. Rasio Aliran Dasar dan Total Aliran Tiap Bulan Mataair

Sumbersemen

Tabel. 5.7. Rasio Aliran Dasar dan Total Aliran pada Kejadian Banjir Terpilih Sumbersemen

Tabel 5.8. Kondisi Komponen Aliran Akuifer Karst Atas Dasar Perbandingan Angka Paramater Hidrograf dan aliran dasar

Tabel 5.9. Ringkasan perhitungan time series analysis di Mataair Kakap

Tabel 5.10. Ringkasan perhitungan time series analysis di Mataair Sumbersemen

Tabel 5.11. Ringkasan perhitungan time series analysis di Mataair Kakap dan Sumbersemen
Halaman

23

24

24

24

30

34

36

37

38

41

43

43

44

51

56

56 


\section{DAFTAR GAMBAR}

\section{NAMA GAMBAR}

Gambar 1.1. Jenis lorong diffuse, mixed dan conduit akuifer karst

Gambar 1.2. Persebaran kawasan karst di Provinsi Jateng dan DIY

Gambar 2. 1. Road map riset Karst Research Group, Fakultas Geografi UGM

Gambar 3.1. Detail tujuan penelitian yang dituangkan dalam Work Packages

Gambar 4.1. Diagram Alir Metode Penelitian

Gambar 5.1. Kondisi Aliran Mataair Kakap (kiri) dan Alat Pengukur Tinggi Muka Air yang terpasang

Gambar 5.2. Hubungan Tinggi Muka Air Dan Debit di Mataair Kakap

Gambar 5.3. Variasi Debit Aliran di Mataair Kakap Periode Jan 2016 - Peb 2017

Gambar 5.4. Kejadian Resesi Banjir-Banjir Terpilih Mataair Kakap

Gambar 5.5. Fluktuasi Aliran Dasar Mataair Kakap periode Jan 2016 - Peb 2017

Gambar 5.6. Mataair Sumbersemen

Gambar 5.7. TMA mataair pada kondisi normal (kiri) danTMA mataair pada kondisi banjir

Gambar 5.8. Stage Discharge Rating Curve Mataair Sumbersemen

Gambar 5.9. Pengukuran debit dengan slope area method (kiri) dan download data logger TMA

Gambar 5.10. Hidrograf aliran Mataair Sumbersemen selama periode pengukuran

Gambar 5.11. Kurva Resesi sampel banjir Mataair Sumbersemen

Gambar 5.12. Fluktuasi Aliran Dasar Mataair Kakap

Gambar 5.13. Pasangan data debit aliran dan curah hujan di Mataair Kakap

Gambar 5.14. Cross correlation hubungan debit aliran-curah hujan di Mataair Kakap

Gambar 5.15. Phase functions hubungan debit aliran-curah hujan di Mataair Kakap

Gambar 5.16. Cross-amplitude hubungan debit aliran-curah hujan di Mataair Kakap

Gambar 5.17. Gain functions hubungan debit aliran-curah hujan Mataair Kakap

Gambar 5.18. Auto-correlation hubungan debit aliran-curah hujan di Mataair Kakap

Gambar 5.17. Spectral density hubungan antara debit aliran-curah hujan di Mataair Kakap

Gambar 5.18. Pasangan data debit aliran dan curah hujan di Mataair Sumbersemen

Gambar 5.19. Grafik cross-correlation di Mataair Sumbersemen

Gambar 5.20. Grafik Auto correlation di Mataair Sumbersemen

Gambar 5.21. Grafik spectral density di Mataair Sumbersemen

Gambar 5.12. Grafik cross correlation Mataair Sumbersemen dan Kakap

Gambar 5.13. Grafik auto-correlation Mataair Sumbersemen dan Kakap

Gambar 5.14. Grafik spectral density Mataair Sumbersemen dan Kakap

\section{Hal}


DAFTAR LAMPIRAN

\section{NAMA LAMPIRAN}

\section{Halaman}

Formulir Evaluasi Atas Capaian Luaran Kegiatan

72

Bukti acceptance artikel dan artikel yang yang telah di-publis di jurnal internasional

Bukti submit abstract dan full paper ke seminar internasional dan abstract yang telah di-submit

SK Pembimbing Tim Mahasiswa Pasca Sarjana 


\section{BAB I}

\section{PENDAHULUAN}

\subsection{Latar belakang}

Gas karbondioksida $\left(\mathrm{CO}_{2}\right)$ merupakan salah satu gas rumah kaca yang paling berkontribusi terhadap pemanasan global. Dalam beberapa dekade terakhir, emisi $\mathrm{CO}_{2}$ terus meningkat dan mencapai Giga ton/tahun (Dawson dan Spannagle, 2009; Mackenzie, 2004; Parry, et.al., 2007). Peningkatan emisi ini terutama disebabkan oleh perubahan bahan bakar fosil dan penggunaan lahan. Emisi $\mathrm{CO}_{2}$ dari pembakaran bahan bakar fosil di secara global meningkat dari rata-rata $6,4 \pm 0,4 \mathrm{GtC} /$ tahun pada 1990-an menjadi 7,2 \pm 0,3 GtC tahun pada periode 2000 hingga 2005. Sementara itu, perkiraan emisi $\mathrm{CO}_{2}$ yang terkait dengan perubahan penggunaan lahan, rata-rata selama tahun 1990-an, yang 0,5 sampai 2,7 GtC / tahun, dengan perkiraan pusat sebesar 1,6 Gt / tahun (Parry, et.al., 2007). International Energy Agency (2012) juga telah menyebutkan bahwasanya pembakaran dari bahan bakar fosil yang dilakukan dalam kegiatan industri saat ini telah melepas sekitar 30.276 juta ton per tahun $\mathrm{CO}_{2}$ ke dalam atmosfer pada tahun 2010. Hal ini disebabkan oleh tekanan penduduk di permukaan bumi dengan segala aktivitas antropogenik guna pemenuhan kebutuhannya akan energi dan makanan, sehingga eksploitasi sumberdaya alam berimplikasi terhadap peningkatan konsentrasi gas rumah kaca di atmosfer.

Oleh karena itu, potensi penyerapan karbon secara alami di daratan dan lautan diperlukan untuk menyeimbangkan peningkatan emisi $\mathrm{CO}_{2}$. Bentang alam karst merupakan salah satu ekosistem yang berpotensi menyerap karbon (carbon sink). Sistem yang ada pada bentang alam karst, terutama yang didominasi oleh batuan kapur bermineral kalsit dan dolomit, mencakup sekitar $12 \%$ dari luas daratan di bumi, dan proses pelarutan pada jenis batuan ini pada telah diakui sebagai carbon reservoir yang pada prosesnya selalu menyerap $\mathrm{CO}_{2}$ di atmosfer (Ford dan Williams, 2007; Gornitz, 2008). Kenyataan ini sangat penting, tidak saja hanya karena batuan gamping itu sendiri mengikat karbon, tetapi juga karena proses pelarutan batuan gamping (karstifikasi) itu sendiri adalah proses penyerapan $\mathrm{CO}_{2}$.

Pentingnya proses pelarutan karst (karstifikasi) dalam hal perubahan iklim terletak pada kemampuan ekosistem karst dalam mengatur jumlah karbon di 
atmosfer. Karstifikasi selalu mengkonsumsi $\mathrm{CO}_{2}$ baik yang berasal dari atmosfer dan tanah. Berbeda dengan yang terjadi pada ekosistem lain di mana respirasi $\mathrm{CO}_{2}$ melalui vegetasi dan dekomposisi bahan organik tetap menjadi emisi di atmosfer, maka pada ekosistem karst dapat dikatakan bahwa semua $\mathrm{CO}_{2}$ yang dihasilkan dari respirasi diserap untuk berlangsungnya proses pelarutan. Di ekosistem karst hanya sebagian kecil saja dari $\mathrm{CO}_{2}$ yang diemisikan ke atmosfer pada saat proses pengendapan kalsit atau aragonit selama proses pembentukan ornamen gua (speleothems). Selanjutnya, hampir semua $\mathrm{CO}_{2}$ yang terserap tersebut tersebut dialirkan ke laut dalam bentuk ion bikarbonat $\left(\mathrm{HCO}_{3}{ }^{-}\right)$.

Proses pelarutan batuangamping atau karstifikasi secara ringkas dirumuskan sebagai berikut (Liu dan Zhao, 2000; Grove and Meiman, 2001; Daoxian, 2000)

$$
\mathrm{CaCO}_{3}+\mathrm{CO}_{2}+\mathrm{H}_{2} \mathrm{O} \longrightarrow \mathrm{Ca}^{2+}+2 \mathrm{HCO}_{3}^{-}
$$

Dilihat dari reaksi diatas, keberadaan karbondioksida $\mathrm{CO}_{2}$ memiliki peranan penting dalam proses karstifikasi. $\mathrm{CO}_{2}$ dan air berperan sebagai reaktan untuk membentuk $\mathrm{H}_{2} \mathrm{CO}_{3}$ yang bersifat agresiv untuk melarutkan batuan karbonat. Hal ini menyebabkan besarnya konsentrasi $\mathrm{CO}_{2}$ akan mempengaruhi daya larut batuan karbonat (Haryono dan Adji, 2004). Dengan kata lain, maka semakin tinggi laju pelarutan pada batuan karbonat maka semakin tinggi pula karbondioksida yang terserap. Proses karstifikasi ini terjadi pada satu sistem yang melibatkan interface antara atmosfer, air dan batuan yang dikenal dengan sebutan Karst Dynamic System $(\mathrm{KDS})$.

Istilah Karst Dynamic System yang pertama kali dikenalkan oleh Daoxian (2000) sebenarnya bukan merupakan istilah baru. Bogli (1960, 1980), Sweeting (1972), Trudgill (1985), dan Ford dan Williams (2007), menjelaskan istilah ini sebagai suatu sistem yang di dalamnya terjadi proses yang dinamis antara $\mathrm{H}_{2} \mathrm{O}, \mathrm{CO}_{2}$ dan $\mathrm{CaCO}_{3}$ yang dikontrol oleh karakteristik akuifer batuan gamping. White (1988), Ford dan Williams (2007), Smart dan Hobbes (1986) serta Gillieson (1996) secara prinsip membagi karakteristik jenis pelorongan pada akuifer karst menjadi tiga, yaitu: (a)lorong (conduit); (b)lorong celah (fissure), dan (c)lorong rembesan (diffuse). Sementara itu, Bonacci (1990) menjelaskan bahwa dilihat dari sisi ukurang lorong atau celah yang terbentuk maka terdapat 4 jenis lorong di akuifer karst yaitu lorong 
bertipe (a) intergranular/diffuse $\left(10^{-3}-10^{-1} \mathrm{~mm}\right)$; (b) fractures $\left(10^{-1}-10 \mathrm{~mm}\right)$; (c) fissures $\left(10-10^{2} \mathrm{~mm} \mathrm{~mm}\right)$ and (d) conduits $\left(10^{2}-10^{4} \mathrm{~mm}\right.$--lebih besar). Ilustrasi perkembangan pelorongan pada akuifer karst selanjutnya disajikan pada Gambar 1.1

Selanjutnya, besar kecilnya lorong yang mendominasi akuifer karst tergantung pada intensif atau tidaknya proses karstifikasi yang berlangsung. Atau dengan kata lain, besar kecilnya lorong yang terbentuk tergantung dari besar kecilnya $\mathrm{CO}_{2}$ yang terserap pada proses karstifikasi ini Bogli (1960, 1980), sehingga semakin berkembang pelorongan di akuifer karst, maka semakin pula $\mathrm{CO}_{2}$ yang terserap di akuifer.

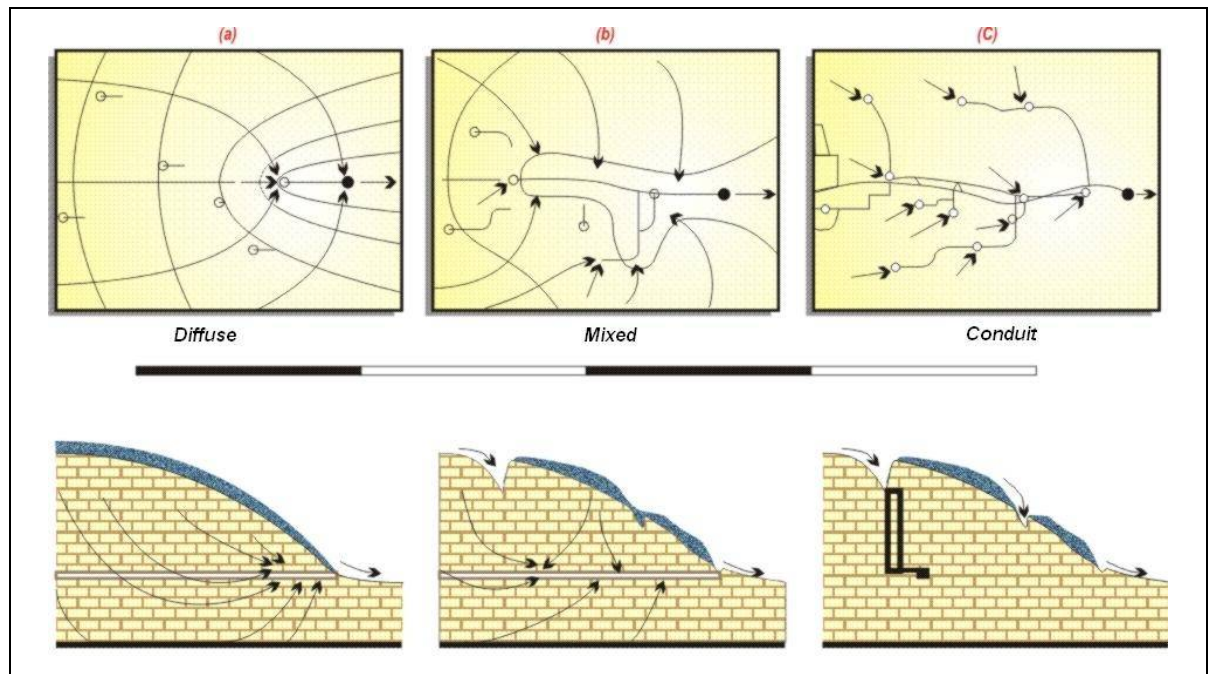

Gambar 1.1. Jenis lorong diffuse, mixed dan conduit akuifer karst (Domenico and

Schwartz, 1990)

Akan tetapi, karena sifat pelorongannya yang anisotropis, maka penelitian untuk mengungkapkan sifat dan karakteristik pelorongan akuifer karst di suatu kawasan umumnya dilakukan dengan pendekatan induktif. Salah satu pendekatan induktif yang dapat digunakan adalah pendekatan hidrogeokimia yang berasumsi bahwa komposisi kimia airtanah karst merupakan cerminan dari proses yang berlangsung dalam akuifer karst (Mudry, 2004). Metode ini dapat dikombinasikan dengan kajian sifat aliran sungai bawah tanah dan merupakan metode yang dianggap paling representatif karena mampu mendeskripsikan sistem media penyimpan airtanah karst, termasuk sifat aliran pada akuifer berbatuan gamping yang berkorelasi dengan sifat kimia airtanah karst, seperti yang dilakukan oleh Liu, et al. (2004a dan 
2004b), Etfimi (2005), Wang, et al. Luo (2001), Anthony, et al. (1997) serta Raeisi dan Karami (1997). Selanjutnya, Martin, et al. (2002) dan Karimi et al. (2004) mengungkapkan bahwa interaksi antara diffuse flow dan conduit flow yang berperan banyak terhadap pelebaran celah pada batuan karbonat, ternyata juga dipicu oleh kadar agresivitas airtanah karst, sedangkan Taylor dan Greene (2001) mengungkapkan bahwa untuk mengkarakterisasi akuifer karst secara detail diperlukan pendekatan kuantitatif.

\subsection{Rumusan Masalah}

Di Provinsi Jawa Tengah dan DIY, terdapat beberapa kawasan karst yang bentuk permukaannya unik serta besarnya sumberdaya air yang ada di dalamnya menjadikan mataair yang keluar dari kawasan-kawasan tersebut menjadi sandara puluhan ribu penduduk yang tinggal di sekitar kawasan-kawasan tersebut. Kawasankawasan tersebut adalah Karst Gunung Sewu (Jateng-DIY), Karst Gombong (Jateng), Karst Jonggrangan (DIY), dan Karst Rembang (Jateng), sebagaimana disajikan pada Gambar 1.2.

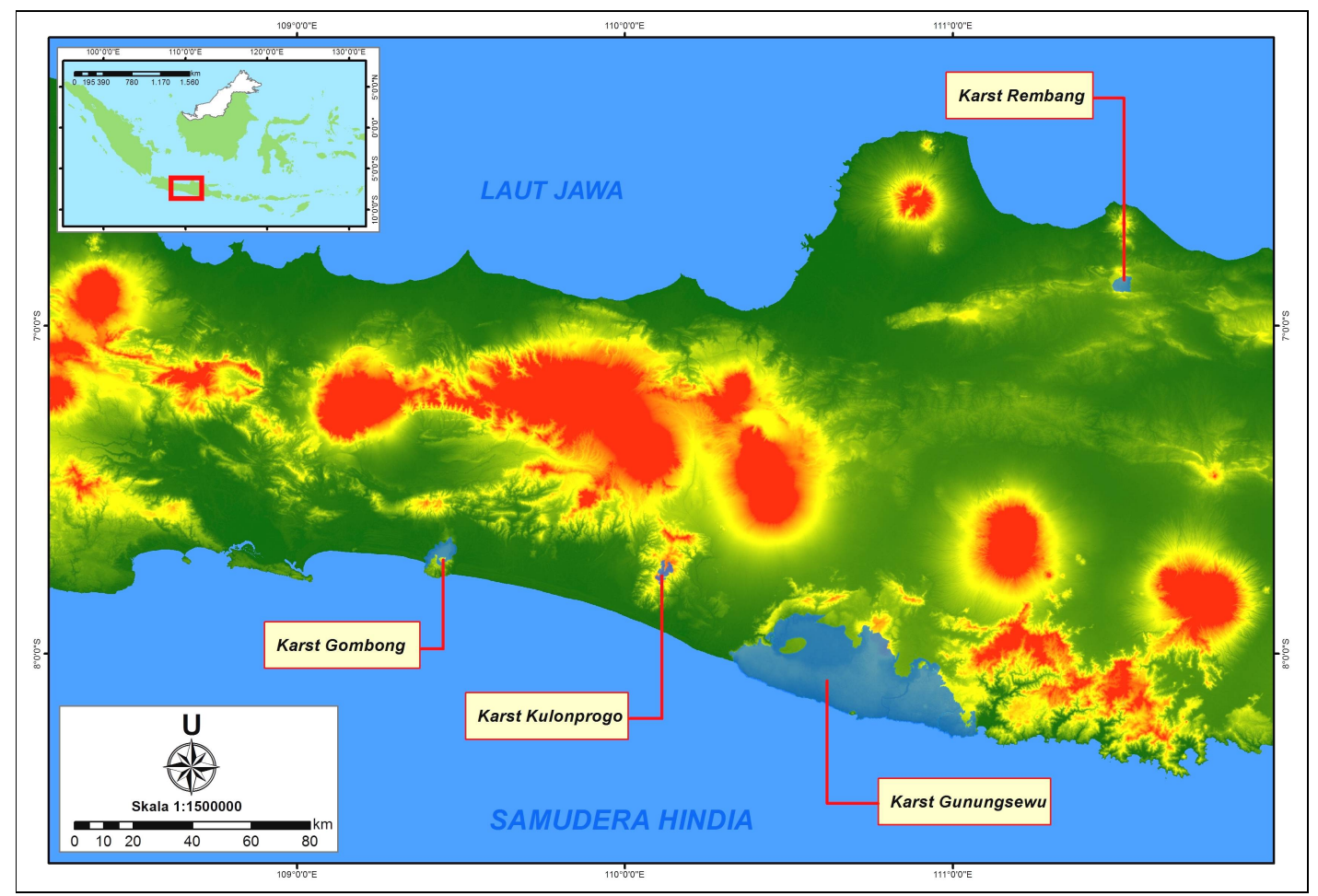

Gambar 1.2. Persebaran kawasan karst di Provinsi Jateng dan DIY 
Di Pulau Jawa, proses tektonik dan pengangkatan batugamping masih terjadi hingga akhir periode tersier (Susilohadi, 1995) sehingga dimungkinkan terdapat perbedaan tingkat perkembangan pelorongan akuifer karst antara satu kawasan karst dan kawasan karst yang lain, sehingga kemampuan untuk menyimpan gas $\mathrm{CO}_{2}$ juga tidak sama. Sebagai contoh adalah indikasi awal perkembangan lorong yang ditunjukkan dengan perbedaan morfologi permukaan yang berbeda antara kawasan karst di bagian utara Pulau Jawa yang berumur Pliosen dan mulai tersingkap sejak akhir Pleistosen, yaitu adalah Karst Rembang, (Noya, et al. 1992; Haryono, et al. 2001; Haryono 2008), dibanding kawasan lain yang berumur lebih tua yaitu Karst Gunungsewu dan Karst Gombong di bagian selatan Pulau Jawa yang berumur Miosen. Berkaitan dengan adanya perbedaan-perbedaan tersebut, sangat menarik untuk diketahui bagaimanakah perkembangan pelorongan pada masing-masing kawasan karst tersebut, dan berapa besar karbon yang dapat terserap pada kawasankawasan tersebut.

Selain itu, pada masa akhir-akhir ini, seiring dengan berkembangnya sektor ekonomi dan bertambahnya kebutuhan semen untuk peningkatan sarana dan prasarana pembangunan, maka kawasan karst (yang menyimpan bahan baku semen utama yaitu batu gamping) sudah diincar oleh kalangan industri semen, sehingga dikhawatirkan akan berkurang pula jumlah gas rumah kaca terutama gas $\mathrm{CO}_{2}$ yang diserap oleh kawasan-kawasan karst tersebut. Maka dari itu perlu segera dilakukan riset untuk mengetahui karakteristik paramater-parameter yang terkait dengan perkembangan pelorongan akuifer karst, siklus gas $\mathrm{CO}_{2}$ di akuifer karst, sehingga dapat diketahui berapa besar kemampuan kawasan-kawasan karst tersebut untuk menyerap gas $\mathrm{CO}_{2}$ sesuai fungsinya sebagai carbon reservoir di wilayah Provinsi Jawa Tengah dan DIY.

Penelitian ini harus segera dilakukan dengan mempertimbangkan beberapa permasalahan yaitu :

1. Bagaimana karakteristik input gas $\mathrm{CO}_{2}$ dari atmosfer berupa hujan secara temporal dan spasial di kawasan karst Jateng-DIY?;

2. Bagaimana karakteristik output gas $\mathrm{CO}_{2}$ _pada debit mataair dan sungai bawah secara temporal dan spasial di kawasan karst JatengDIY?; 
3. Bagaimana karakteristik perkembangan pelorongan akuifer karst atau dasar korelasi antara hujan dan debit mataair dan sungai bawah tanah secara temporal dan spasial di kawasan karst JatengDIY?;

4. Bagaimana karakteristik sifat aliran dari pelorongan karst yang terbentuk secara temporal dan spasial di kawasan karst Jateng-DIY? ;

5. Bagaimanakah karakteristik hidrogeokimia dari pelorongan karst yang terbentuk secara temporal dan spasial di kawasan karst JatengDIY?;

6. Seberapa besar hubungan antara karakteristik aliran dan hidrogeomikia dari pelorongan karst yang berkembang di kawasan karst Jateng-DIY?;

7. Seperti apa distribusi gas $\mathrm{CO}_{2}$ pada zone epikarst yang mengontrol perkembangan pelorongan karst di kawasan karst Jateng-DIY?;

8. Seberapa besar jumlah gas $\mathbf{C O}_{2}$ tahunan dari atmosfer yang terserap pada proses pembentukan lorong akuifer karst di masing-masing kawasan karst Jateng-DIY? 


\section{BAB 2}

\section{TINJAUAN PUSTAKA}

\subsection{State of the Art Bidang yang Diteliti}

Dalam konteks global, sejak dimulai dengan temuan oleh Houghton \& Woodwell (1989) yang menyatakan bahwa kawasan karst di bumi memiliki potensi untuk menyimpan 6,1 x $10^{7}$ milyar ton karbon, di mana nilai tersebut 1694 kali lebih besar daripada kemampuan lautan dan 11 x $10^{5}$ lebih besar daripada kemampuan vegetasi untuk menyerap karbon, maka. Penelitian yang berhubungan dengan karst carbon sequestration telah dilakukan terutama pada dua dekade terakhir ini yaitu oleh Groves and Meiman (2001), Daoxian (2000), Liu \& Zhao (2000), Li, et al. (2008), Han, et al. (2010), Liu, et al (2013), Cortes, et al. (2015), Adji dan cahyadi (2016) dan Huang, et al. (2015). Penelitian terkait penyerapan karbon oleh ekosistem karst ini terus berkembang mengingat semakin dirasakannya pemanasan global akibat peningkatan efek gas rumah kaca di atmosfer yang pada pada era sekarang ini telah dianggap sebagai ancaman bersama bagi kehidupan di bumi. Efek dan kekhawatiran bertambahnya gas rumah kaca di atmosfer inilah yang menjadi pendorong bagi para peneliti di seluruh dunia untuk terus meneliti kemampuan ekosistem karst dlam menyerap gas $\mathrm{CO}_{2}$ dari atmosfer dan tanah.

Sementara itu, dari fakta teoritis yang dikembangkan oleh Bogli $(1960,1980)$ bahwa semakin besar lorong karst yang terbentuk pada proses karstifikasi, maka semakin banyak pula gas $\mathrm{CO}_{2}$ yang diserap, maka metode-metode penelitian untuk mengungkapkan perkembangan akuifer karst telah pula berkembang. Kondisi karstifikasi akuifer seringkali sulit untuk diketahui, sehingga untuk menggambarkan karakteristik, kondisi internal, dan sistem aliran dalam akuifer dapat dianalisis melalui pendekatan hidrogeokimia (Adji 2012, Adji et al. 2015; Liu et al. 2004a) dan juga analisis hidrograf mataair (Bonacci 1993; White 2002; Kresic and Bonacci 2010; Mohammadi and Shoja, 2013; Quinlan 1989; Quinland et al. 1991). Pada masa beberapa tahun terakhir, analisis kurva resesi juga dilakukan untuk menentukan tingkat karstifikasi akuifer karst berdasarkan koefisien resesi sub rezim debit alirannya (Malik 2007; Malik and Vojtkova 2010, 2012) dan berdasarkan analisis seluruh komponen hidrograf (Rashed, 2012). Selain itu analisis deret waktu di 
akuifer karst juga telah dilakukan (Padilla and Pulido-Bosch 1995; Eisenlohr et al. 1997; Larocque et al. 1998; Rahnemaei et al. 2005; Panagopoulos and Lambrakis 2006; Valdes et al. 2006; Fiorillo and Doglioni 2010; Zhang et al. 2013, Adji and Bahtiar 2016).

\subsection{Penelitian Terdahulu}

Penelitian mengenai perkembangan akuifer oleh proses karstifikasi akan menghasilkan model perkembangan lrong pada beberapa kawasan karst. Sementara itu, perhitungan karbon yang diserap pada masing-masing kawasan karst tergantung dari level perkembangan lorong yangterjadi pada akuifer karst. Penelitian yang menunjang dan berkaitan dengan hal tersebut telah lama dilakukan oleh Karst Research Group, Fakultas Geografi UGM yaitu sejak tahun 1993. Berbagai pengalaman penelitian dan penelitian dari pihak-pihak lain tentang perkembangan akuifer karst dan model penyerapan karbon yang menunjang penelitian yang akan dilakukan ini adalah sebagai berikut:

1. Adji T.N., Bahtiar I.Y., 2016, Rainfall-discharge relationship and karst flow components analysis for karst aquifer characterization in Petoyan Spring, Java, Indonesia, Environmental Earth Sciences, 75:73. Penelitian ini mengungkapkan adanya hubungan signal input hujan dan output debit mataair dengan korelasi yang signifikan;

2. Adji T.N., Haryono E., Fatchurrohman, H., Oktama, R., 2015, Diffuse flow characteristics and their relation to hydrochemistry conditions in the Petoyan Spring, Gunungsewu Karst, Java, Indonesia. Geosciences Journal. DOI 10.1007/s12303-015-0048-8, (online first - In press). Penelitian ini menemukan bahwa salah satu proses yang berpengaruh terhadap perkembangan lorong di akuifer karst adalah water-rock interaction;

3. Adji T.N., 2013, Hydrogeochemistry and Karst Flow Properties of Bribin River Indonesia, LAP LAMBERT Academic Publishing, Saarbrücken, Germany, 244 p. Penelitian ini menjadi penelitian pertama dalam bidang survai hidrologi detail di Indonesia yang menggunakan dua parameter yaitu hidrokimia dan sifat aliran;

4. Adji T.N., 2012, Wet season hydrochemistry of Bribin River in Gunung Sewu Karst, Indonesia. Environmental Earth Sciences, 76, 1563-1572. Penelitian ini menemukan bahwa secara temporal proses perkembangan lorong karst ditentukan oleh beberapa proses terkait berubahnya parameter KDS di ekosistem karst;

5. Fatchurohman, H., Adji, T.N., 2014, Study of Water-Rock Interaction to Characterize Karst Aquifer In Ngeleng Spring, The 6th Indonesia Japan Joint Scientific Symposium, Yogyakarta 28-30 Oktober 2014. Penelitian ini menemukan bahwa proses yang dominan pada aliran yang seragam adalah water-rock interaction;

6. Adji, T.N., 2011, Pemisahan aliran dasar (diffuse flow) hulu daerah tangkapan hujan Sungai Bribin pada aliran Gua Gilap, Karst Gunung Sewu, Gunung Kidul, Yogyakarta, Jurnal Geologi Indonesia, Vol 6, No.3, Sept. 2011. Hasil penelitian ini 
menemukan bahwa dominasi aliran dasar tetap terjaga sepanjang tahun di hulu SBT Bribin;

7. Adji, T.N., 2011, Upper Catchment olu SBT of Bribin Underground River Hydrogeochemistry (Gunung Sewu Karst, Java, Indonesia), Proceeding of Asian Trans-Disciplinary Karst Conference, Jogjakarta, 2011. Penelitian ini mengupas tentang berbagai macam proses hidrogeokimia yang mempengaruhi perkembangan lorong karst baik secara spasial dan temporal;

8. Brunsch, A., Adji, T.N., Ikhwan, M., Stoffel, D., Oberle, P. And Nestmann, F., 2011, Hydrological assessment of a karst area in Southern Java with respect to climate phenomena. Proceedings of Asian Trans-Disciplinary Karst Conference 2011, Jogjakarta, January 7-10, p. 55-68. Penelitian ini mengungkapkan distribusi spasial dan temporal hujan yang terjadi di kawasan karst Gunung Sewu;

9. Adji T.N., Misqi M., 2010, The Distribution of Flood Hydrograph Recession Constant for Characterization of Karst Spring and Underground River Flow Components Releasing Within Gunung Sewu Karst Region, Indonesia, Indonesian Journal of Geography, XLII(1), 1-12. Penelitian ini berhasil membedakan sifat akuifer dalam melepaskan air pada beberapa lokasi;

10. Adji, T.N., Rahmawati, N., 2010, The Contribution of $\mathrm{CO}_{2}$ Content in Rainfall to Dissolution Process in Karst Area (Case Study In Bribin Underground River), The Proceeding of Technology cooperation and economic benefit of reduction of GHG emissions in Indonesia" held on 1-2 November 2010 in Hamburg. Penelitian ini mendeskripsikan bahwa besar kecilnya gas $\mathrm{CO}_{2}$ berpengaruh terhadap proses pembentukan ornamen gua;

11. Hariadi, B., Adji, T.N., 2009, Variasi Temporal Hidrogeokimia Tetesan dari Ornamen Drapery di dalam Gua Gilap di Kawasan Karst Gunungsewu, Kabupaten Gunungkidul, DIY, Gunung Sewu-Indonesian Cave and Karst Journal, Vol 5 No 1, April 2009. Penelitian ini juga mengungkapkan bahwa besar kecilnya gas $\mathrm{CO}_{2}$ dikontrol oleh musim dan sifat lorong pada akuifer;

12. Haryono, E. Adji, T.N., Widyastuti, M., Putro, S.T., 2009, Atmospheric Carbon Dioxide Sequestration Trough Karst Denudation Process, Preliminary Estimation From Gunung Sewu Karst, International Seminar on Achieving Resilient-Agriculture to Climate Change Through the Development of Climate-Based Risk Management Scheme, PERHIMPI, Bogor 17-19 Desember 2009. Penelitian ini dengan menggunakan model yang sederhana menghitung besarnya gas $\mathrm{CO}_{2} /$ tahun yang diserap di kawasan karst Gunung Sewu.

\subsection{Road map penelitian yang dilaksanakan}

Penelitian yang mendukung topik perkembangan akuifer karst dan serapan $\mathrm{CO}_{2}$ di akuifer karst, telah dilakukan oleh Karst Research Group, Fakultas Geografi UGM yaitu sejak tahun 1993. Beberapa penelitian tersebut didanai oleh pemerintah dengan skema Hibah, dan sebagian lagi merupakan kerjasama yang diikat dengan MoU dengan beberapa institusi di antaranya adalah program Integrated Water Resources Management (IWRM) dengan Univesitas Karslruhe (Germany) dan program Carbon Capture in karst dengan IRCK, Guilin, China. 
Penelitian-penelitian tersebut secara umum telah menghasilkan karakteristik perkembangan akuifer karst di sebagian kawasan di Pulau Jawa dan mendefinisikan bagaimana proses penyerapan gas $\mathrm{CO}_{2}$ pada akuifer karst. Penelitian-penelitian tersebut telah dipublikasikan baik pada jurnal-jurnal internasional bereputasi tinggi, seminar internasional, serta pertemuan-pertemuan ilmiah tingkat nasional. Secara detail, Keterkaitan road map penelitian terdahulu dan tujuan dari penelitian ini disajikan pada Gambar 2. 1.

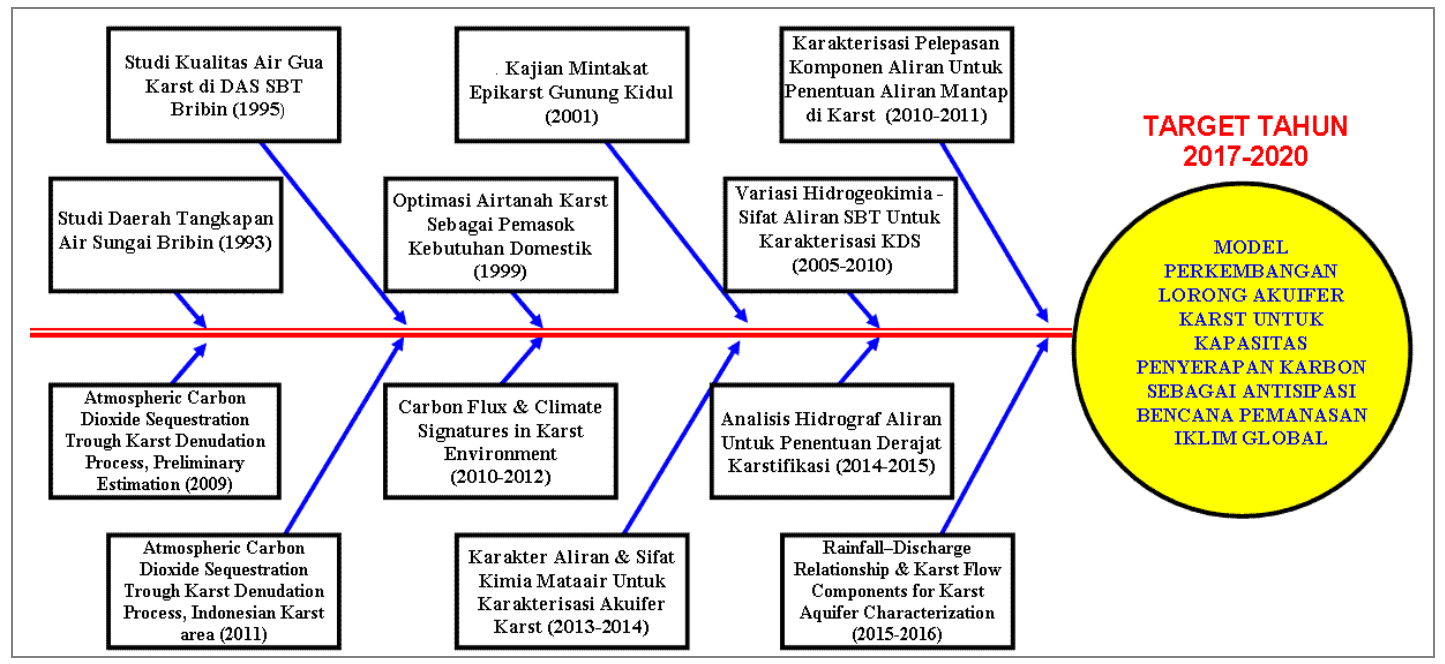

Gambar 2. 1. Road map riset Karst Research Group, Fakultas Geografi UGM 


\section{BAB III \\ TUJUAN DAN MANFAAT PENELITIAN}

\subsection{Tujuan Khusus Penelitian}

Secara umum kajian ini bertujuan untuk mendefiniskan tahapan perkembangan pelorongan akuifer karst pada beberapa kawasan karst di Provinsi Jateng-DIY untuk menghitung berapa besar kapasitas carbon reservoir pada masing-masing kawasan tersebut. Selanjutnya, secara spesifik tujuan dari penelitian ini dirinci menjadi 3 tahapan sesuai dengan tahun pelaksanaan. Tujuan khusus dari penelitian ini adalah sebagai berikut:

\section{7. . Tujuan Tahun Pertama}

Tujuan tahun pertama dari penelitian ini meliputi:

1) Menjelaskan karakteristik dan menghitung input gas $\mathrm{CO}_{2} \underline{\text { dari atmosfer berupa }}$ hujan secara temporal dan spasial di kawasan karst Jateng-DIY? ;

2) Menjelaskan karakteristik dan menghitung output gas $\mathrm{CO}_{2}$ pada debit mataair dan sungai bawah secara temporal dan spasial di kawasan karst Jateng-DIY?;

3) Mendefinisikan karakteristik perkembangan pelorongan akuifer karst atas dasar korelasi antara hujan dan debit mataair dan sungai bawah tanah secara temporal dan spasial di kawasan karst Jateng-DIY?.

\section{B. Tujuan Tahun Kedua}

Tujuan tahun kedua penelitian ini meliputi:

1) Menjelaskan karakteristik sifat aliran dari pelorongan karst yang terbentuk secara temporal dan spasial di kawasan karst Jateng-DIY?;

2) Mendefinisikan karakteristik hidrogeokimia dari pelorongan karst yang terbentuk secara temporal dan spasial di kawasan karst Jateng-DIY? ;

3) Menghitung dan menjelaskan seberapa besar hubungan antara karakteristik aliran dan hidrogeomikia dari pelorongan karst yang berkembang di kawasan karst Jateng-DIY?.

7. . $\quad$ Tujuan Tahun Ketiga

Tujuan tahun ketiga dari penelitian ini terdiri dari: 
1. Mendeskripsikan distribusi gas $\mathrm{CO}_{2}$ pada zone epikarst yang mengontrol perkembangan pelorongan karst di kawasan karst Jateng-DIY?;

2. Menentukan derajat karstifikasi dan menghitung seberapa besar jumlah gas $\mathbf{C O}_{2}$ tahunan dari atmosfer yang terserap pada proses pembentukan lorong akuifer karst di masing-masing kawasan karst Jateng-DIY?

Selanjutnya, detail tujuan khusus penelitian dituangkan pada Gambar 3.1.

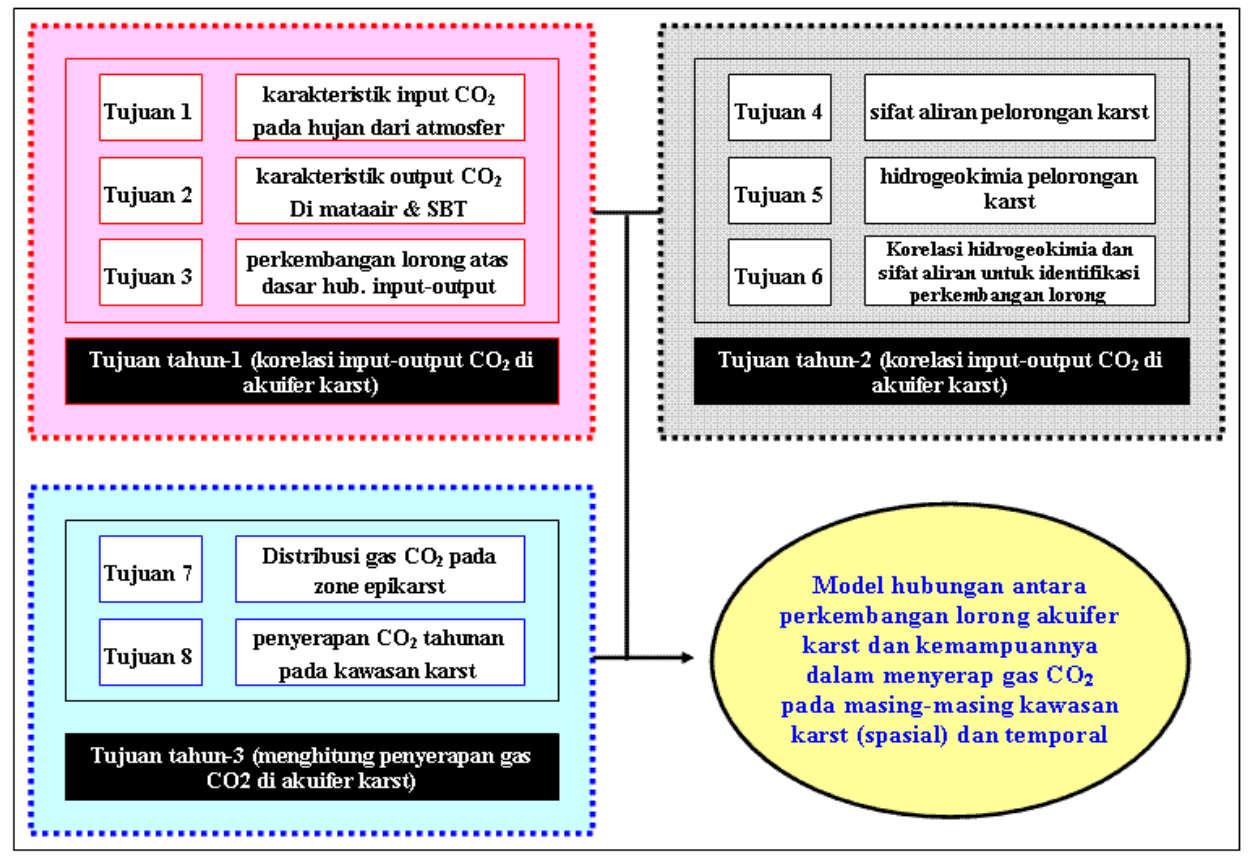

Gambar 3.1. Detail tujuan penelitian yang dituangkan dalam Work Packages

\subsection{Manfaat Penelitian}

\subsubsection{Signifikansi Penelitian}

Houghton \& Woodwell (1989) telah menyebutkan bahwa kawasan karst di bumi memiliki potensi untuk menyimpan 6,1 x 107 milyar ton karbon, di mana nilai tersebut 1694 kali lebih besar daripada kemampuan lautan dan 11 x $10^{5}$ lebih besar daripada kemampuan vegetasi dalam hal kemampuannya menyerap karbon. Sementara itu, proses pembentukan karst (kartifikasi) yang membentuk lorong-lorong selalu membutuhkan serapan gas $\mathrm{CO}_{2}$ baik dari udara atau tanah selama 24 jam terus menerus. Semakin besar lorong karst yang terbentuk, maka semakin banyak pula gas $\mathrm{CO}_{2}$ yang diserap. Oleh karena itu, kajian model perkembangan lorong akuifer karst pada beberapa kawasan karst sangat penting untuk dilakukan, dalam rangka mencari hubungannya dengan proses penyerapan gas $\mathrm{CO}_{2}$, yang sangat berarti 
untuk mengurangi jumlah gas rumah kaca di atmosfer. Lebih jauh lagi, model hubungan antara perkembangan lorong dan peyerapan gas $\mathrm{CO}_{2}$ secara signifikan akan membantu pengungkapan sistem karst di kawasan lain yang tersebar banyak dan merata di Indonesia.

Selain itu, mengingat mulai timbulnya konflik antara konservasi vs. Pemanfaatan kawasan karst pada masa akhir-akhir ini, terutama alih fungsi lahan ekosistem karst menjadi industri batugamping (semen), yang jika hal tersebut tidak segera diantisipasi, akan berpotensi mengurangi gas $\mathrm{CO}_{2}$ yang terserap oleh ekosistem karst. Maka dari itu, perlu segera dilakukan riset untuk mengetahui detail karakteristik paramater-parameter yang terkait dengan perkembangan pelorongan akuifer karst, siklus gas $\mathrm{CO}_{2}$ di akuifer karst, serta berapa besar kemampuan kawasan-kawasan karst di wilayah Provinsi Jawa Tengah dan DIY untuk menyerap gas $\mathrm{CO}_{2}$ _(carbon reservoir), sehingga dapat secara signifikan menjadi penengah atau pertimbangan untuk pengambilan keputusan bagi pihak pemerintah dalam mengatasi konflik antar kepentingan yang terjadi pada kawasan karst.

\subsubsection{Status penelitian ini dalam konteks global}

Topik mengenai peningkatan konsentrasi gas rumah kaca di atmosfer hingga saat ini terus menjadi perbincangan yang esensial dalam skala multinasional, terlebih lagi dengan diberlakukanya SDGs (Sustainable Development Goals) yang menggantikan MDGs (Millenium Development Goals) pada tahun mendatang. Peningkatan konsentrasi gas rumah kaca terutama $\mathrm{CO}_{2}$ di atmosfer erat kaitanya dengan penyebab terjadinya global warming dan perubahan iklim. Sementara itu proses pada ekosistem karst merupakan bagian dari siklus karbon dunia, air dan kalsium yang terjadi pada antarmuka antara litosfer, hidrosfer, atmosfer dan biosfer. Reaksi $\mathrm{CO}_{2}$ $\mathrm{H}_{2} \mathrm{O}-\mathrm{CaCO}_{3}$ adalah karst sistem dinamis yang berguna dalam menjelaskan pentingnya karst dalam siklus karbon (Daoxian, 2000; Grove, 2001; Liu dan Zhao, 2000). Penelitian selanjutnya karst memiliki peran penting dalam memahami siklus karbon global, dan dengan demikian dapat memberikan kontribusi lebih untuk memahami perubahan iklim global.

\subsection{Kontribusi terhadap ilmu pengetahuan}

Terhadap ilmu pengetahuan, penelitian ini akan memberikan kontribusi nyata terkait metode baru untuk membuat model perkembangan lorong di akuifer karst. Selama ini metode untuk menentukan perkembangan akuifer karst terpaku pada sebagaimana yang disampaikan oleh Rashed (2012), yaitu metode hydrochemograph analysis (Shuster and White, 1971); metode 
kernel functions analysis (Dreiss, 1989); metode ratio of heterogeneity (Karami and Younger, 2002); metode recession constant analysis (Ford and Williams, 2007); dan metode aquifer flashiness (Delleur, 1999). Adapun penelitian ini akan melakukan sedikit modifikasi dan tambahan parameter pada beberapa metode di atas, yaitu dengan melakukan analisis korelasi antara hujan sebagi signal input dan debit mataair dan sungai bawah tanah sebagai signal output dan juga melakukan analisis hubungan antara karakteristik aliran dan hidrogeomikia untuk mengetahui tingkat perkembangan pelorongan karst.

Dari sisi penyerapan karbon (carbon sequstration), selama ini belum ada penelitian yang menghubungkan antara tingkat perkembangan lorong dan kapasitas penyerapan karbon oleh akuifer karst. Pada sifat penelitian yang spasial dan temporal, maka penelitian ini berkontribusi mendetailkan perbedaan sifat penyerapan karbon pada beberapa kawasan yang berbeda dan pada musim yang berbeda, sehingga akan memperkaya penelitian-penelitian sejenis, sebagaimana yang telah dilakukan oleh Li, et al. (2008), Han, et al. (2010), Liu, et al (2013), Cortes, et al. (2015), dan Huang, et al. (2015).

\subsection{Capaian yang ditargetkan}

Rencana capaian yang ditargetkan selama penelitian ini berjalan yaitu selama 3 (tahun) di antaranya adalah 4 publikasi ilmiah jurnal terakreditasi nasional dan internasional bereputasi tinggi, pemakalah dalam temu ilmiah berskala nasional dan internasional, invited speaker, visiting lecture, model pengelolaan karst, buku ajar dan buku teks. Secara rinci pencapaian tersebut disajikan pada Tabel 3.1. 
Tabel 3.1. Rencana Target Capaian Tahunan

\begin{tabular}{|c|c|c|c|c|c|}
\hline \multirow{2}{*}{ No } & \multicolumn{2}{|l|}{ Jenis Luaran } & \multicolumn{3}{|c|}{ Indikator Capaian } \\
\hline & & & TS & TS+1 & TS+2 \\
\hline \multirow[b]{2}{*}{1} & \multirow{2}{*}{ Publikasi ilmiah $^{2)}$} & Internasional & submitted & published & published \\
\hline & & Nasional Terakreditasi & submitted & published & published \\
\hline \multirow[t]{2}{*}{2} & \multirow[t]{2}{*}{ Pemakalah dalam temu ilmiah } & Internasional & terdaftar & Sudah dilaksanakan & Sudah dilaksanakan \\
\hline & & Nasional & - & Sudah dilaksanakan & Sudah dilaksanakan \\
\hline \multirow[b]{2}{*}{3} & \multirow{2}{*}{$\begin{array}{l}\text { Invited speaker dalam temu } \\
\text { ilmiah }^{4)}\end{array}$} & Internasional & & terdaftar & Sudah dilaksanakan \\
\hline & & Nasional & & terdaftar & Sudah dilaksanakan \\
\hline 4 & Visiting Lecturer $^{5)}$ & Internasional & & terdaftar & Sudah dilaksanakan \\
\hline \multirow{9}{*}{5} & \multirow{9}{*}{$\begin{array}{l}\text { Hak Kekayaan Intelektual } \\
(\mathrm{HKI})^{6)}\end{array}$} & Paten & & & \\
\hline & & Paten sederhana & & & \\
\hline & & Hak Cipta & & & \\
\hline & & Merek dagang & & & \\
\hline & & Rahasia dagang & & & \\
\hline & & Desain Produk Industri & & & \\
\hline & & Indikasi Geografis & & & \\
\hline & & $\begin{array}{l}\text { Perlindungan Varietas } \\
\text { Tanaman }\end{array}$ & & & \\
\hline & & $\begin{array}{l}\text { Perlindungan Topografi } \\
\text { Sirkuit } \\
\text { Terpadu }\end{array}$ & & & \\
\hline 6 & \multicolumn{2}{|l|}{ Teknologi Tepat Guna $^{7)}$} & & & \\
\hline 7 & \multicolumn{2}{|c|}{ Model/Purwarupa/Desain/Karya seni/ Rekayasa Sosial ${ }^{8)}$} & & & draft \\
\hline 8 & \multicolumn{2}{|l|}{ Buku Ajar (ISBN) ${ }^{9)}$} & & draft & editing \\
\hline 9 & \multicolumn{2}{|c|}{ Tingkat Kesiapan Teknologi (TKT) ${ }^{10)}$} & Tingkat-1 & Tingkat-1 & Tingkat-1 \\
\hline
\end{tabular}




\section{BAB 4 \\ METODE PENELITIAN}

\subsection{Alat, bahan, dan data primer}

Peralatan yang digunakan pada penelitian ini disajikan pada Tabel 4.1.

Tabel 4.1. Peralatan lapangan yang digunakan

\begin{tabular}{|c|l|l|}
\hline No & \multicolumn{1}{|c|}{ Nama alat } & \multicolumn{1}{c|}{ Fungsi } \\
\hline 1 & Stereoskop cermin & Interpretasi foto udara \\
\hline 2 & Notebook/komputer & Download data hujan dan aliran \\
\hline 3 & Hobo Water Level Data Logger & Mencatat fluktuasi tinggi muka air \\
\hline 4 & Mini Station Data Logger & $\begin{array}{l}\text { Mencatat data hujan, suhu, kelembaban, dan tekanan } \\
\text { udara }\end{array}$ \\
\hline 5 & Single Rope Techniques (SRT) set & Masuk ke gua vertikal \\
\hline 6 & Global Positioning System (GPS) & Menentukan posisi di lapangan \\
\hline 7 & Botol sampel (20 buah) & $\begin{array}{l}\text { Mengambil sampel air sungai bawah tanah, tetesan gua, } \\
\text { mataair, dan hujan }\end{array}$ \\
\hline 8 & Electrical Conductivity & Mengukur daya hantar listrik air \\
\hline 9 & pH meter & Mengukur derajat keasaman air \\
\hline 10 & Penakar hujan otomatis & Mencatat data hujan \\
\hline 11 & Meteran & Mengukur tinggi muka air \\
\hline 12 & Current meter & Menghitung kecepatan aliran \\
\hline 13 & Fluorometer & Melacak sistem sungai bawah tanah \\
\hline
\end{tabular}

Bahan yang digunakan pada penelitian ini disajikan pada Tabel 4.2.

Tabel 4.2. Bahan-bahan lapangan yang digunakan

\begin{tabular}{|c|l|l|}
\hline No & \multicolumn{1}{|c|}{ Nama bahan } & \multicolumn{1}{c|}{ Fungsi } \\
\hline 1 & $\begin{array}{l}\text { Peta Rupa Bumi (RBI) daerah } \\
\text { penelitian skala 1:25.000,- }\end{array}$ & Delinasi dan interpretasi kawasan karst \\
\hline 2 & Foto udara B/W & Delinasi dan interpretasi kawasan karst \\
\hline 3 & Citra satelit & Delinasi dan interpretasi kawasan karst \\
\hline 4 & Alkalinity test kit & Mengukur kalsium dan bikarbonat di lapangan \\
\hline 5 & Standard limestone tablet & Mengukur tingkat pelarutan tanah \\
\hline 6 & Tinopal CBS-X & Melacak sistem sungai bawah tanah \\
\hline 7 & Uranine & Melacak sistem sungai bawah tanah \\
\hline
\end{tabular}

Tabel 4.3. Data Primer Penelitian

\begin{tabular}{|l|l|l|l|}
\hline No & \multicolumn{1}{|c|}{ Jenis Data } & \multicolumn{1}{|c|}{ Parameter } & \multicolumn{1}{|c|}{$\begin{array}{c}\text { Sumber dan Cara } \\
\text { Pengambilan Data }\end{array}$} \\
\hline \multirow{2}{*}{$\begin{array}{l}\text { Hidrokimia Air Sungai Bawah } \\
\text { Tanah, dan Mataair }\end{array}$} & $\begin{array}{l}\mathrm{Ca}^{2+}, \mathrm{Mg}^{2+}, \mathrm{Na}^{+}, \mathrm{K}^{+}, \mathrm{Cl}^{-}, \\
\mathrm{SO}_{4}^{2-}, \mathrm{dan}_{\mathrm{HCO}}^{-} \cdot \mathrm{pH}, \mathrm{DHL}, \\
\mathrm{Suhu}^{2+}\end{array}$ & $\begin{array}{l}\text { Pengukuran lapangan } \\
\text { dan laboratorium }\end{array}$ \\
\hline 2 & $\begin{array}{l}\text { Hidrokimia Air Tetesan Ornamen } \\
\text { Gua }\end{array}$ & $\begin{array}{l}\mathrm{Ca}^{2+}, \mathrm{Mg}^{2+}, \mathrm{Na}^{+}, \mathrm{K}^{+}, \mathrm{Cl}^{-}, \\
\mathrm{SO}_{4}^{2-}, \mathrm{dan}_{\mathrm{HCO}_{3}^{-}}, \mathrm{pH}, \mathrm{DHL},\end{array}$ & $\begin{array}{l}\text { Pengukuran lapangan } \\
\text { dan laboratorium }\end{array}$ \\
\hline
\end{tabular}




\begin{tabular}{|l|l|l|l|}
\hline & \multicolumn{1}{|c|}{ Suhu } & \\
\hline 3 & Data curah hujan 1 tahun & Tebal hujan, durasi, intensitas & $\begin{array}{l}\text { Pemasangan alat dan } \\
\text { pencatatan data hujan }\end{array}$ \\
\hline 4 & Data Iklim 1 tahun & $\begin{array}{l}\text { Kelembaban, suhu, tekanan } \\
\text { udara }\end{array}$ & $\begin{array}{l}\text { Pemasangan alat dan } \\
\text { pencatatan data }\end{array}$ \\
\hline 4 & Hidrokimia Air Hujan & $\begin{array}{l}\mathrm{Ca}^{2+}, \mathrm{Mg}^{2+}, \mathrm{Na}^{+}, \mathrm{K}^{+}, \mathrm{Cl}^{-}, \\
\mathrm{SO}_{4}^{2-}, \text { dan } \mathrm{HCO}_{3}^{-} \cdot \mathrm{pH}, \mathrm{DHL}, \\
\mathrm{Suhu}^{2}\end{array}$ & $\begin{array}{l}\text { Pengukuran lapangan } \\
\text { dan laboratorium }\end{array}$ \\
\hline 5 & $\begin{array}{l}\text { Fluktuasi tahunan tinggi muka } \\
\text { airtanah dan debit Sungai Bawah } \\
\text { Tanah }\end{array}$ & $\begin{array}{l}\text { Tinggi muka air dalam satuan } \\
\text { meter }(\mathrm{m}), \text { dan debit aliran } \\
\text { dalam satuan lt/dt }\end{array}$ & $\begin{array}{l}\text { Pengukuran dan } \\
\text { pencatatan lapangan }\end{array}$ \\
\hline 6 & $\begin{array}{l}\text { Fluktuasi tahunan intesitas tetesan } \\
\text { ornamen gua }\end{array}$ & $\begin{array}{l}\text { Intensitas dalam ml/menit } \\
\text { pencatatan lapangan }\end{array}$ \\
\hline 7 & $\begin{array}{l}\text { Jaringan sungai bawah tanah } \\
\text { Asal, arah dan keluaran } \\
\text { bahan pelacak }\end{array}$ & $\begin{array}{l}\text { Pengukuran lapangan } \\
\text { dan interpretasi }\end{array}$ \\
\hline 8 & $\begin{array}{l}\text { Distribusi karbondioksida dalam } \\
\text { tanah }\end{array}$ & $\begin{array}{l}\text { Pengurangan berat standard } \\
\text { limestone tablet }\end{array}$ & $\begin{array}{l}\text { Pengukuran lapangan } \\
\text { dan interpretasi }\end{array}$ \\
\hline
\end{tabular}

\subsection{Metode penelitian}

\subsubsection{Metode penelitian tahun pertama}

Penelitian pada tahun ke-1 mempunyai 3 tujuan dengan langkah-langkah sebagai berikut:

- Pemasangan alat pencatat curah hujan dan pencatatan data hujan;

- Pemasangan water level data logger) untuk pencatatan TMA;

- Pengukuran kecepatan aliran dan penampang basah pada semua lokasi yang dipasang alat pencatat TMA pada saat debit puncak, debit menengah, dan debit minimum untuk keperluan pembuatan Stage Discharge Rating Curve dengan melakukan analisis regresi (Schulz, 1976).

- Melakukan uji korelasi silang (Cross Correlation) hubungan series data $x$ (input) hujan dengan data y (output) debit. Hubungan kedua variabel tersebut didefinisikan dalam rumus (Cowpertwait dan Metcalfe, 2009, Shumway dan Stoffer, 2006, dalam Thomas, 2010):

$$
r_{x y}(k)=\frac{C x y(k)}{\sqrt{C_{x}^{2}(0) C_{y}^{2}(0)}}
$$

\subsubsection{Metode penelitian tahun kedua}

Penelitian pada tahun ke-2 mempunyai 3 tujuan dengan langkah-langkah:

- Pengambilan sampel air dengan intensitas yang rapat untuk mengkarakterisasi dinamika SKD; 
- Pengambilan sampel air hujan untuk uji kualitas air di daerah tangkapan hujan;

- Pengukuran alkalinity, pH, suhu, Daya Hantar Listrik (DHL), dan Eh lapangan;

- Menghitung konstanta resesi dari kurva resesi dengan rumus :

$$
Q_{t}=Q_{0} e^{-\alpha t}
$$

(dimana $Q_{t}$ is adalah debit aliran pada waktu $t, Q_{0}$ adalah debit awal pada segmen resesi, dan $\alpha$ adalah suatu konstanta)

- Analisis pemisahan aliran dasar (baseflow separation) dengan automated base flow separation by digital filtering method (Eckhardt, 2005), rumus yang digunakan adalah :

$$
q_{b(i)}=\frac{\left(1-B F I_{\text {max }}\right) a q_{b(i-1)}+(1-a) B F I_{\text {max }} q_{i}}{1-a B F I_{\text {max }}}
$$

(dimana $q_{b(i)}$ adalah baseflow pada saat $i, q_{b(i-1)}$ adalah baseflow pada waktu sebelumnya $i-1, q_{i}$ adalah total aliran pada waktu $i$, a adalah konstanta resesi dan $B F I_{\text {max }}$ adalah baseflow maksimum yang dapat diukur atau diketahui

- Analisis kimia sampel di laboratorium meliputi kation $\mathrm{Ca}^{2+}, \mathrm{Mg}^{2+}, \mathrm{Na}^{+}, \mathrm{K}^{+}$, dan anion $\mathrm{Cl}^{-}$, $\mathrm{SO}_{4}{ }^{2-}$, dan $\mathrm{HCO}_{3}{ }^{-}$. Metode analisis yang digunakan meliputi : metode volumetri untuk unsur $\mathrm{Ca}^{2+}, \mathrm{Mg}^{2+}, \mathrm{CO}_{3}^{-}$dan $\mathrm{SO}_{4}{ }^{2-}$; metode spektrofotometri untuk unsur $\mathrm{HCO}_{3}^{-}$; metode flamefotometri untuk unsur $\mathrm{Na}^{+}$dan $\mathrm{K}^{+}$.

- Analisis Charge Balance Calculation, dengan rumus :

$$
\begin{array}{r}
\left(\mathrm{Na}^{+}\right)+\left(\mathrm{K}^{+}\right)+2\left(\mathrm{Ca}^{2+}\right)+2\left(\mathrm{Mg}^{2+}\right)=\left(\mathrm{Cl}^{-}\right)+\left(\mathrm{HCO}_{3}{ }^{-}\right)+2\left(\mathrm{SO}_{4}{ }^{2-}\right) \text { sehingga : } \\
\sum z m c=\sum z m a \ldots \ldots \ldots \ldots \ldots \ldots \ldots \ldots \ldots \ldots \ldots \ldots \ldots \ldots \ldots \ldots \ldots \ldots \ldots \ldots \ldots \ldots \ldots
\end{array}
$$

(di mana $\mathrm{z}=$ Valensi ion; $\sum \mathrm{Mc}=$ Molalitas kation; $\sum \mathrm{ma}=$ Molalitas anion.

- Analisis Indeks Kejenuhan. Analisis Indeks Kejenuhan atau Saturation Indices (SI) dilakukan untuk mengetahui sifat air sampel terhadap tingkat pelarutan batuan karbonat (agresivitas air) terutama terhadap $\mathrm{CaCO}_{3}$, dibantu dengan software Netpath (Plummer, et al., 1991) dengan formulasi sebagai berikut.

$$
\begin{aligned}
& {\left[\mathrm{CO}_{3}{ }^{-}\right]\left[\mathrm{Ca}^{2+}\right]} \\
& \text { SI } \mathrm{CaCO}_{3}=\log 10
\end{aligned}
$$

(dimana $\left[\mathrm{CO}_{3}^{-}\right]$adalah aktivitas ion karbonat; $\left[\mathrm{Ca}^{2+}\right]$ adalah aktivitas ion kalsium; $\mathrm{Ksp} \mathrm{CaCO}_{3}$ adalah solubility product kalsit $=10^{-8,48}$ ) 
- Melakukan analisis bivariate plot (non-discrete parameter), yaitu $\odot \mathrm{i}$ ) hubungan debitkonsentrasi; (ii) hubungan linier antara kalsium dan bikarbonat secara time series pada masing-masing titik sampling: (iii) hubungan DHL-kalsium dan karbonat; (iv) scatter plot natrium dan klorida; (v) hubungan aliran dasar-debit aliran; (vi) hubungan aliran dasar log $\mathrm{PCO}_{2}$; dan (vii) hubungan aliran dasar-kasium dan bikarbonat;

\subsubsection{Metode penelitian tahun ketiga:}

Penelitian pada tahun ke-3 mempunyai 2 tujuan, dengan langkah-langkah:

- Penyerapan karbon inorganik diperoleh melalui pendekatan dengan metode Standard Limestone Tablets. Metode Standard Limestone Tablets digunakan untuk mengetahui laju pelarutan pada bentanglahan karst. Laju pelarutan dapat diketahui dengan mengetahui selisih berat antara limestone tablets saat belum ditanam dengan limestone tablets setelah ditanam di dalam tanah pada kedalaman 20,50, dan $70 \mathrm{~cm}$ pada lapisan tanah atas.

- menghitung luas daerah tangkapan mataair atau sungai bawah tanah dilakukan dengan rumus imbangan air sederhana yaitu:

$$
(\mathrm{P}-\mathrm{E}) \times \mathrm{A}=\mathrm{Q}
$$

di mana, $\mathrm{P}=$ hujan $(\mathrm{mm}) ; \mathrm{E}=$ evpotranspirasi $(\mathrm{mm}) ; \mathrm{A}=$ luas daerah $\operatorname{tangkapan}\left(\mathrm{mm}^{2}\right)$

- $\quad$ menghitung penyerapan karbon di karst dengan rumus Corbel (1956)

$$
\mathrm{V}=\frac{4 \text { ET }}{------}
$$

di mana V : Tingkat pelarutan gamping $\left(\mathrm{m}^{3} / \mathrm{year} / \mathrm{km}^{2}\right)$; E : Run off (Hujan-penguapan) dalam desimeter (dm); $\mathrm{T}$ : konsentrasi $\mathrm{CaCO}_{3}$ di mataair karst (mg/l)

Selanjutnya, diagram alir metode penelitian disajikan pada Gambar 4.1. 


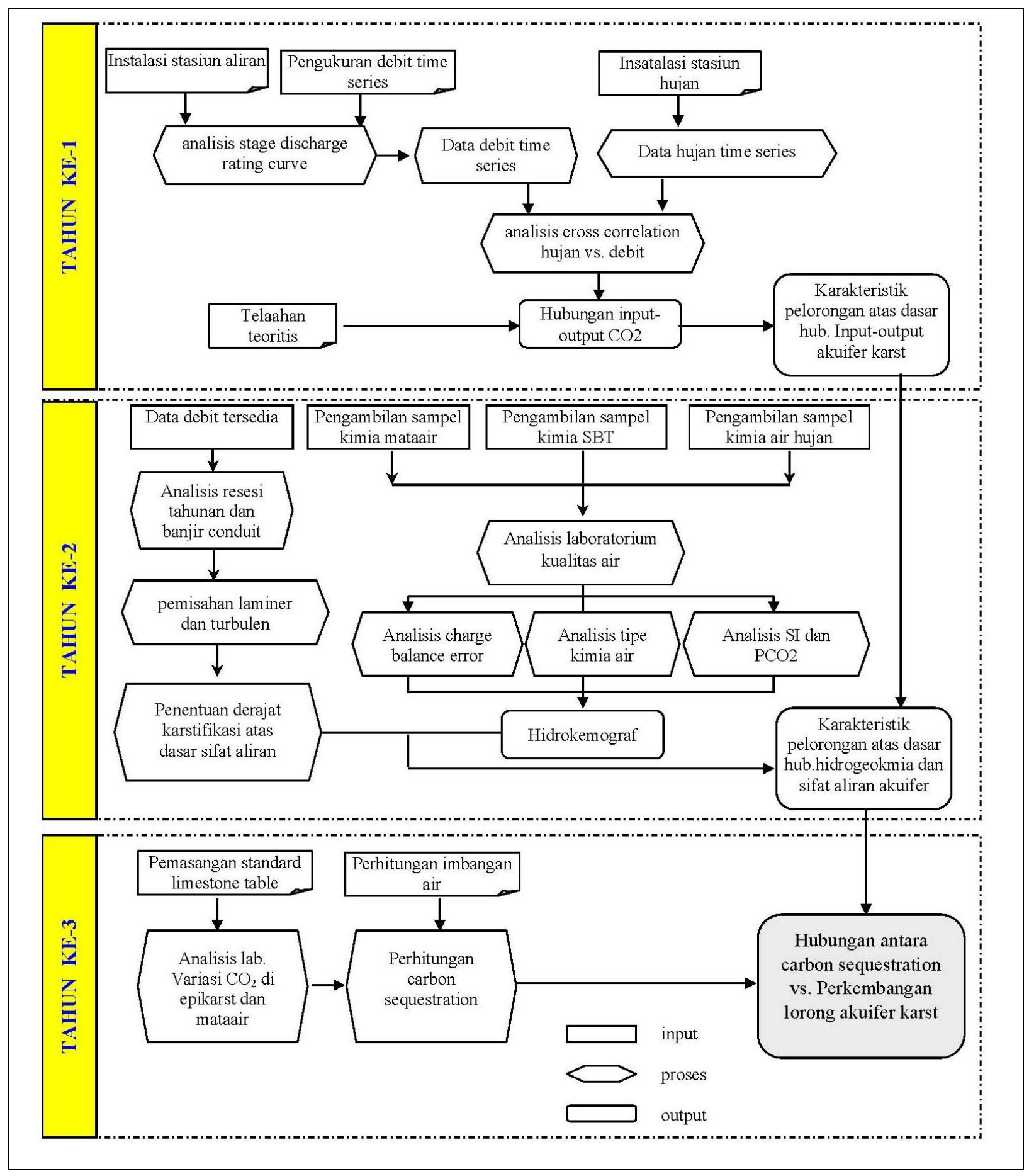

Gambar 4.1. Diagram Alir Metode Penelitian 


\section{BAB 5 \\ HASIL DAN LUARAN YANG DICAPAI}

\subsection{Hasil}

\subsubsection{Variasi temporal aliran di Mataair Kakap (Wonogiri)}

\section{a. Hubungan tinggi muka air dan debit Mataair Kakap}

Mataair Kakap merupakan salah satu mataair kontak karst yang berada di perbatasan Karst Gunung Sewu dengan Ledok Baturetno, Kabupaten Wonogiri. Mataair Kakap berada pada perpotongan Formasi Wonosari dengan Formasi Baturetno. Mataair Kakap selalu berair sepanjang tahun (perenial) dan mempunyai morfometri alur sungai yang memungkinkan untuk dipasang alat pencatat tinggi muka air (water level data logger), sehingga kondisi aliran sepanjang tahun dapat tercatat (Gambar 5.1).
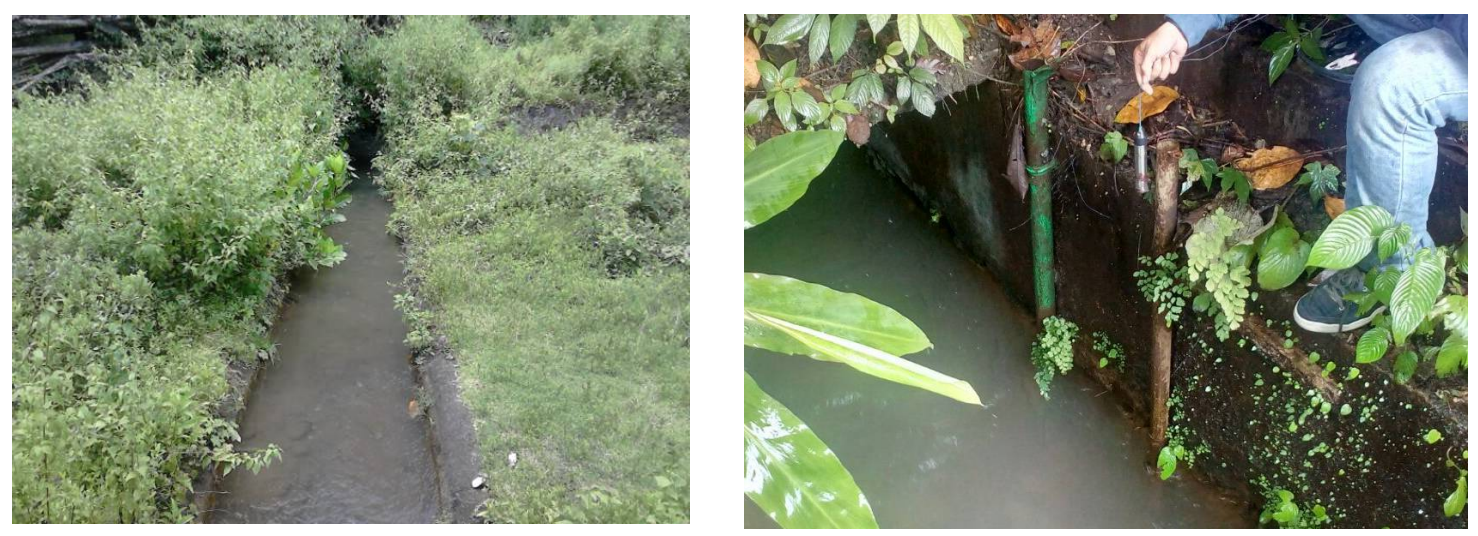

Gambar 5.1. Kondisi Aliran Mataair Kakap (kiri) dan Alat Pengukur Tinggi Muka Air yang terpasang

Untuk memperoleh variasi debit tahunan, diperlukan kurva hubungan tinggi muka air dan debit (stage discharge rating curve), yang dicari dengan melakukan pengukuran debit aliran pada saat debit kecil, rata-rata, dan besar, dari Januari 2016 sampai dengan Pebruari 2017, dan disajikan pada Tabel 5.1. Dari data hasil pengukuran tersebut dibuat kurva regresi (Gambar 5.2). Hubungan antara tinggi muka air dan debit aliran di Mataair Kakap dinyatakan sebagai:

$$
y=14,103 e^{8,7333 x}
$$

di mana: y adalah debit aliran (liter/detik) dan x adalah tinggi muka air (m) 
Tabel 5.1. Hasil Pengukuran Debit Aliran Mataair Kakap

\begin{tabular}{|c|r|r|}
\hline $\begin{array}{c}\text { Tanggal } \\
\text { Pengukuran }\end{array}$ & \multicolumn{1}{c|}{ TMA } & $\begin{array}{c}\text { Debit } \\
\text { (liter/detik) }\end{array}$ \\
\hline 06-Apr-16 & 0,192 & 104,90 \\
\hline 26-Apr-16 & 0,243 & 129,68 \\
\hline 27-Apr-16 & 0,196 & 103,92 \\
\hline 07-Mei-16 & 0,200 & 110,83 \\
\hline 27-Mei-16 & 0,166 & 81,17 \\
\hline 28-Mei-16 & 0,160 & 76,78 \\
\hline 12-Jun-16 & 0,198 & 64,10 \\
\hline 17-Jun-16 & 0,211 & 64,34 \\
\hline 12 Juli 16 & 0,166 & 58,59 \\
\hline 11 Agst 16 & 0,079 & 28,60 \\
\hline 06-Sep-16 & 0,066 & 25,79 \\
\hline 16-Sep-16 & 0,076 & 17,86 \\
\hline 6-Okt-16 & 0,174 & 33,54 \\
\hline 30-Nov-16 & 0,237 & 103,40 \\
\hline 28-Des-16 & 0,295 & 149,35 \\
\hline 11-Jan-17 & 0,135 & 59,90 \\
\hline
\end{tabular}

Sumber : Pengukuran lapangan 2016-2017

Hasil kurva hubungan tinggi muka air di Mataair Kakap dengan debit alirannya tidak mempunyai hubungan linier karena sifat aliran sungai bawah tanah yang cenderung turbulen dan bukan laminer seperti halnya yang dijumpai pada sungai permukaan. Selanjutnya, rumus (9) digunakan untuk menghitung debit aliran sepanjang tahun pada alat pencatat tinggi muka air yang dipasang di Mataair Kakap. Tinggi muka air yang tercatat di Mataair Kakap mempunyai interval pencatatan tiap 30 menit. Hasil penggambaran variasi debit aliran Mataair Kakap selama satu tahun (Jan 2016 sampai dengan Feb 2016) disajikan pada Gambar 5.2. 


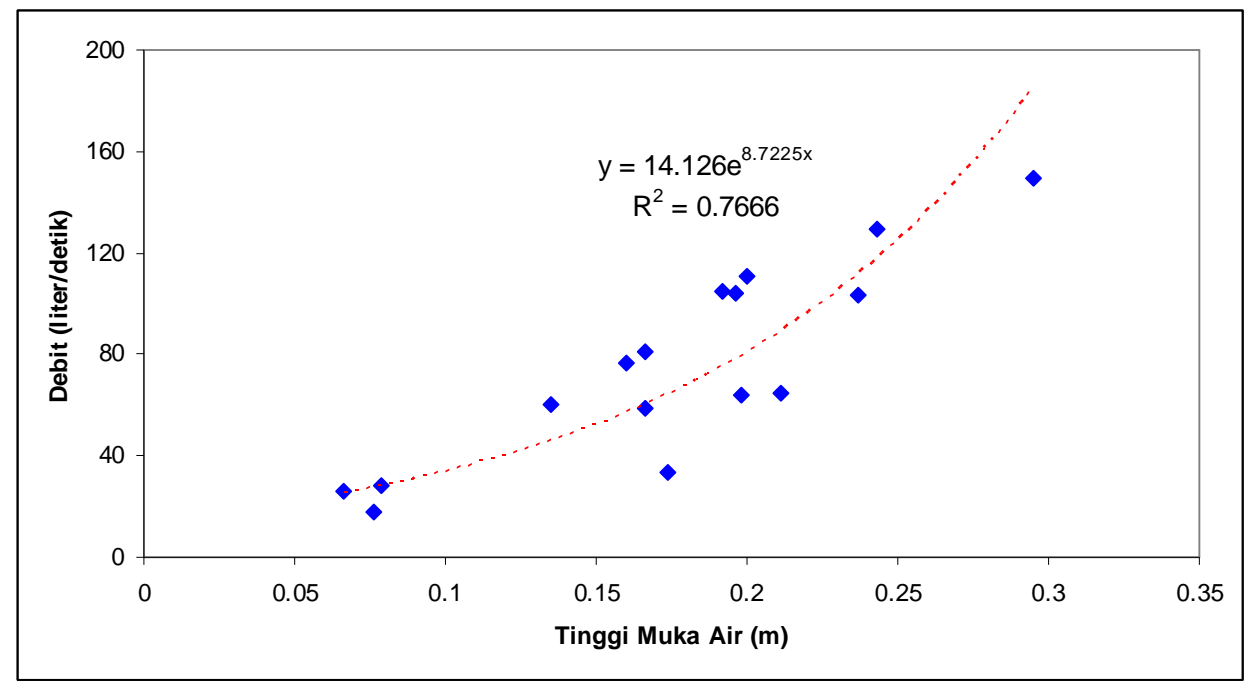

Gambar 5.2. Hubungan Tinggi Muka Air Dan Debit di Mataair Kakap

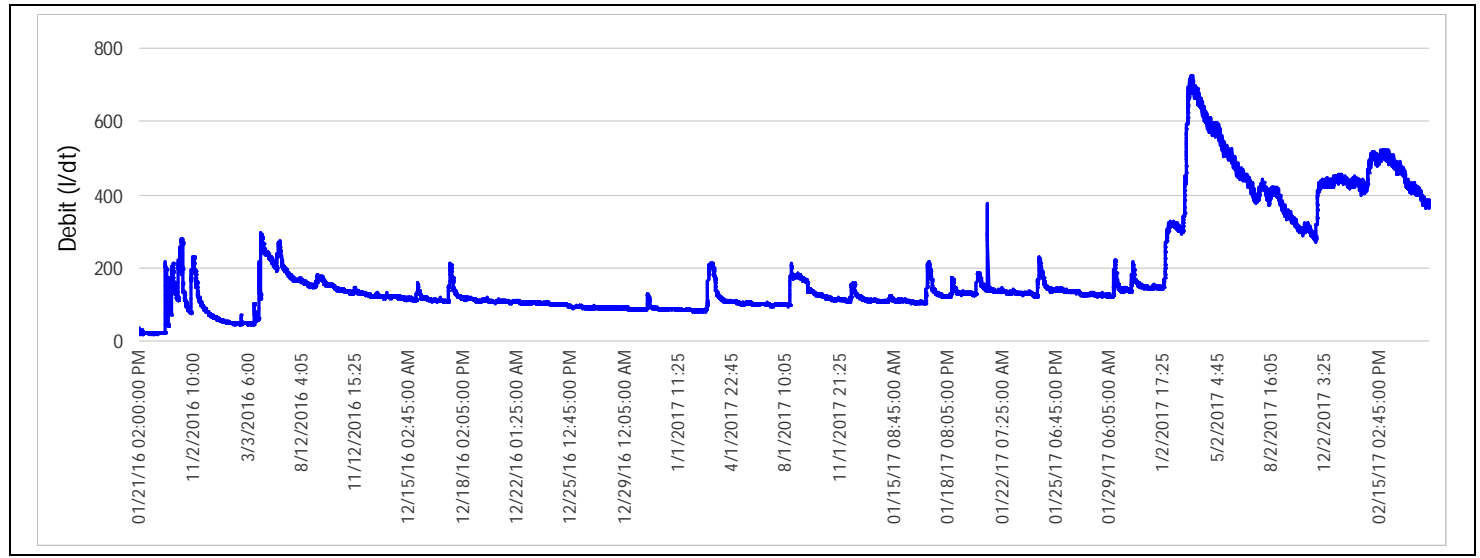

Gambar 5.3. Variasi Debit Aliran di Mataair Kakap Periode Jan 2016 - Peb 2017

Pada penelitian ini, kondisi debit aliran Mataair Kakap diasumsikan mewakili kawasan karst Gunungsewu. Sepanjang tahun, Mataair Kakap selalu dialiri air dan memiliki debit minimum sebesar sekitar 24,44 liter/detik yang terjadi pada puncak musim kemarau. Hasil pencatatan dari Jan 2016 sampai dengan Peb 2012 menunjukkan bahwa debit minimum dijumpai pada tanggal 31 November 2016, sebesar 21,5 liter/detik. Periode tanpa kejadian hujan yang diindikasikan dengan tidak terdapatnya kenaikan debit aliran terjadi dari Bulan Juli hingga Desember. Pada rentang waktu tersebut, secara teori tidak ada kejadian hujan sehingga 
komponen pengisi aliran sungai bawah tanah didominasi oleh aliran diffuse, terutama pada periode bulan Agustus-Desember 2016.

Periode banjir (flood pulse period) dimulai sejak tanggal 22 Januari Desember 2016 sampai akhir masa pencatatan (18 Pebruari 2017). Pada kurun waktu tersebut tercatat 21 kali kejadian banjir yang merupakan efek dari terjadinya hujan pada daerah tangkapan Mataair Kakap. Beberapa banjir yang cukup besar dua diantaranya adalah yang terjadi pada tanggal 3 Pebruari 2017, dengan debit puncak sebesar 717 liter/detik pada pukul 14.00 WIB, dan banjir pada tanggal 15 Pebruari 2015, pukul 15.30 dengan debit puncak mencapai 515,52 liter/detik.

\section{b. Konstanta Resesi Hidrograf Banjir Mataair Kakap}

Konstanta resesi (recession constant atau depletion factor) dapat digunakan untuk mengetahui karakteristik akuifer karst dalam melepaskan komponen-komponen aliran sungai bawah tanah. Model yang dipakai adalah model tangki (tank model) yang dikenalkan oleh Schulz (1976). Aplikasi model resesi ini dapat digunakan untuk menghitung nilai konstanta resesi

saluran/conduit $\left(\mathrm{K}_{\mathrm{c}}\right)$, konstanta resesi aliran antara/fissure $\left(\mathrm{K}_{\mathrm{i}}\right)$, dan konstanta aliran dasar/baseflow $\left(\mathrm{K}_{\mathrm{b}}\right)$.

Di Mataair Kakap, terjadi puluhan kali banjir pada periode satu musim hujan, sedangkan analisis tidak dilakukan pada semua kejadian banjir. Pemilihan banjir yang dianalisis didasarkan pada keterwakilan nilai waktu dari puncak banjir sampai aliran normal ( $\mathrm{T}_{\mathrm{b}}=$ time to baseflow) sehingga banjir-banjir yang kecil atau sangat pendek dapat diabaikan karena secara matematis tidak valid jika dipaksakan diukur konstanta resesinya (Schulz,1976). Konstanta resesi banjir terpilih pada berbagai komponen aliran dicari dengan persamaan:

$$
Q(t)=Q\left(t_{o}\right) e^{-k\left(t-t_{0}\right)}
$$

$\mathrm{k}$ adalah konstanta resesi pada suatu sistem akuifer, $\mathrm{t}$ adalah waktu pada debit ke $\mathrm{t}$, dan $\mathrm{t}_{0}$ adalah waktu pada debit awal resesi. Kemudian jika pada skala semi-log rumus ini dianggap linier, maka:

$$
\begin{gathered}
\ln Q(t)=-k\left(t-t_{o}\right)+\ln Q\left(t_{o}\right) \\
k=-1 / t-t_{o} \ln \left(Q_{t} / Q_{o}\right)
\end{gathered}
$$

Dari 41 kejadian banjir kemudian terpilih 6 kejadian banjir yang debitnya mencukupi dan waktu resesinya cukup panjang sesuai yang disyaratkan oleh Schulz (1976). Selanjutnya, grafik 
tiap kejadian banjir terpilih yang sudah dipisahkan komponen aliran dasarnya (baseflow) pada skala logaritma disajikan pada Gambar 5.4.

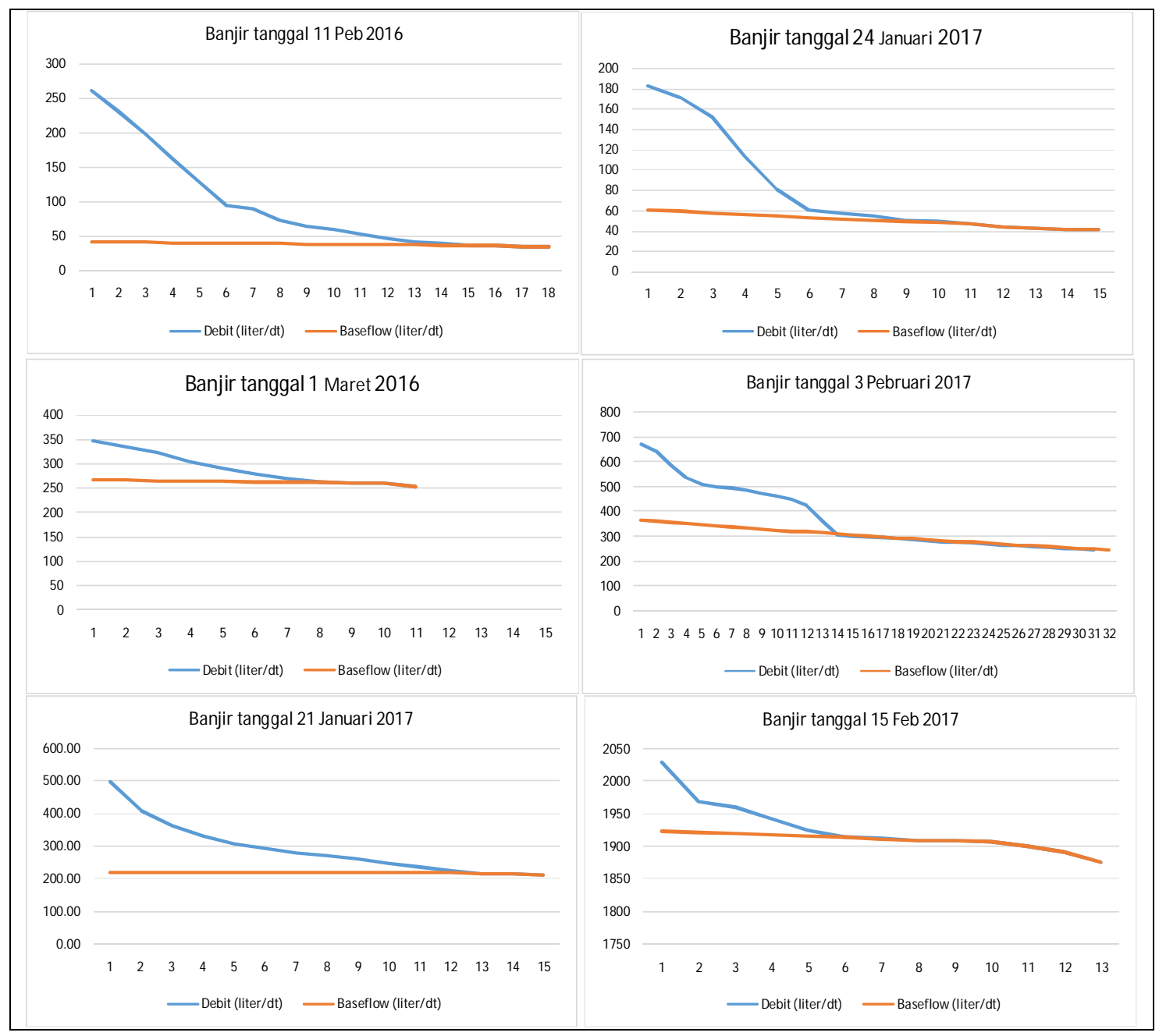

Gambar 5.4. Kejadian Resesi Banjir-Banjir Terpilih Mataair Kakap

Dari Gambar 5.4. tampak bahwa masing-masing kejadian banjir memiliki karakteristik kurva resesi yang berbeda-beda, terlihat dari bentuk kurva resesi yang dikenali dari debit puncak menuju ke aliran dasar. Perbedaan tersebut terlihat dalam paramater waktu resesi dari debit puncak menuju aliran dasar (time to baseflow= $\mathrm{T}_{\mathrm{b}}$ ), dan waktu dari aliran dasar menuju debit puncak (time to peak= $\mathrm{T}_{\mathrm{p}}$ ). Selain itu, kemiringan kurva resesi juga terlihat berbeda-beda pada tiap kejadian banjir yang diakibatkan faktor perbedaan karakteristik hujan pada daerah tangkapan yang tidak selalu seragam secara spasial dari waktu ke waktu (Schulz,1976). Akibatnya, hal ini berpengaruh pada hasil perhitungan nilai konstanta resesi banjir $\mathrm{K}_{\mathrm{c}}, \mathrm{K}_{\mathrm{i}}$, maupun $\mathrm{K}_{\mathrm{b}}$ (Tabel 5.2.).

Secara umum, Nathan and McMahon (1990) menjelaskan bahwa julat nilai konstanta resesi untuk saluran $\left(\mathrm{K}_{\mathrm{c}}\right)$ adalah 0,2-0,8; aliran antara $\left(\mathrm{K}_{\mathrm{i}}\right)$ adalah 0,7-0,94; dan aliran dasar $\left(\mathrm{K}_{\mathrm{b}}\right)$ 
berkisar 0,93-0,995. Dari perhitungan yang sudah disajikan pada Tabel 4.5. diketahui bahwa nilai $\mathrm{K}_{\mathrm{c}}$ periode banjir di Mataair Kakap mempunyai julat antara 0,101-0,84 dengan nilai rerata sebesar 0,483, sedangkan nilai $\mathrm{K}_{\mathrm{i}}$ berjulat 0,625-0,97 dengan rerata 0,79, dan julat konstanta resesi aliran dasar $\left(\mathrm{K}_{\mathrm{b}}\right)$ menunjukkan variasi antara 0,974-0,99 dengan nilai rata-rata sebesar 0,991 .

Tabel 5.2. Konstanta Resesi, $\mathrm{T}_{\mathrm{p}}$ dan $\mathrm{T}_{\mathrm{b}}$ Hidrograf Banjir Terpilih Mataair Kakap

\begin{tabular}{|c|r|r|c|c|r|r|r|}
\hline No & $\begin{array}{c}\text { Debit } \\
\text { Puncak } \\
\text { (liter/detik) }\end{array}$ & $\begin{array}{c}\text { BFI } \\
\text { Index }\end{array}$ & Kb & Ki & Kc & $\begin{array}{c}\text { Tp } \\
\text { (jam) }\end{array}$ & $\begin{array}{c}\text { Tb } \\
\text { (jam) }\end{array}$ \\
\hline Banjir 1 & 497 & 0,432 & 0,999 & 0,774 & 0,100 & 9 & 13,5 \\
\hline Banjir 2 & 2030 & 0,942 & 0,999 & 0,625 & 0,280 & 3 & 6,5 \\
\hline Banjir 3 & 261 & 0,140 & 0,991 & 0,785 & 0,772 & 4 & 15,5 \\
\hline Banjir 4 & 182 & 0,260 & 0,974 & 0,791 & 0,585 & 5,5 & 9,5 \\
\hline Banjir 5 & 348 & 0,747 & 0,997 & 0,845 & 0,845 & 5,5 & 9,5 \\
\hline Banjir 6 & 681 & 0,446 & 0,987 & 0,972 & 0,316 & 8 & 15,5 \\
\hline & \multicolumn{1}{|c|}{ rerata } & $\mathbf{0 , 4 9 4}$ & $\mathbf{0 , 9 9 1}$ & $\mathbf{0 , 7 9 9}$ & $\mathbf{0 , 4 8 3}$ & $\mathbf{5 , 8}$ & $\mathbf{1 1 , 6}$ \\
\hline
\end{tabular}

Sumber : Pengukuran lapangan dan analisis data tahun 2017

Perhitungan nilai time to peak $\left(\mathrm{T}_{\mathrm{p}}\right)$ yaitu lama waktu yang dibutuhkan oleh aliran sungai bawah tanah dari debit normal untuk mencapai puncak banjir di Mataair Kakap berkisar antara 3 sampai dengan 9 jam sejak hujan mulai turun di daerah tangkapan dengan rata-rata waktu adalah sekitar 5,8 jam untuk mencapai banjir puncak, dengan rerata waktu resesi yang diperlukan dari puncak banjir untuk mencapai aliran dasar $\left(\mathrm{T}_{\mathrm{b}}\right)$ adalah sekitar 11,6 jam. Sementara itu nilai $\mathrm{Kb}$ rata-rata adalah sebesar 0,991, sedangkan nilai Ki dan Kc secara berturut-turut adalah 0,799 dan 0,483 .

\section{c. Pemisahan Aliran Dasar Mataair Kakap}

Pemisahan aliran dasar dilakukan untuk mengetahui prosentase komponen aliran yang mensuplai aliran mataair tergantung dari kondisi pelepasan komponen air dari akuifer karst. Dua jenis aliran yang dipisahkan adalah (1) aliran langsung dan aliran antara (conduit-fissure); dan (2) aliran dasar (diffuse flow). Karena panjangnya data debit tiap 30 menit secara time series selama periode satu tahun pemasangan alat di Mataair Kakap, maka digunakan cara pemisahan aliran dasar secara otomatis yaitu model automated base flow separation by digital filtering method yang dikembangkan oleh Eckhardt (2005), seperti yang sudah dijelaskan pada Rumus (3). Data utama yang diperlukan adalah data konstanta resesi aliran dasar Mataair Kakap ( $\left.\mathrm{K}_{\mathrm{b}}\right)$ 
atau oleh Eckhhardt disebut digital filtering yang nilai reratanya adalah sebesar 0,991. Nilai $\mathrm{BFI}_{\max }$ yang digunakan adalah 0,494 yang diperoleh dari baseflow tertinggi dibagi debit puncaknya. Hasil pemisahan aliran dasar Mataair Kakap disajikan pada Gambar 5.5. dan prosentase bulanannya disajikan pada Tabel 5.3.

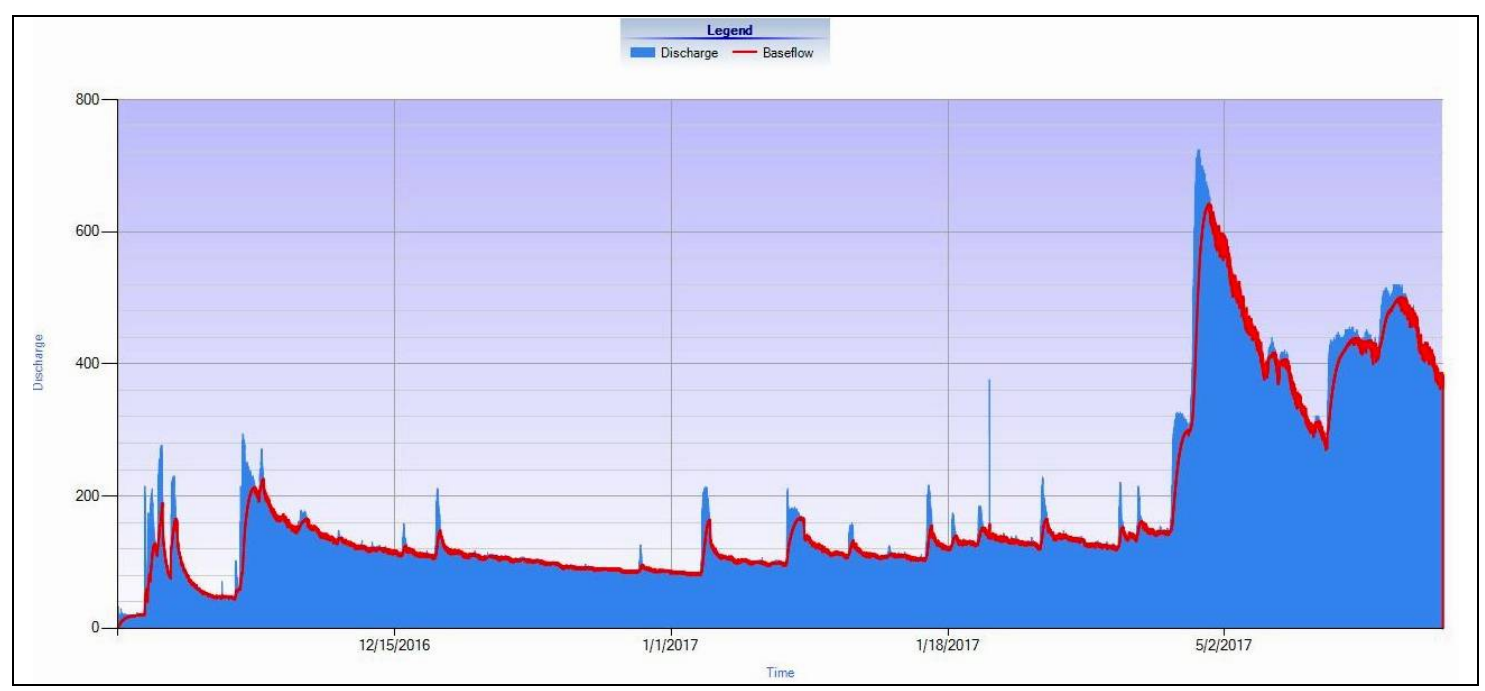

Gambar 5.5. Fluktuasi Aliran Dasar Mataair Kakap periode Jan 2016 - Peb 2017

Dari perhitungan rasio total aliran dasar bulanan terhadap total aliran (Tabel 4.6), tampak bahwa secara umum nilai rasionya mendekati angka sekitar 90\%. Hal ini disebabkan oleh sifat pelepasan aliran akuifer karst yang didominasi oleh retakan bertipe diffuse. Jika dibedakan antara musim penghujan dan kemarau, terlihat perbedaan mengecilnya dominasi diffuse flow yang diakibatkan oleh adanya banjir yang memicu pelepasan komponen aliran conduit menuju mataair. Jika dicermati karakteristik temporalnya, nampak bahwa semakin menuju ke puncak musim kemarau, dominasi aliran dasar semakin besar karena berkurangnya aliran conduit dan fissure yang dilepaskan oleh akuifer karst di sekitar Mataair Kakap. 
Tabel. 5.3. Rasio Aliran Dasar dan Total Aliran Tiap Bulan Mataair Kakap

\begin{tabular}{|c|r|c|c|}
\hline No & \multicolumn{1}{|c|}{ Bulan } & $\begin{array}{c}\text { Prosentase } \\
\text { aliran } \\
\text { dasar (\%) }\end{array}$ & musim \\
\hline 1 & Mar-16 & 79,93 & hujan \\
\hline 1 & Apr-16 & 79,93 & kemarau \\
\hline 2 & Mei-16 & 79,63 & kemarau \\
\hline 3 & Jun-16 & 78,86 & kemarau \\
\hline 4 & Jul-16 & 80,81 & kemarau \\
\hline 5 & Agu-16 & 80,74 & kemarau \\
\hline 6 & Sep-16 & 76,60 & kemarau \\
\hline 7 & Okt-16 & 76,09 & kemarau \\
\hline 8 & Nov-16 & 72,30 & hujan \\
\hline 9 & Des-16 & 69,54 & hujan \\
\hline 10 & Jan-17 & 84,23 & hujan \\
\hline 11 & Feb-175 & 80,78 & hujan \\
\hline
\end{tabular}

Sumber : hasil analisis data 2017

Rasio aliran dasar dan total aliran pada musim penghujan pada bulan-bulan tertentu menunjukkan angka yang lebih kecil dibandingkan pada musim kemarau, dan mempunyai kecenderungan membesar seiring dengan berakhirnya musim hujan (Maret-April 2016). Sebagai contoh rasio pada bulan Desember 2017 menunjukkan angka 69,54 \% yang berarti total alirannya terpengaruh kontribusi dari aliran conduit. Rasio yang disajikan pada Tabel 5.3 merupakan nilai rata-rata bulanan, sehingga tidak menunjukkan rasio per kejadian hujan.

Rasio komponen aliran diffuse pada saat banjir terhadap total aliran Mataair Kakap sangat berbeda dengan rasio bulanannya (Tabel 5.4). Pada awal sampai tengah musim hujan, rasio selalu kurang dari 50\% yaitu berkisar antara 14-46\%, bahkan pada kejadian 3 Pebruari 2017, rasio menunjukkan angka yang kecil yaitu 14,68\%. Hal ini mengindikasikan bahwa akuifer karst belum menambah pasokan komponen diffuse flow menuju sungai, sementara pasokan conduit flow dari permukaan karst menjadi dominan saat kejadian banjir. Kemudian, jika periode musim hujan sudah berakhir, maka dari waktu ke waktu kecenderungan rasio diffuse flow mengalami peningkatan. 
Tabel. 5.4. Rasio Aliran Dasar dan Total Aliran pada Kejadian Banjir Terpilih di Mataair Kakap

\begin{tabular}{|c|c|c|c|c|c|}
\hline \multirow{2}{*}{ No } & \multicolumn{2}{|c|}{ Waktu banjir } & \multirow{2}{*}{$\begin{array}{c}\text { Debit } \\
\text { puncak } \\
\text { (liter/detik) }\end{array}$} & \multirow{2}{*}{$\begin{array}{c}\text { Prosentase } \\
\text { aliran } \\
\text { dasar }(\%)\end{array}$} & \multirow{2}{*}{$\begin{array}{l}\text { Periode } \\
\text { hujan }\end{array}$} \\
\hline & Tanggal & Jam & & & \\
\hline 1 & $11 / 02 /$ & 0 & 265,6 & 43 & Tengah \\
\hline 2 & $01 / 03 / 16$ & 16:00 & 220,6 & 44 & Akhir \\
\hline 3 & $21 / 01 / 17$ & $06: 30$ & 376,2 & 46 & Awal \\
\hline 4 & $24 / 01 / 17$ & $15: 30$ & 215,1 & 26 & Tengah \\
\hline 5 & $03 / 02 / 17$ & $16: 30$ & 717,9 & 14 & Tengah \\
\hline 6 & $15 / 02 / 17$ & 15:00 & 506,3 & 44 & Tengah \\
\hline
\end{tabular}

\subsubsection{Variasi temporal aliran di Mataair Sumbersemen (Rembang)}

\section{a. Hubungan tinggi muka air dan debit Mataair Sumbersemen}

Mataair Sumbersemen terletak di Desa Gading, Kecamatan Sale, Kabupaten Rembang. Mataair Sumbersemen merupakan salah satu mataair yang terbesar debitnya di Kecamatan Sale dan mengalir sepanjang tahun (perennial). Hal ini menunjukkan bahwa kondisi akuifer memiliki simpanan air yang cukup, sehingga mataair ini dijadikan sumber air oleh PDAM Kabupaten Tuban. Kondisi Mataair secara lebih jelas dapat dilihat pada Gambar 5.6.

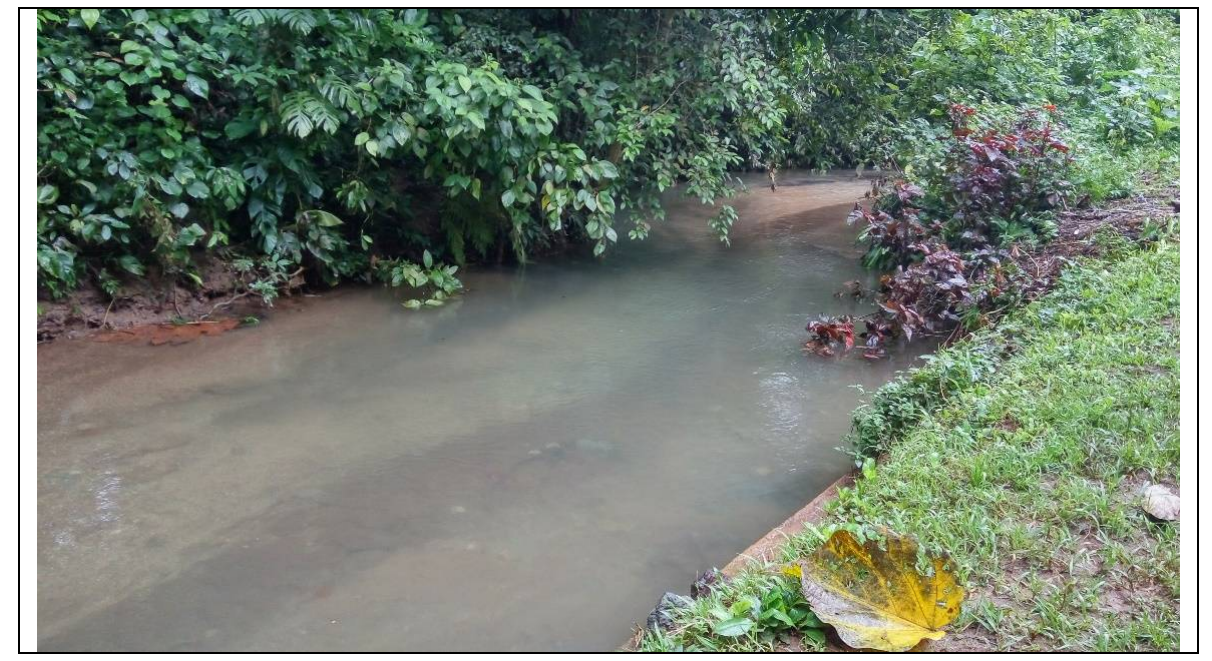

Gambar 5.6. Mataair Sumbersemen

Mataair Sumbersemen memiliki aliran yang tenang atau biasa disebut dengan aliran laminer dalam keadaan normal. Namun, pada keadaan banjir, aliran berubah menjadi turbulen. Mataair Sumbersemen memiliki morfometri tepian aliran yang memungkinkan untuk dilakukan 
pemasangan alat pencatat tinggi muka air (water level logger) seperti yang disajikan pada Gambar 5.7.

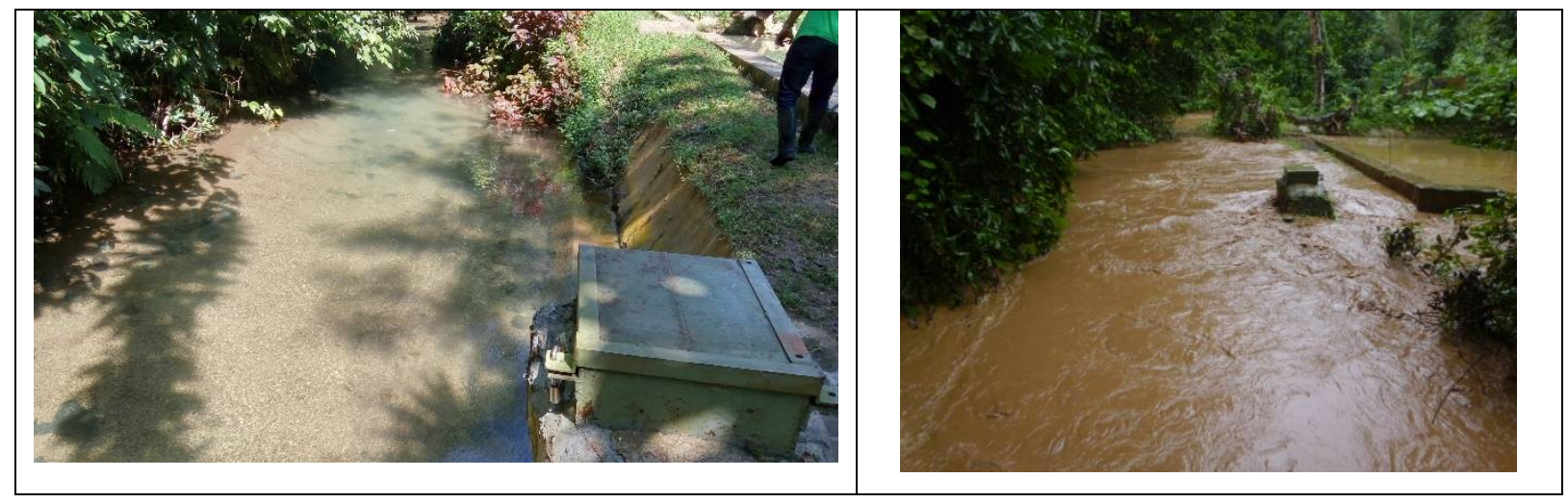

Gambar 5.7. TMA mataair pada kondisi normal (kiri) danTMA mataair pada kondisi banjir

Pencatatan tinggi muka air (TMA) Mataair Sumbersemen dilakukan selama periode bulan Januari 2016 hingga Agustus 2017. Selain pemasangan alat pencatat TMA otomatis juga dilakukan pengukuran debit mataair pada berbagai variasi aliran. Nilai debit yang diperoleh akan dipasangkan dengan data TMA untuk menentukan hubungan dalam bentuk stage discharge rating curve. Pengukuran debit (Gambar 5.9) dilakukan pada periode penelitian selama ada perbedaan TMA pada mataair (TMA rendah, sedang, dan tinggi). Hasil pengukuran debit dapat dilihat pada Tabel 5.4.

Tabel 5.4. Hasil Pengukuran Debit Aliran Mataair Sumbersemen

\begin{tabular}{|c|r|r|}
\hline Tanggal & \multicolumn{1}{|c|}{$\begin{array}{c}\text { TMA } \\
(\mathrm{m})\end{array}$} & \multicolumn{1}{c|}{$\begin{array}{c}\text { Debit } \\
(\text { ltr/dtk })\end{array}$} \\
\hline $30 / 01 / 2016$ & 0,4 & 510 \\
\hline $05 / 02 / 2016$ & 0,6 & 640 \\
\hline $26 / 02 / 2016$ & 0,8 & 790 \\
\hline $27 / 05 / 2016$ & 1,0 & 940 \\
\hline $18 / 06 / 2016$ & 1,2 & 1100 \\
\hline $26 / 02 / 2016$ & 1,6 & 1420 \\
\hline $18 / 06 / 2016$ & 1,8 & 1580 \\
\hline $18 / 06 / 2016$ & 2,0 & 1740 \\
\hline $21 / 01 / 2017$ & 0,5 & 550 \\
\hline $13 / 02 / 2017$ & 0,5 & 520 \\
\hline
\end{tabular}

Sumber: pengukuran lapangan 2016-2017 
Persamaan yang ada kemudian digunakan untuk menghitung debit aliran berdasarkan logger yang memiliki interval pencatatan setiap 30 menit. Setelah memasukkan nilai TMA yang diukur secara manual, maka TMA akan muncul secara otomatis sesuai dengan nilai persamaan. Nilai TMA merupakan vairabel $\mathrm{x}$ yang dimasukkan kedalam rumus rating curve. Kurva hubungan TMA dan debit Mataair Sumbersemen dapat dilihat pada Gambar 5.8. Hasil persamaan regresi menunjukkan nilai determinasi yang tinggi, yaitu 0,998. Nilai tersebut menunjukkan bahwa kedua variabel memiliki hubungan yang positif, yang berarti bahwa nilai debit dipengaruhi faktor TMA sebesar 99,8\%. Selanjutnya, hidrograf aliran selama periode pengukuran ditunjukkan pada Gambar 5.10.

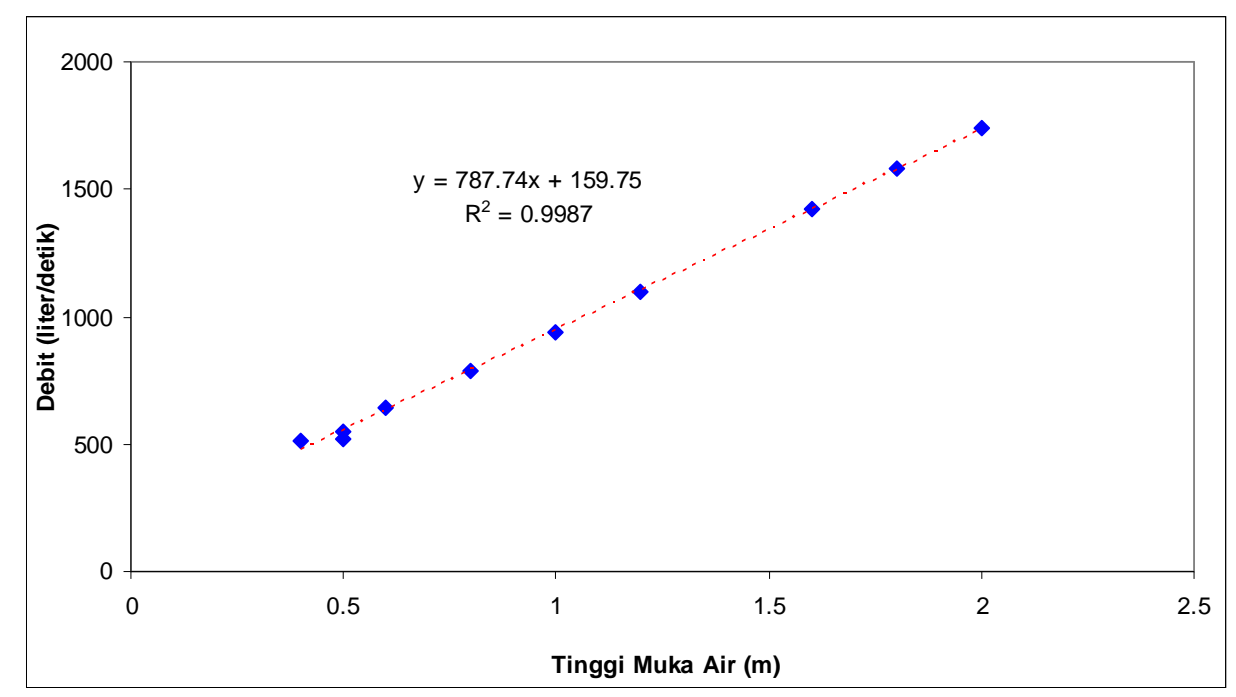

Gambar 5.8. Stage Discharge Rating Curve Mataair Sumbersemen (Sumber: Olah Data, 2017)

Persamaan kurva regresi yang dihasilkan dari pengukuran tersebut adalah:

$$
Y=787,74 x+159.75
$$

di mana: y adalah debit aliran (liter/detik) dan x adalah TMA (m) 


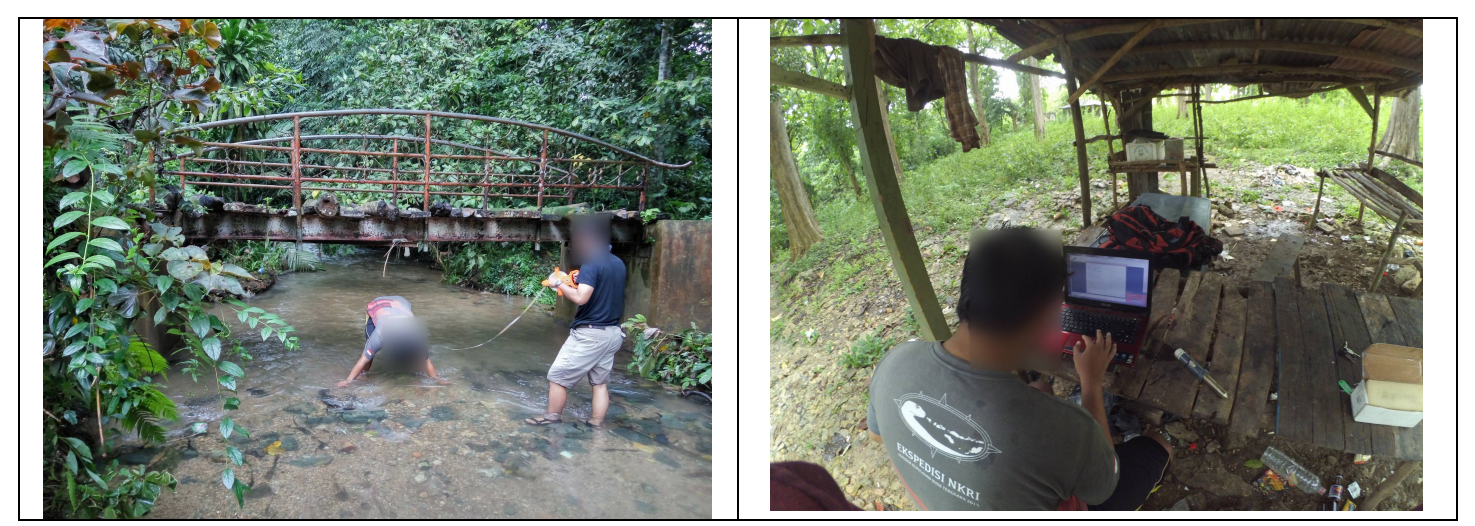

Gambar 5.9. Pengukuran debit dengan slope area method (kiri) download data logger TMA (Sumber: Foto lapangan 2017)

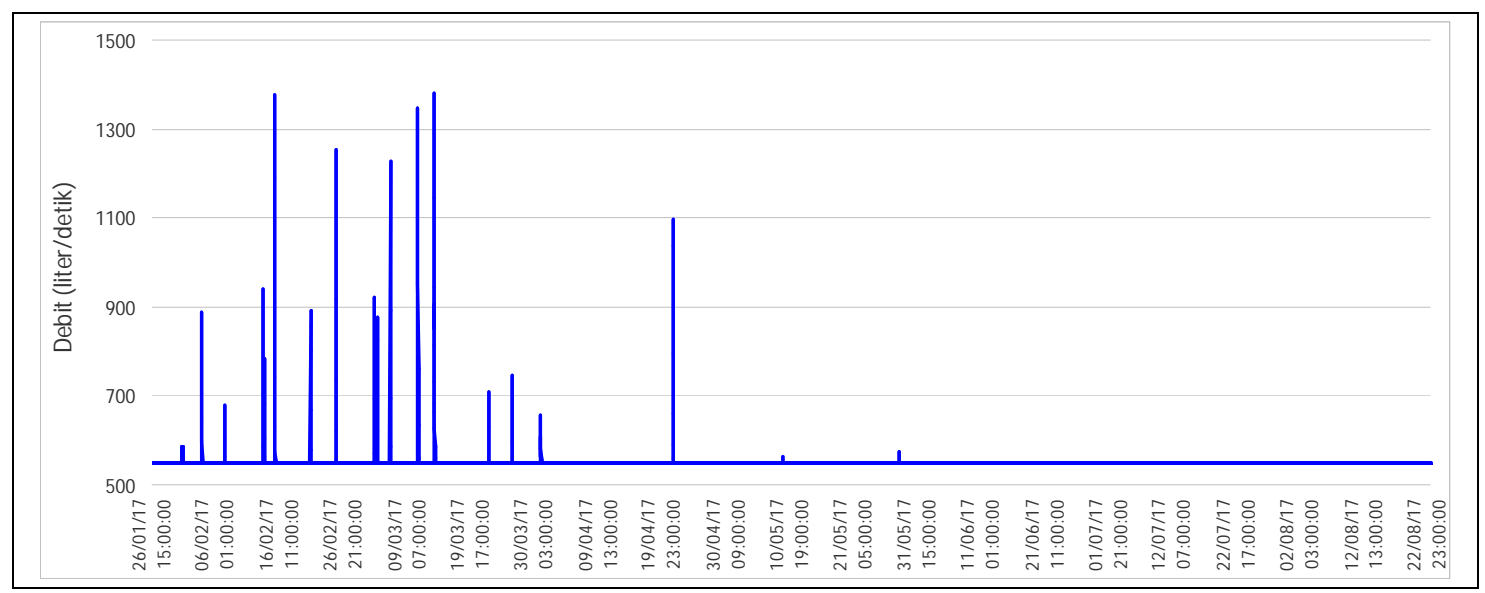

Gambar 5.10. Hidrograf aliran Mataair Sumbersemen selama periode pengukuran

\section{b.Konstanta Resesi Hidrograf Banjir Sumbersemen}

Selama periode penelitian terdapat 7 banjir yang digunakan untuk perhitungan resesi hidrograf. Pemilihan kejadian banjir yang digunakan untuk perhitungan resesi hidrograf adalah banjir yang cukup besar dengan waktu puncak banjir kembali ke aliran dasar (time to base $=\mathrm{T}_{\mathrm{b}}$ ) cukup lama. Sampel kejadian resesi banjir yang dipilih dapat dilihat pada Gambar 5.11.

Selanjutnya, hasil perhitungan nilai resesi disajikan pada Tabel 5.5. Pada Mataair Sumbersemen ini nilai $\mathrm{K}_{\mathrm{b}}$ rata-rata adalah sebesar 0,988 dan tidak dijumpai nilai $\mathrm{K}_{\mathrm{i}}$ dan $\mathrm{K}_{\mathrm{c}}$ yang menunjukkan aliran langsung/aliran cepat/conduit yang mengimbuh mataair ini hanya sesaat dan tidak melalui akuifer tetapi lebih dominan melalui permukaan, yang diperkuat dengan perhitungan rerata nilai $T_{p}$ dan $T_{b}$ yang relatif singkat, yaitu 3,8 dan 4,8 jam saja. Hal ini 
mengindikasikan bahwa Mataair Sumbersemen ini sangat didominasi oleh simpanan aliran airtanah dalam yang bersifat seragam dan stabil sepanjang tahun.

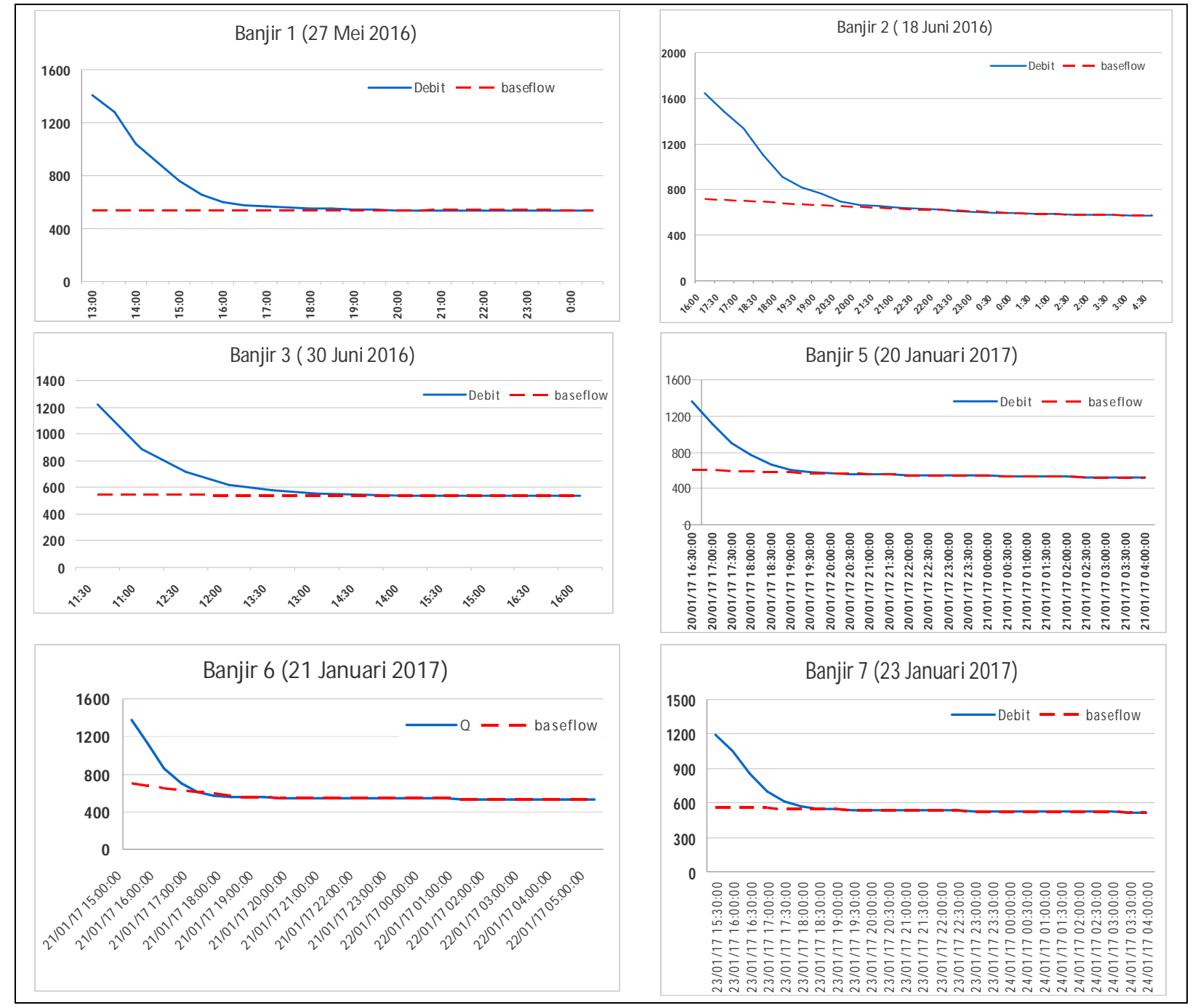

Gambar 5.11. Kurva Resesi sampel banjir Mataair Sumbersemen

Tabel 5.5. Konstanta Resesi, $\mathrm{T}_{\mathrm{p}}$ dan $\mathrm{T}_{\mathrm{b}}$ Hidrograf Banjir Terpilih Mataair Sumbersemen

\begin{tabular}{|c|c|c|c|c|c|c|c|c|}
\hline \multirow{2}{*}{ No } & \multicolumn{2}{|c|}{ Waktu } & \multirow{2}{*}{$\begin{array}{c}\text { Debit } \\
\text { puncak(lt/dt) }\end{array}$} & \multirow{2}{*}{$\begin{array}{c}\mathbf{K r} \\
\text { Baseflow } \\
\left(\mathbf{K}_{\mathbf{b}}\right)\end{array}$} & \multirow{2}{*}{$\begin{array}{c}\mathbf{K r} \\
\text { Interflow } \\
\left(\mathbf{K}_{\mathbf{i}}\right)\end{array}$} & \multirow{2}{*}{$\begin{array}{c}\mathbf{K r} \\
\text { channel } \\
\left(\mathbf{K}_{\mathbf{c}}\right)\end{array}$} & \multirow{2}{*}{$\begin{array}{c}\mathbf{T}_{\mathbf{p}} \\
(\mathbf{j a m})\end{array}$} & \multirow{2}{*}{$\underset{(j a m)}{\mathbf{T}_{\mathbf{b}}}$} \\
\hline & tanggal & jam & & & & & & \\
\hline 1 & $27 / 05 / 16$ & $13: 00$ & 1410 & 0,991 & - & - & 4 & 6,5 \\
\hline 2 & $18 / 06 / 16$ & $16: 00$ & 1648 & 0,988 & - & - & 3,5 & 7,5 \\
\hline 3 & $30 / 06 / 16$ & $06: 30$ & 1224 & 0,998 & - & - & 4 & 5 \\
\hline 4 & $09 / 10 / 16$ & $15: 30$ & 1229 & 0,993 & - & - & 3,5 & 2,5 \\
\hline 5 & $20 / 1 / 17$ & $16: 30$ & 1367 & 0,991 & - & - & 4,5 & 5 \\
\hline 6 & $21 / 1 / 17$ & 15:00 & 697 & 0,966 & - & - & 3 & 3 \\
\hline 7 & $23 / 1 / 17$ & $15: 30$ & 1195 & 0,995 & - & - & 4 & 4 \\
\hline & & & rerata & 0.988 & - & - & 3,8 & 5,5 \\
\hline
\end{tabular}




\section{c. Pemisahan Aliran Dasar Sumbersemen}

Pemisahan aliran dasar dilakukan untuk mengetahui prosentase komponen aliran yang mensuplai aliran SBT tergantung dari kondisi pelepasan komponen air dari akuifer karst. Dua jenis aliran yang dipisahkan adalah (1) aliran langsung dan aliran antara (conduit-fissure); dan (2) aliran dasar (diffuse flow). Karena panjangnya data debit tiap 30 menit secara time series selama periode satu tahun pemasangan alat di Sumbersemen, maka digunakan cara pemisahan aliran dasar secara otomatis yaitu model automated base flow separation by digital filtering method yang dikembangkan oleh Eckhardt (2005), seperti yang sudah dijelaskan pada Rumus (3). Data utama yang diperlukan adalah data konstanta resesi aliran dasar Sumbersemen $\left(\mathrm{K}_{\mathrm{b}}\right)$ atau oleh Eckhhardt disebut digital filtering yang nilai reratanya adalah sebesar 0,988. Nilai $\mathrm{BFI}_{\max }$ yang digunakan adalah 0,494 yang diperoleh dari baseflow tertinggi dibagi debit puncaknya. Hasil pemisahan aliran dasar Mataair Sumbersemen disajikan pada Gambar 5.12. dan prosentase bulanannya disajikan pada Tabel.5.6.

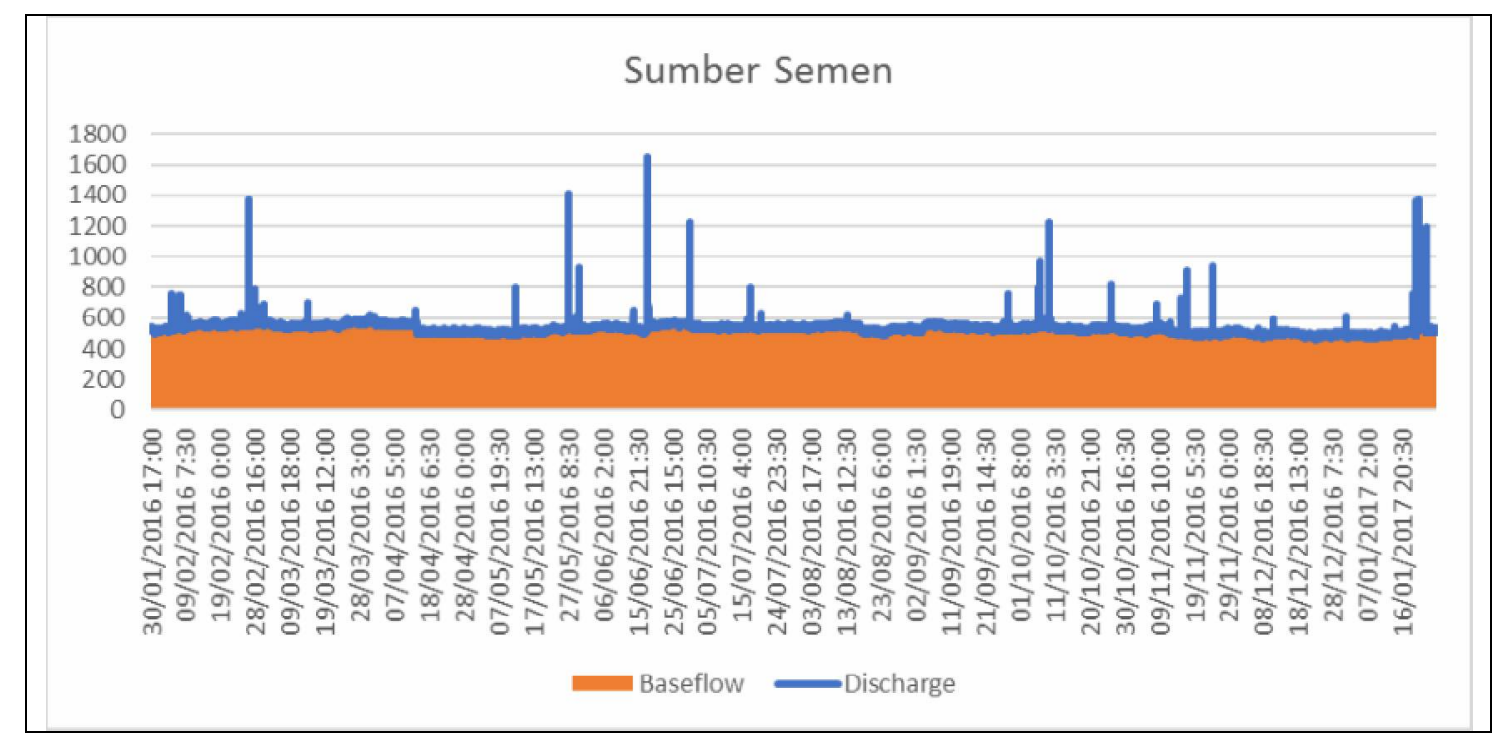

Gambar 5.12. Fluktuasi Aliran Dasar Mataair Kakap periode Januari 2016 - Agustus 2017

Dari perhitungan rasio total aliran dasar bulanan terhadap total aliran (Tabel 5.6), tampak bahwa secara umum nilai rasionya adalah 99\%. Hal ini disebabkan oleh sifat pelepasan aliran akuifer karst yang didominasi oleh retakan bertipe diffuse. 
Tabel 5.6. Rasio Aliran Dasar dan Total Aliran Tiap Bulan Mataair Sumbersemen

\begin{tabular}{|l|l|r|c|}
\hline No & Bulan & \multicolumn{1}{|l|}{$\begin{array}{l}\text { Rasio } \\
(\boldsymbol{\%})\end{array}$} & musim \\
\hline 1 & Februari 2016 & 99 & hujan \\
\hline 2 & Maret 2016 & 99 & hujan \\
\hline 3 & Apri 2016 & 99 & hujan \\
\hline 4 & Mei 2016 & 99 & kemarau \\
\hline 5 & Juni 2016 & 99 & kemarau \\
\hline 6 & Juli 2016 & 99 & kemarau \\
\hline 7 & Agustus 2016 & 99 & kemarau \\
\hline 8 & September 2016 & 99 & kemarau \\
\hline 9 & Oktober 2016 & 99 & kemarau \\
\hline 10 & November 2016 & 99 & kemarau \\
\hline 11 & Desember 2016 & 99 & hujan \\
\hline 12 & Januari 2016 & 99 & hujan \\
\hline
\end{tabular}

Rasio komponen aliran diffuse pada saat banjir terhadap total aliran Mataair Sumbersemen sangat berbeda dengan rasio bulanannya (Tabel 5.7). Sepanjang musim hujan, rasio selalu kurang dari 50\% yaitu berkisar antara 38-48\%, bahkan pada kejadian 20 Januari 2017, rasio menunjukkan angka yang kecil yaitu 38\%. Hal ini mengindikasikan bahwa akuifer karst belum menambah pasokan komponen diffuse flow menuju mataair, sementara pasokan conduit flow atau aliran permukaan dari permukaan karst menjadi dominan saat kejadian banjir. Kemudian, jika periode musim hujan sudah berakhir, maka dari waktu ke waktu kecenderungan rasio diffuse flow mengalami peningkatan.

Tabel. 5.7. Rasio Aliran Dasar dan Total Aliran pada Kejadian Banjir Terpilih Sumbersemen

\begin{tabular}{|c|c|c|c|c|c|}
\hline \multirow{2}{*}{ No } & \multicolumn{2}{|c|}{ Waktu banjir } & \multirow{2}{*}{$\begin{array}{c}\text { Debit puncak } \\
\text { (liter/detik) }\end{array}$} & \multirow{2}{*}{$\begin{array}{c}\text { Rasio } \\
(\%)\end{array}$} & \multirow{2}{*}{$\begin{array}{c}\text { Periode } \\
\text { hujan }\end{array}$} \\
\hline & Tanggal & Jam & & & \\
\hline 1 & $27 / 05 / 16$ & 13:00 & 1410 & 42 & Akhir \\
\hline 2 & $18 / 06 / 16$ & $16: 00$ & 1648 & 39 & Akhir \\
\hline 3 & $30 / 06 / 16$ & 06:30 & 1224 & 48 & Akhir \\
\hline 4 & $09 / 10 / 16$ & $15: 30$ & 1229 & 44 & Awal \\
\hline 5 & $20 / 1 / 17$ & $16: 30$ & 1367 & 38 & Tengah \\
\hline 6 & $21 / 1 / 17$ & 15:00 & 697 & 38 & Tengah \\
\hline 7 & $23 / 1 / 17$ & $15: 30$ & 1195 & 47 & Tengah \\
\hline
\end{tabular}


5.1.3. Perbandingan nilai konstanta resesi, aliran dasar, dan karakteristik penyimpanan antara Mataair Kakap (Karst Gunungsewu-Wonogiri) dan Mataair Sumbersemen (Karst Rembang)

Perbandingan nilai nilai konstanta resesi, aliran dasar, dan karakteristik penyimpanan antara Mataair Kakap (Karst Gunungsewu-Wonogiri) dan Mataair Sumbersemen (Karst Rembang) disajikan pada Tabel 5.8.

Tabel 5.8. Kondisi Komponen Aliran Akuifer Karst Atas Dasar Perbandingan Angka Paramater Hidrograf dan aliran dasar

\begin{tabular}{|c|c|c|c|}
\hline $\begin{array}{l}\text { Paramater } \\
\text { hidrograf }\end{array}$ & Mataair & Perbandingan & Karakteristik \\
\hline$K_{b}=\mathbf{0 , 9 9 1}$ & \multirow{7}{*}{$\begin{array}{c}\text { Kakap } \\
\text { (Karst } \\
\text { Gunungse } \\
\text { wu) }\end{array}$} & > Sumbersemen & $\begin{array}{l}\text { Akuifer melepaskan komponen diffuse lebih lambat } \\
\text { dari pada akuifer di Mataair Sumbersemen }\end{array}$ \\
\hline $\mathrm{K}_{\mathrm{i}}=\mathbf{0 , 7 9 9}$ & & terdeteksi & Terdapat simpanan air pada rekahan fissure \\
\hline $\mathrm{K}_{\mathrm{c}}=\mathbf{0 , 4 8 3}$ & & terdeteksi & Terdapat simpanan air pada rekahan conduit \\
\hline $\mathrm{T}_{\mathrm{p}}=\mathbf{5 , 8} \mathbf{j a m}$ & & $>$ Sumbersemen & $\begin{array}{l}\text { Mataair karst merespon aliran conduit dari daerah } \\
\text { tangkapan dengan cepat, meskipun masih lebih lambat } \\
\text { dibanding akuifer di Mataaair Sumbersemen }\end{array}$ \\
\hline $\mathrm{T}_{\mathrm{b}}=\mathbf{1 1 , 6} \mathbf{j a m}$ & & $>$ Sumbersemen & $\begin{array}{l}\text { Mataair karst mempunyai aliran fissure dan conduit } \\
\text { yang cukup lama bertahan saat periode banjir }\end{array}$ \\
\hline $\begin{array}{l}\text { Aliran dasar } \\
\text { bulanan }= \\
\mathbf{7 8 , 3 \%}\end{array}$ & & $<$ Sumbersemen & $\begin{array}{l}\text { Menunjukkan dominasi rekahan bertipe diffuse yang } \\
\text { cukup dominan }\end{array}$ \\
\hline $\begin{array}{l}\text { Aliran dasar } \\
\text { saat banjir = } \\
\mathbf{3 6 , 2 \%}\end{array}$ & & $<$ Sumbersemen & Menunjukkan adanya perkembangan aliran conduit \\
\hline $\mathrm{K}_{\mathrm{b}}=\mathbf{0 , 9 8 8}$ & \multirow{7}{*}{$\begin{array}{c}\text { Sumberse } \\
\text { men } \\
\text { (Karst } \\
\text { Rembang) }\end{array}$} & $<$ Kakap & $\begin{array}{l}\text { Akuifer melepaskan komponen diffuse lebih cepat dari } \\
\text { pada akuifer di Mataair kakap }\end{array}$ \\
\hline $\begin{array}{l}\mathrm{K}_{\mathrm{i}}=\text { tidak } \\
\text { terdeteksi }\end{array}$ & & Tidak terdeteksi & Tidak terdapat simpanan air pada rekahan fissure \\
\hline $\begin{array}{l}\mathrm{K}_{\mathrm{c}}=\text { tidak } \\
\text { terdeteksi }\end{array}$ & & Tidak terdeteksi & Tidak terdapat simpanan air pada rekahan conduit \\
\hline $\mathrm{T}_{\mathrm{p}}=\mathbf{3 , \mathbf { 8 }} \mathbf{j a m}$ & & $<$ Kakap & $\begin{array}{l}\text { Respon yang sangat cepat, kemungkinan berasal dari } \\
\text { aliran permukaan (bukan dari simpanan conduit) }\end{array}$ \\
\hline $\mathrm{T}_{\mathrm{b}}=\mathbf{5 , 5} \mathbf{j a m}$ & & $<$ kakap & $\begin{array}{l}\text { Tidak menunjukkan adanya simpanan fissure atu } \\
\text { conduit }\end{array}$ \\
\hline $\begin{array}{l}\text { Aliran dasar } \\
\text { bulanan = } \\
\mathbf{9 9 \%}\end{array}$ & & > Kakap & $\begin{array}{l}\text { Simpanan aliran dasar yang sangat tinggi, } \\
\text { kemungkinan berasal dari airtanah dalam dan bukan } \\
\text { semata-mata dari lorong diffuse }\end{array}$ \\
\hline $\begin{array}{l}\text { Aliran dasar } \\
\text { saat banjir = } \\
\mathbf{4 2 , 3 \%}\end{array}$ & & > Kakap & $\begin{array}{l}\text { Kecilnya aliran dasar saat banjir lebih disebabkan } \\
\text { aliran permukaan dan bukan dari simpanan fissure atau } \\
\text { conduit }\end{array}$ \\
\hline
\end{tabular}

$* \mathrm{~K}_{\mathrm{c}}=$ konstanta resesi conduit; $\mathrm{K}_{\mathrm{i}}=$ konstanta resesi fissure; $\mathrm{K}_{\mathrm{b}}=$ konstanta resesi diffuse

$* \mathrm{~T}_{\mathrm{p}}=$ time to peak; $\mathrm{T}_{\mathrm{b}}=$ time to baseflow 


\subsubsection{Analisis time-series hujan vs aliran di Mataair Kakap}

Analisis time-series pada penelitian ini menggunakan pasangan data debit aliran dan curah hujan yang dicatat pada setiap interval 30 menit. Perekaman kedua data tersebut dilakukan selama periode satu tahun. Gambar 5.13 menunjukkan pasangan data debit dan hujan di Mataair Kakap selama satu tahun.

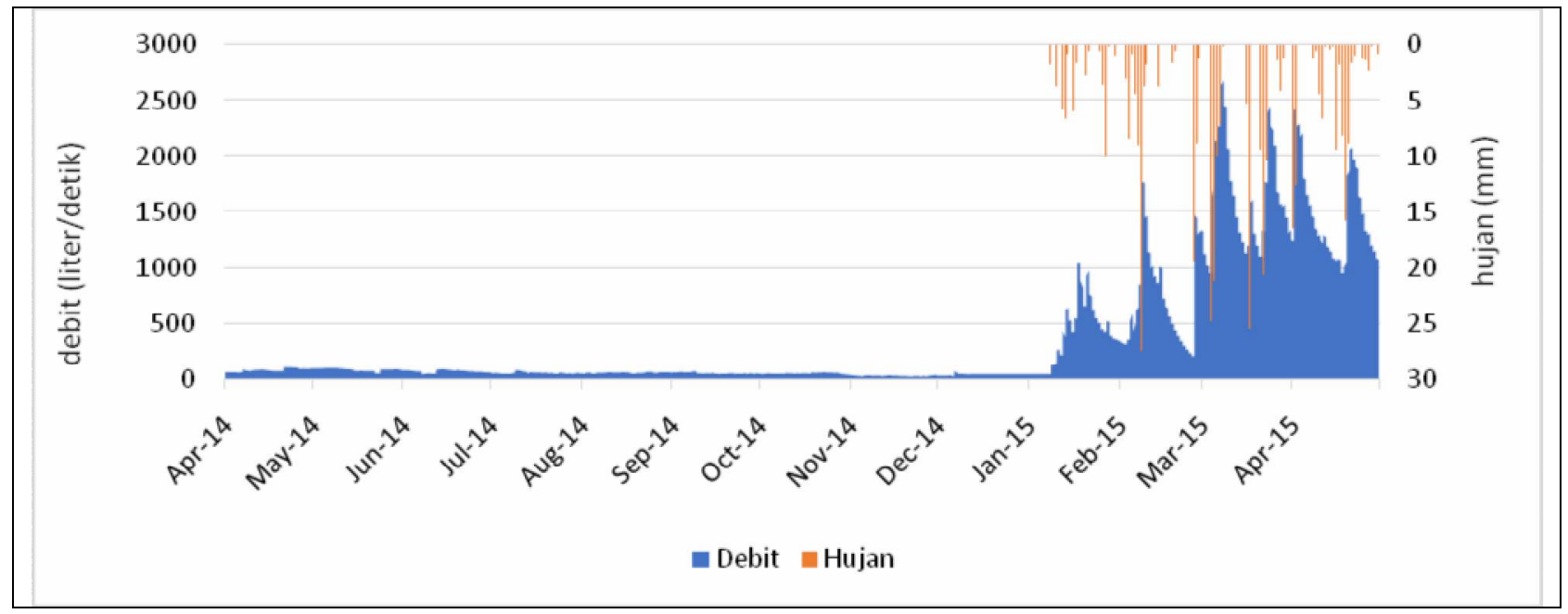

Gambar 5.13. Pasangan data debit aliran dan curah hujan di Mataair Kakap

Gambar 5.13. menunjukkan bahwa musim hujan mulai terjadi pada bulan Januari tahun 2015. Musim hujan pada grafik juga ditandai dengan adanya hidrograf banjir. Hubungan antara debit aliran dan curah hujan tersebut selanjutnya digunakan untuk mengkarakterisasi akuifer karst menggunakan time series analysis. Time series analysis merupakan metode statistik yang dapat digunakan untuk menganalisis respons akuifer karst terhadap hujan. Respons akuifer karst tersebut oleh Zang, dkk (2013) diklasifikasikan menjadi respons terhadap aliran conduit, fissure, dan diffuse. Time series analysis terdiri dari analisis satu variabel (univariate) dan dua variabel (bivariate).

Analisis univariate berupa auto-correlation dengan variabel debit aliran. Sementara itu, analisis bivariate berupa cross-correlation dengan variabel debit aliran dan curah hujan. Kedua metode menganalisis data berdasarkan waktu dan dapat diubah bentuk menjadi analisis frekuensi. Auto-correllation dapat diubah menjadi spectral density. Cross-correlation dapat diubah menjadi cross-amplitude, phase function, coherency function, dan gain function. 


\section{a. Respons Aliran Conduit}

Respons aliran conduit dihitung berdasarkan waktu tunda aliran conduit $\left(\mathrm{T}_{\mathrm{lag}}\right)$ dan durasi maksimum pelepasan aliran conduit. $\mathrm{T}_{\text {lag }}$ didapatkan melalui perhitungan crosscorrelation, phase functions, dan cross-amplitude. Durasi maksimum pelepasan aliran conduit didapatkan melalui perhitungan gain functions. Perhitungan $\mathrm{T}_{\text {lag }}$ menggunakan konsep rising limb, sedangkan durasi maksimum pelepasan aliran conduit menggunakan konsep resesi pada hidrograf banjir.

$\mathrm{T}_{\text {lag }}$ aliran conduit ditunjukkan oleh nilai cross-correlation $\left(\mathrm{C}_{\mathrm{xy}}\right)$ tertinggi. Gambar 5.14 menunjukkan bahwa Mataair Kakap memiliki $\mathrm{C}_{\mathrm{xy}}$ tertinggi dengan nilai 0,155 pada $\mathrm{T}_{\text {lag }} 300$. Hal ini menunjukkan bahwa Mataair Kakap memiliki waktu tunda aliran conduit $\left(\mathrm{T}_{\text {lag }}\right) 300$ menit (5 jam). $\mathrm{T}_{\text {lag }}$ yang bernilai positif (300 menit) juga menunjukkan bahwa debit aliran memiliki hubungan yang berbanding lurus dengan curah hujan.

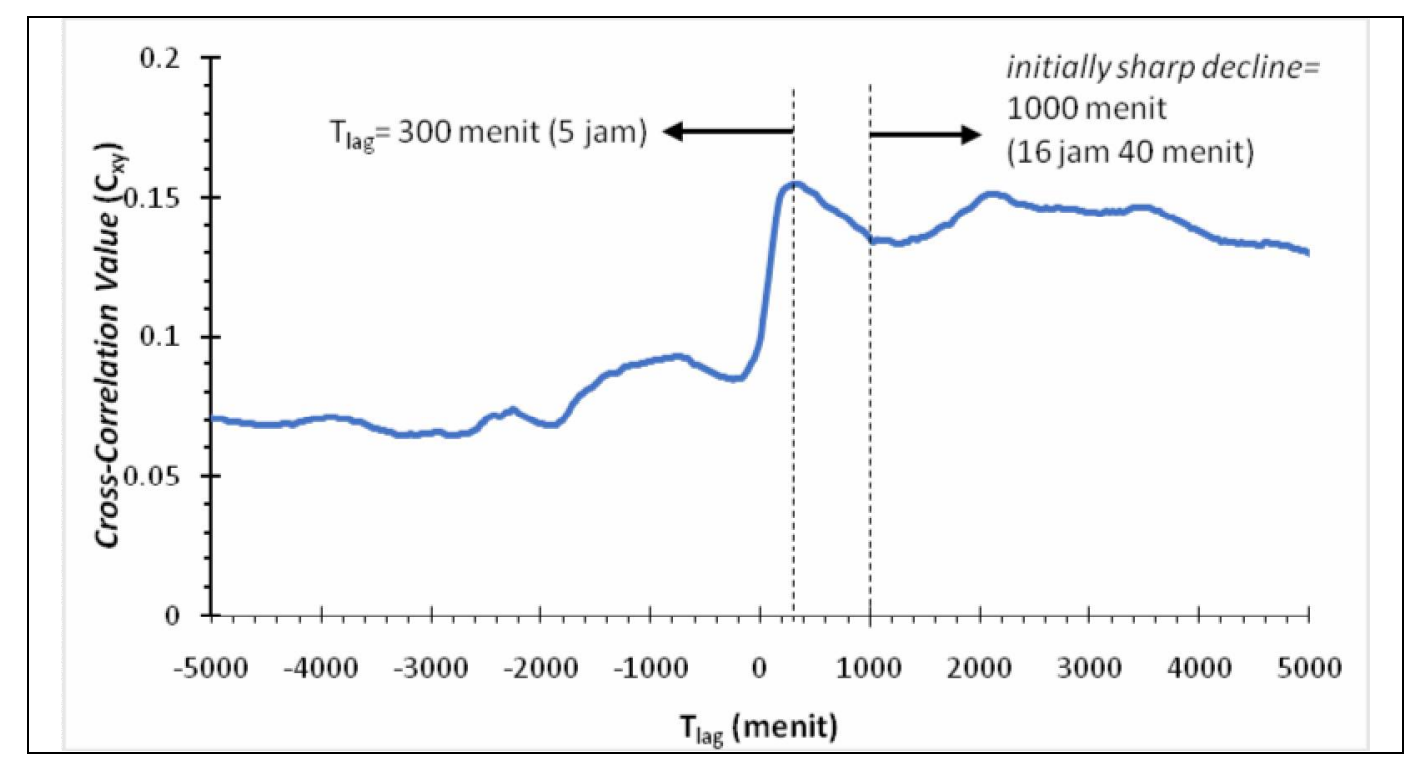

Gambar 5.14. Cross correlation hubungan debit aliran-curah hujan di Mataair Kakap

Phase functions menunjukkan perbedaan frekuensi antara input (hujan) dengan output (debit aliran). Perbedaan ini disebabkan adanya pemfilteran hujan oleh sistem drainase karst (Panagopoulus dan Lambarakis, 2006). Gambar 5.15 menunjukkan bahwa grafik phase functions memiliki bentuk yang konsisten sehingga $\mathrm{T}_{\text {lag }}$ aliran conduit tidak dapat dihitung (Zang, dkk, 2013).

Cross-amplitude $\left(\mathrm{S}_{\mathrm{xy}}\right)$ menunjukkan rerata durasi maksimum pemfilteran input signal (hujan) oleh sistem karst sebelum keluar sebagai output signal (debit aliran). Menurut Zang, dkk 
(2013) nilai tersebut merupakan $T_{\text {lag }}$ maksimum aliran conduit. $T_{\text {lag }}$ maksimum ini didapatkan ketika $S_{x y}$ mendekati nol pada grafik. Mataair Kakap memiliki $S_{x y}$ mendekati nol pada frekuensi $150 \times 10^{-5}$ (Gambar 5.16). Oleh karena itu, lokasi penelitian ini memiliki $\mathrm{T}_{\text {lag }}$ maksimum 667 menit (11 jam 7 menit).

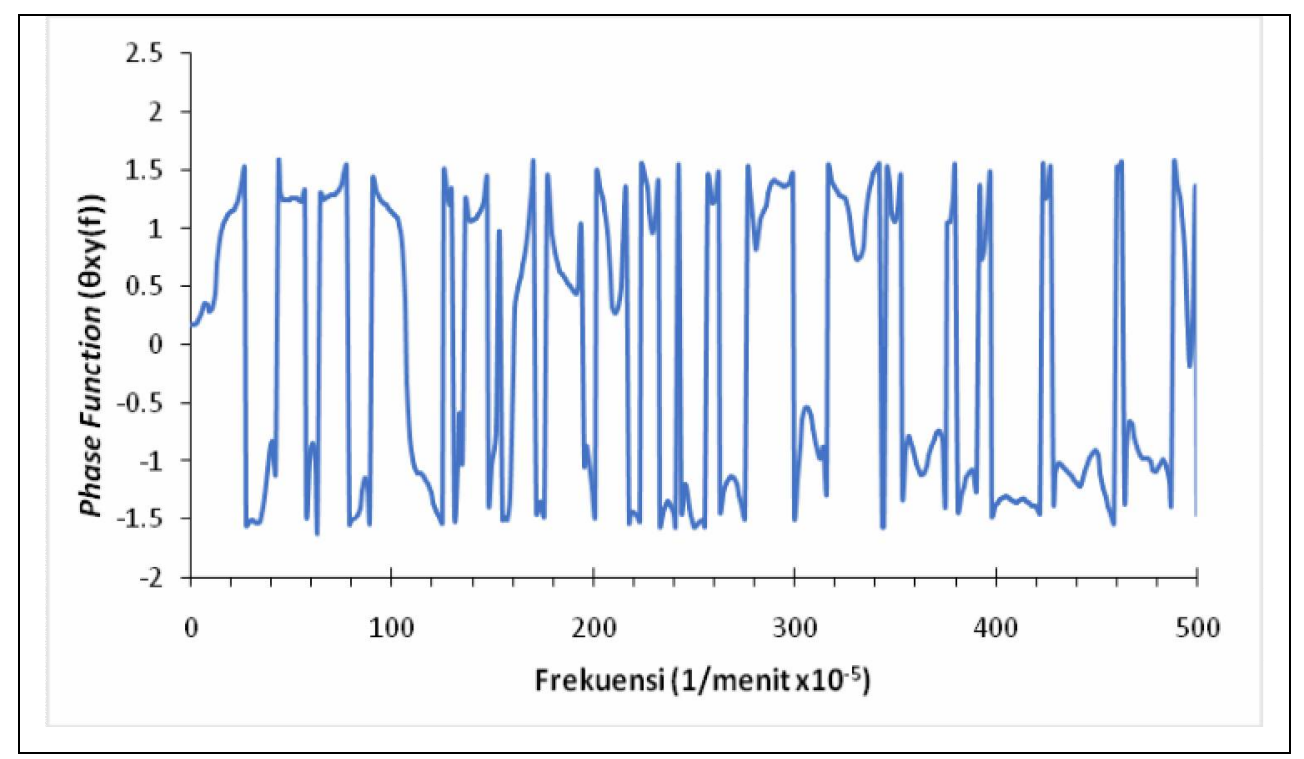

Gambar 5.15. Phase functions hubungan debit aliran-curah hujan di Mataair Kakap

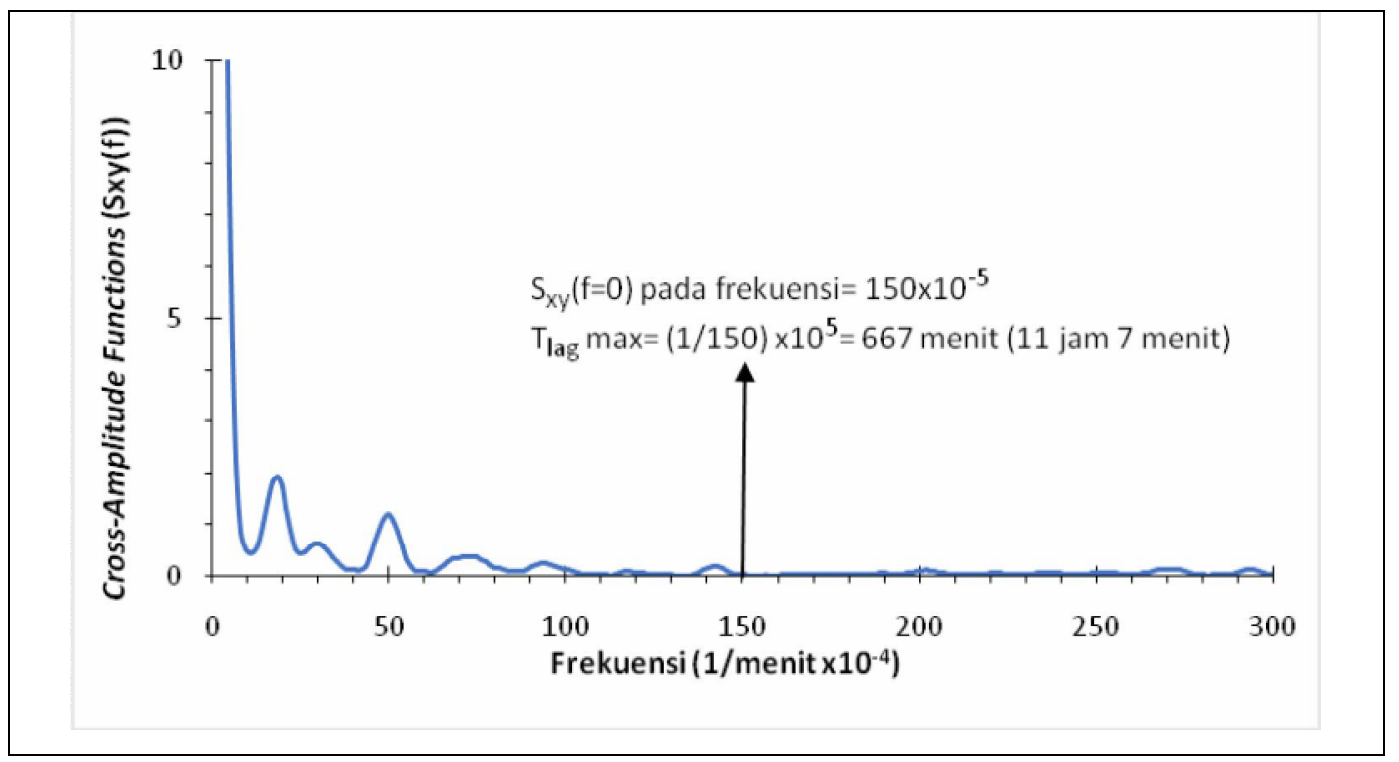

Gambar 5.16. Cross-amplitude hubungan debit aliran-curah hujan di Mataair Kakap

Gain functions $\left(\mathrm{G}_{\mathrm{xy}}\right)$ menunjukkan durasi maksimum pelepasan aliran conduit ketika nilai $\mathrm{G}_{\mathrm{xy}}$ pada grafik memiliki nilai $<0,4$. Angka ini merupakan nilai yang ditetapkan oleh Padilla dan Pulido-Bosch (1995). Mataair Kakap memiliki $G_{x y}$ dengan nilai $<0,4$ pada frekuensi 
$>320 \times 10^{-5}$ (Gambar 5.17). Hal ini menunjukkan bahwa Mataair Kakap memiliki durasi pelepaan aliran conduit <313 menit (5 jam 12 menit).

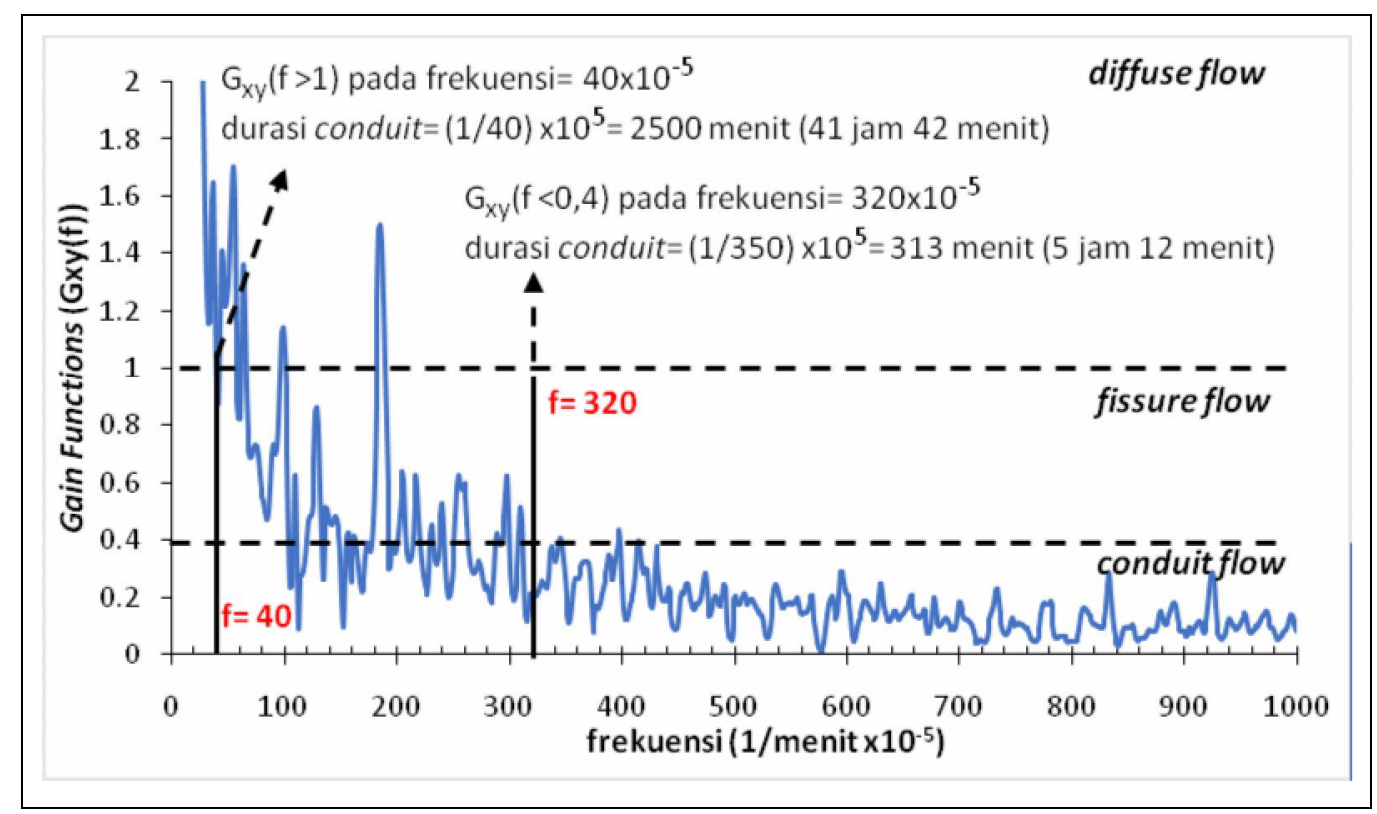

Gambar 5.17. Gain functions hubungan debit aliran-curah hujan Mataair Kakap

\section{b. Respons Aliran Fissure}

Respons sistem drainase karst terhadap aliran fissure dihitung berdasarkan durasi pelepasan aliran fissure dan julat durasi pelepasan aliran fissure. Durasi pelepasan aliran fissure dihitung dengan initially sharp decline pada grafik auto-correlation dan cross-correlation yang menggunakan konsep resesi pada grafik hidrograf banjir. Initially sharp decline pada grafik auto-correlation dan cross-correlation merupakan saat di mana aliran fissure mulai dilepaskan. Mataair Kakap memiliki initially sharp decline pada waktu 1000 menit (Gambar 5.14 dan 5.18). Hal ini menunjukkan bahwa lokasi penelitian memiliki rerata durasi pelepasan aliran fissure 16 jam 40 menit pada perhitungan dengan metode cross-correlation dan auto-correlation. 


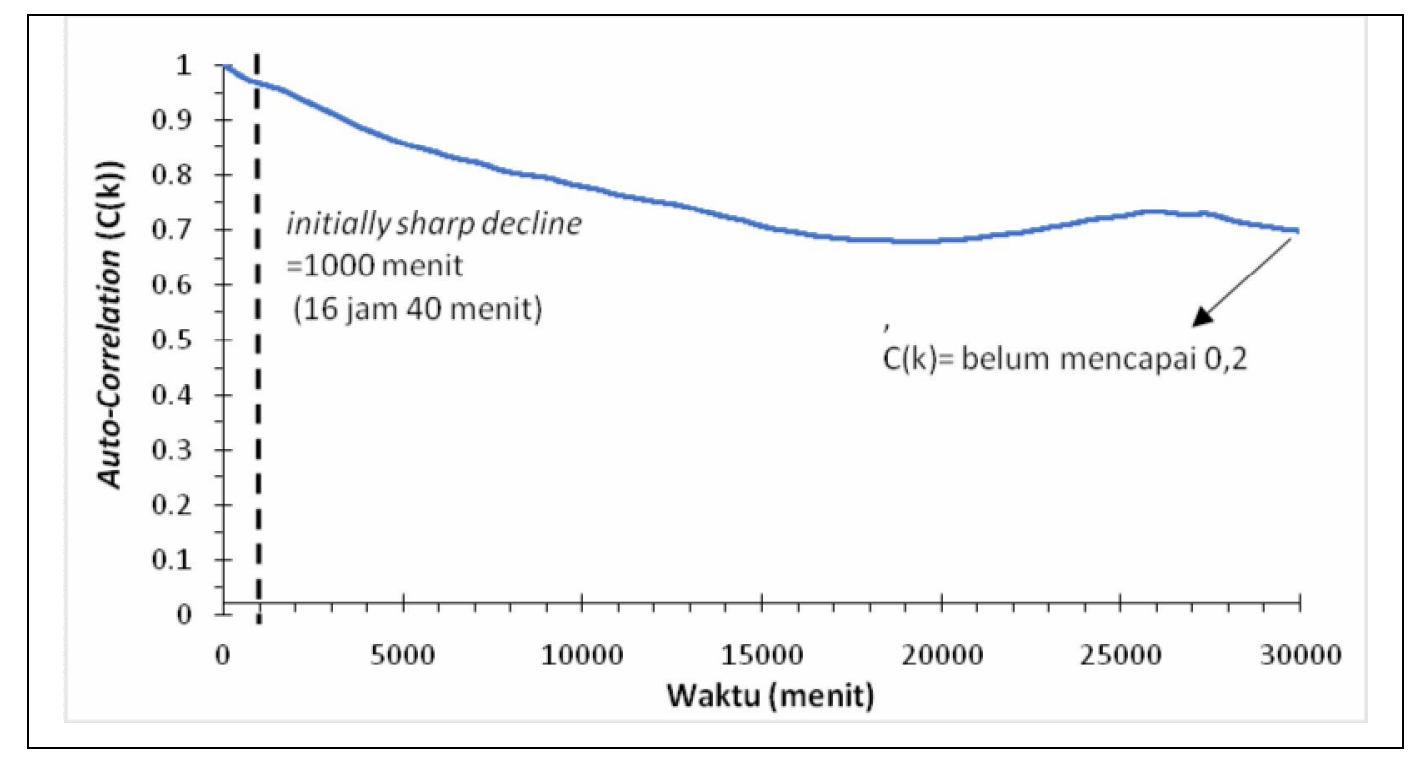

Gambar 5.18. Auto-correlation hubungan debit aliran-curah hujan di Mataair Kakap

Sementara itu, julat durasi pelepasan aliran fissure diperoleh melalui perhitungan gain functions. Gain functions $\left(\mathrm{G}_{\mathrm{xy}}\right)$ menunjukkan julat durasi pelepasan aliran fissure ketika grafik menunjukkan nilai $G_{x y}>0,4$ dan $G_{x y}<1$ atau dapat dituliskan $0,4<G_{x y}<1$. Angka ini merupakan nilai yang ditetapkan oleh Padilla dan Pulido-Bosch (1995). Mataair Kakap memiliki grafik

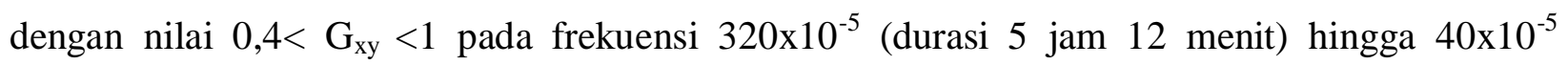
(durasi $=41$ jam 42 menit) yang berarti memiliki julat durasi pelepasan aliran fissure 5 jam 12 menit hingga 41 jam 42 menit (Gambar 5.17).

\section{c. Respons Aliran Diffuse}

Respons akuifer karst terhadap aliran diffuse dihitung berdasarkan durasi pelepasan aliran diffuse dan durasi minimum pelepasan alirannya. Durasi pelepasan aliran diffuse didapatkan melalui perhitungan auto-correlation dan spectral density functions. Kedua perhitungan tersebut menggunakan konsep resesi pada grafik hidrograf banjir. Durasi minimum pelepasan aliran diffuse didapatkan dengan perhitungan gain functions.

Auto-correlation $\left(\mathrm{C}_{(\mathrm{k})}\right)$ menunjukkan rerata durasi pelepasan aliran diffuse dari seluruh kejadian banjir yang terjadi. Rerata durasi tersebut diperoleh ketika nilai $\mathrm{C}_{(\mathrm{k})}$ mencapai predetermined value pada grafik auto-correlation. Menurut Panagopoulus dan Lambrakis (2006), predetermine value adalah kondisi ketika $\mathrm{C}(\mathrm{k})$ mencapai nilai 0,1 hingga 0,3. Gambar 5.18 menunjukkan bahwa grafik Mataair Kakap belum mencapai nilai tersebut pada waktu maksimum 
yang digunakan pada penelitian ini. Oleh karena itu, durasi pelepasan aliran diffuse pada grafik auto-correlation tidak dapat dihitung.

Spectral density (S(f)) juga menunjukkan rerata durasi pelepasan aliran diffuse dari seluruh kejadian banjir yang terjadi (durasi penyimpanan input signal oleh sistem drainase karst) (Larocque, 1998). Rerata durasi tersebut diperoleh ketika nilai S(f) pada grafik spectral density mencapai nilai time regulation $\left(\mathrm{T}_{\mathrm{reg}}\right)$. $\mathrm{T}_{\text {reg }}$ merupakan setengah nilai dari $\mathrm{S}(\mathrm{f})$ pada frekuensi nol (Zang, dkk, 2013). Perhitungan pada Gambar 5.19 menunjukkan bahwa grafik S(f) Mataair Kakap mencapai $\mathrm{T}_{\text {reg }}$ pada frekuensi $3,75 \times 10^{-5}$. Hal tersebut menunjukkan bahwa lokasi penelitian memiliki rerata pelepasan aliran diffuse dengan durasi 26.666 menit (18,5 hari).

Gain functions $\left(\mathrm{G}_{\mathrm{xy}}\right)$ menunjukkan durasi minimum pelepasan aliran diffuse ketika nilai $\mathrm{G}_{\mathrm{xy}}>1$ pada grafik. Angka tersebut merupakan nilai yang ditetapkan oleh Padilla dan PulidoBosch (1995). Mataair Kakap memiliki grafik gain functions dengan nilai $G_{x y}>1$ pada frekuensi 40x $10^{-5}$ (durasi 2500 menit; Gambar 5.17). Hal tersebut memiliki arti bahwa Mataair Kakap memiliki durasi minimum pelepasan aliran diffuse dengan waktu >2500 menit (41 menit 42 jam).

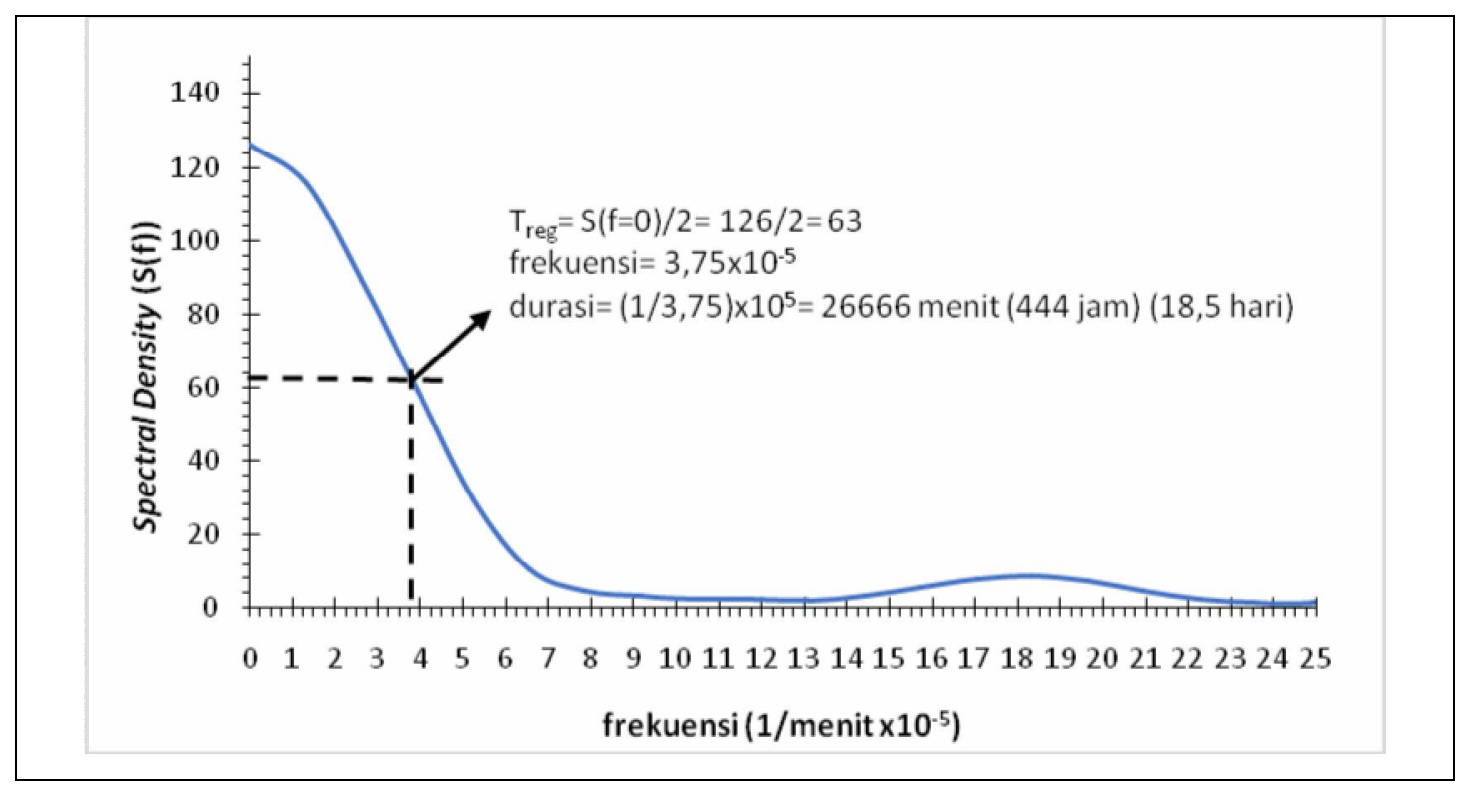

Gambar 5.17. Spectral density hubungan antara debit aliran-curah hujan di Mataair Kakap

Ringkasan perhitungan time series analysis di Mataair Kakap disajikan pada Tabel 5.9. 
Tabel 5.9. Ringkasan perhitungan time series analysis di Mataair Kakap

\begin{tabular}{|c|c|c|c|c|}
\hline Respons & Keterangan & Metode & Indikator & $\begin{array}{l}\text { Time series } \\
\text { analysis (jam) }\end{array}$ \\
\hline \multirow[t]{4}{*}{ Conduit } & Rerata Tlag & Cross-Correlation & $\begin{array}{l}\text { time of correlogram } \\
\text { peak }\end{array}$ & 5 \\
\hline & & Phase Functions & $T \log ={ }_{x y}(f) / /_{\pi f f}$ & - \\
\hline & Tlag max. & Cross-Amplitude & $\begin{array}{l}{[\operatorname{Sxy}(f)] \text { tends to be }} \\
\text { zero }\end{array}$ & $<11,11$ \\
\hline & $\begin{array}{l}\text { Durasi maksimum pelepasan } \\
\text { aliran }\end{array}$ & Gain Functions & $\operatorname{gxy}(f)<0,4$ & $<3,5$ \\
\hline \multirow[t]{3}{*}{ Fissure } & Rerata durasi pelepasan aliran & Auto-Correlation & Initially sharp decline & 16,67 \\
\hline & & Cross-Correlation & Initially sharp decline & 16,67 \\
\hline & Julat durasi pelepasan aliran & Gain Functions & $0,4<\operatorname{gxy}(f)<1$ & $3,5-42$ \\
\hline \multirow[t]{3}{*}{ Diffuse } & Rerata durasi pelepasan aliran & Auto-Correlation & $\mathrm{C}(\mathrm{k})=0,2$ & - \\
\hline & & $\begin{array}{l}\text { Spectral Density } \\
\text { Functions }\end{array}$ & $T_{\text {reg }}=s(f=0) / 2$ & 444 \\
\hline & $\begin{array}{l}\text { Durasi minimum pelepasan } \\
\text { aliran }\end{array}$ & Gain Functions & $\operatorname{gxy}(f)>1$ & $>42$ \\
\hline
\end{tabular}

\subsubsection{Analisis time-series hujan vs aliran di Mataair Sumbersemen}

Data untuk analisis time-series di Mataair Sumbersemen ini menggunakan pasangan data debit aliran dan curah hujan yang dicatat pada setiap interval satu jam. Pencatatan kedua data dilakukan selama sebelas bulan (1 Februari 2016 hingga 22 Desember 2017). Gambar 5.18 menunjukkan pasangan data debit aliran dan curah hujan di Mataair Sumbersemen selama sebelas bulan.

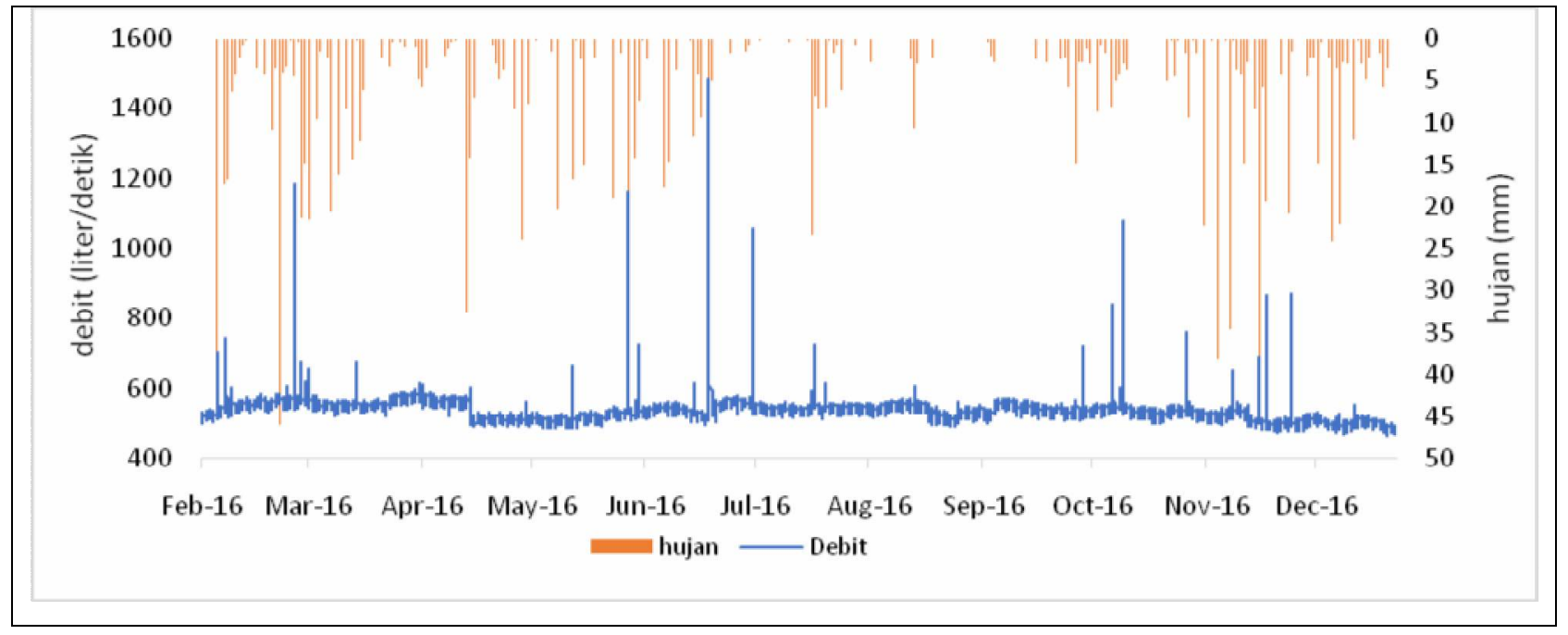

Gambar 5.18. Pasangan data debit aliran dan curah hujan di Mataair Sumbersemen 
Gambar 5.18. menunjukkan adanya anomali, yaitu kejadian banjir selalu terjadi sebelum adanya hujan. Selain itu, beberapa kejadian hujan yang besar tidak menimbulkan banjir. Kondisi ini menunjukkan bahwa stasiun hujan tidak dapat mewakili imbuhan sistem akuifer karst Mataair Sumbersemen. Hal tersebut dapat disebabkan karena akuifer karst memiliki ciri yang unik, di mana porositas sekunder menyebabkan aliran air pada akuifer ini sulit diprediksi.

Time series analysis merupakan metode statistik yang dapat digunakan untuk menganalisis respons akuifer karst terhadap hujan. Respons akuifer karst tersebut oleh Zang, dkk (2013) diklasifikasikan menjadi respons terhadap aliran conduit, fissure, dan diffuse. Time series analysis terdiri dari analisis satu variabel (univariate) dan dua variabel (bivariate). Analisis univariate berupa auto-correlation dengan variabel debit aliran. Sementara itu, analisis bivariate berupa cross-correlation dengan variabel debit aliran dan curah hujan. Kedua metode menganalisis data berdasarkan waktu dan dapat diubah bentuk menjadi analisis frekuensi. Autocorrellation dapat diubah menjadi spectral density. Cross-correlation dapat diubah menjadi cross-amplitude, phase function, coherency function, dan gain function. Adanya anomali pada hubungan data debit aliran dengan curah hujan di Mataair Sumbersemen menjadikan analisis bivariate (cross-correlation beserta turunannya) tidak dapat dilakukan pada penelitian ini.

\section{a. Respons Aliran Conduit}

Respons aliran conduit dihitung berdasarakan waktu tunda aliran conduit $\left(\mathrm{T}_{\text {lag }}\right)$ dan durasi maksimum pelepasan aliran conduit. $\mathrm{T}_{\text {lag }}$ didapatkan melalui perhitungan crosscorrelation, phase functions, dan cross-amplitude. Durasi maksimum pelepasan aliran conduit didapatkan melalui perhitungan gain functions. Perhitungan $\mathrm{T}_{\text {lag }}$ menggunakan konsep rising limb sedangkan durasi maksimum pelepasan aliran conduit menggunakan konsep resesi pada hidrograf banjir.

$\mathrm{T}_{\text {lag }}$ aliran conduit ditunjukkan oleh nilai cross-correlation $\left(\mathrm{C}_{\mathrm{xy}}\right)$ tertinggi. Gambar 5.19 menunjukkan bahwa lokasi penelitian memiliki $\mathrm{C}_{\mathrm{xy}}$ tertinggi dengan nilai 0,214 pada $\mathrm{T}_{\text {lag }}-4$. Nilai tersebut menunjukkan bahwa Mataair Kakap memiliki waktu tunda aliran conduit $\left(\mathrm{T}_{\text {lag }}\right)-4$ jam. $\mathrm{T}_{\text {lag }}$ yang bernilai negatif menunjukkan bahwa debit aliran memiliki hubungan yang berbanding terbalik dengan curah hujan. Hasil ini merupakan bukti bahwa terdapat anomali hubungan antara debit aliran dengan curah hujan. Anomali tersebut menyebabkan tidak dapat dilakukannya perhitungan dengan metode phase functions, cross-amplitude, dan gain functions. 


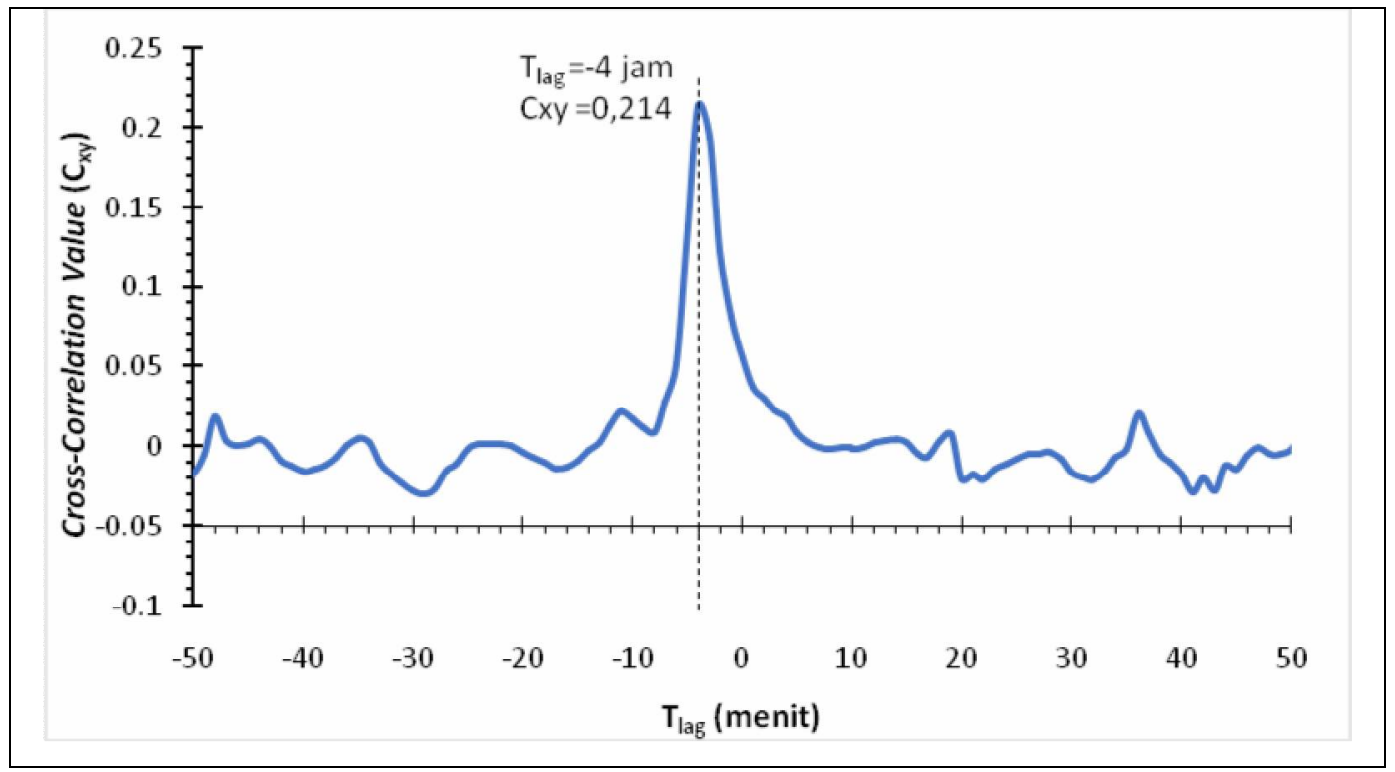

Gambar 5.19. Grafik cross-correlation di Mataair Sumbersemen

\section{b. Respons Aliran Fissure}

Respons akuifer karst terhadap aliran fissure dihitung berdasarkan durasi pelepasan aliran fissure dan julat durasi pelepasan aliran fissure. Durasi pelepasan aliran fissure dihitung dengan initially sharp decline pada grafik auto-correlation dan cross-correlation. Keduanya menggunakan konsep resesi pada grafik hidrograf banjir. Sementara itu, julat durasi pelepasan aliran fissure diperoleh melalui perhitungan gain functions. Perhitungan cross-correlation dan gain functions tidak dapat dilakukan pada penelitian ini karena adanya anomali hubungan antara debit aliran dengan curah hujan. Initially sharp decline pada grafik auto-correlation merupakan saat dimana aliran fissure mulai dilepaskan. Mataair Kakap memiliki initially sharp decline pada waktu 5 jam (Gambar 5.20). Hal ini menunjukkan bahwa lokasi penelitian memiliki rerata durasi pelepasan aliran fissure 5 jam pada perhitungan auto-correlation. 


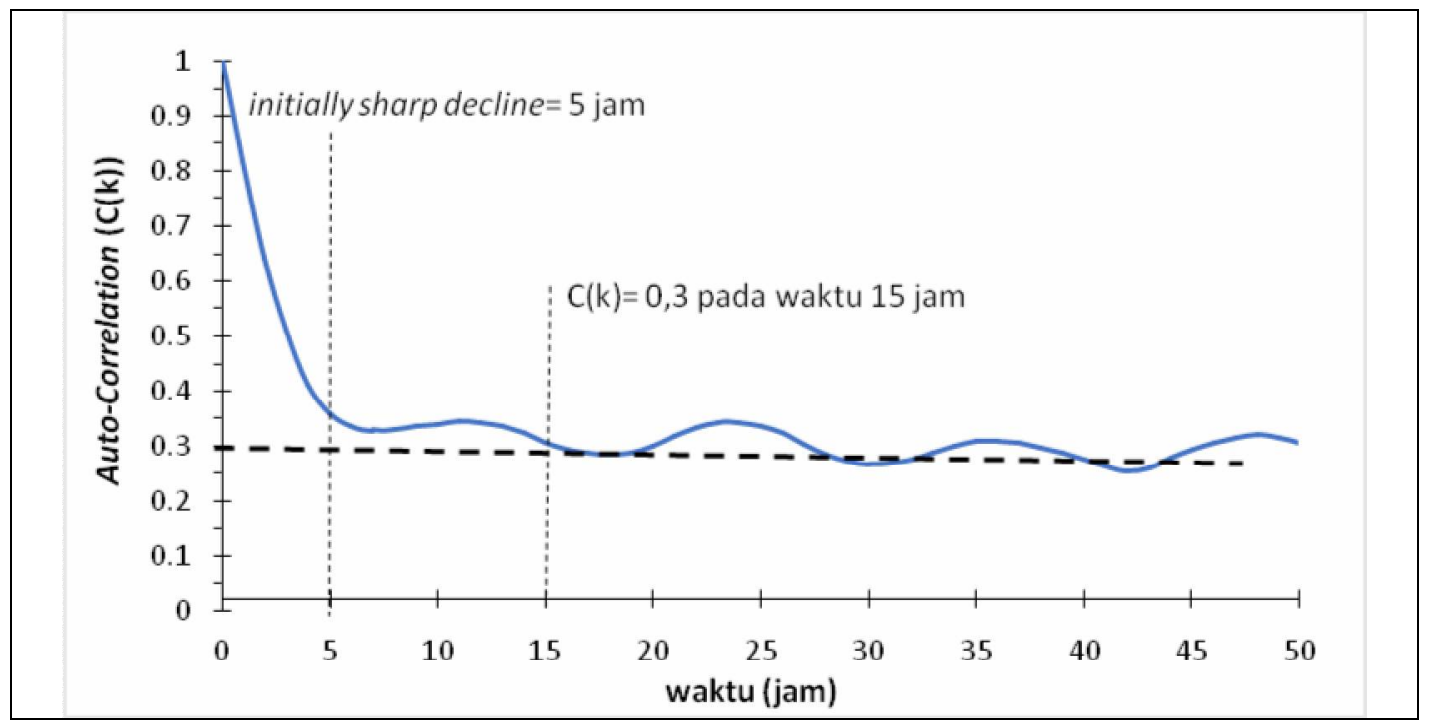

Gambar 5.20. Grafik Auto correlation di Mataair Sumbersemen

\section{c. Respons Aliran Diffuse}

Respons akuifer karst terhadap aliran diffuse dihitung berdasarkan durasi pelepasan aliran diffuse dan durasi minimum pelepasan alirannya. Durasi pelepasan aliran diffuse didapatkan melalui perhitungan auto-correlation dan spectral density functions. Kedua perhitungan tersebut menggunakan konsep resesi pada grafik hidrograf banjir. Durasi minimum pelepasan aliran diffuse didapatkan dengan perhitungan gain functions. Perhitungan gain functions tidak dapat dilakukan pada penelitian ini karena karena adanya anomali hubungan antara debit aliran dengan curah hujan.

Auto-correlation $\left(\mathrm{C}_{(\mathrm{k})}\right)$ menunjukkan rerata durasi pelepasan aliran diffuse dari seluruh kejadian banjir yang terjadi. Rerata durasi tersebut diperoleh ketika nilai $\mathrm{C}(\mathrm{k})$ mencapai predetermined value pada grafik auto-correlation. Menurut Panagopoulus dan Lambrakis (2006), predetermine value adalah kondisi ketika $\left(\mathrm{C}_{(\mathrm{k})}\right)$ mencapai nilai sekitar 0,1 hingga 0,3. Gambar 5.21. menunjukkan bahwa grafik Mataair Kakap mencapai nilai 0,3 pada waktu 15 jam. Oleh karena itu, pelepasan aliran diffuse memiliki durasi rerata 15 jam pada grafik autocorrelation.

Spectral density (S(f)) juga menunjukkan rerata durasi pelepasan aliran diffuse dari seluruh kejadian banjir yang terjadi (durasi penyimpanan input signal oleh sistem drainase karst) (Larocque, 1998). Rerata durasi tersebut diperoleh ketika nilai S(f) pada grafik spectral density mencapai nilai time regulation $\left(\mathrm{T}_{\text {reg }}\right)$. $\mathrm{T}_{\text {reg }}$ merupakan setengah nilai dari $\mathrm{S}(\mathrm{f})$ pada frekuensi nol (Zang, dkk, 2013). Perhitungan pada Gambar 5.21. menunjukkan bahwa grafik S(f) Mataair 
Sumbersemen mencapai $T_{\text {reg }}$ pada frekuensi 0,13. Hal tersebut menunjukkan bahwa lokasi penelitian memiliki rerata pelepasan aliran diffuse dengan durasi 8 jam.

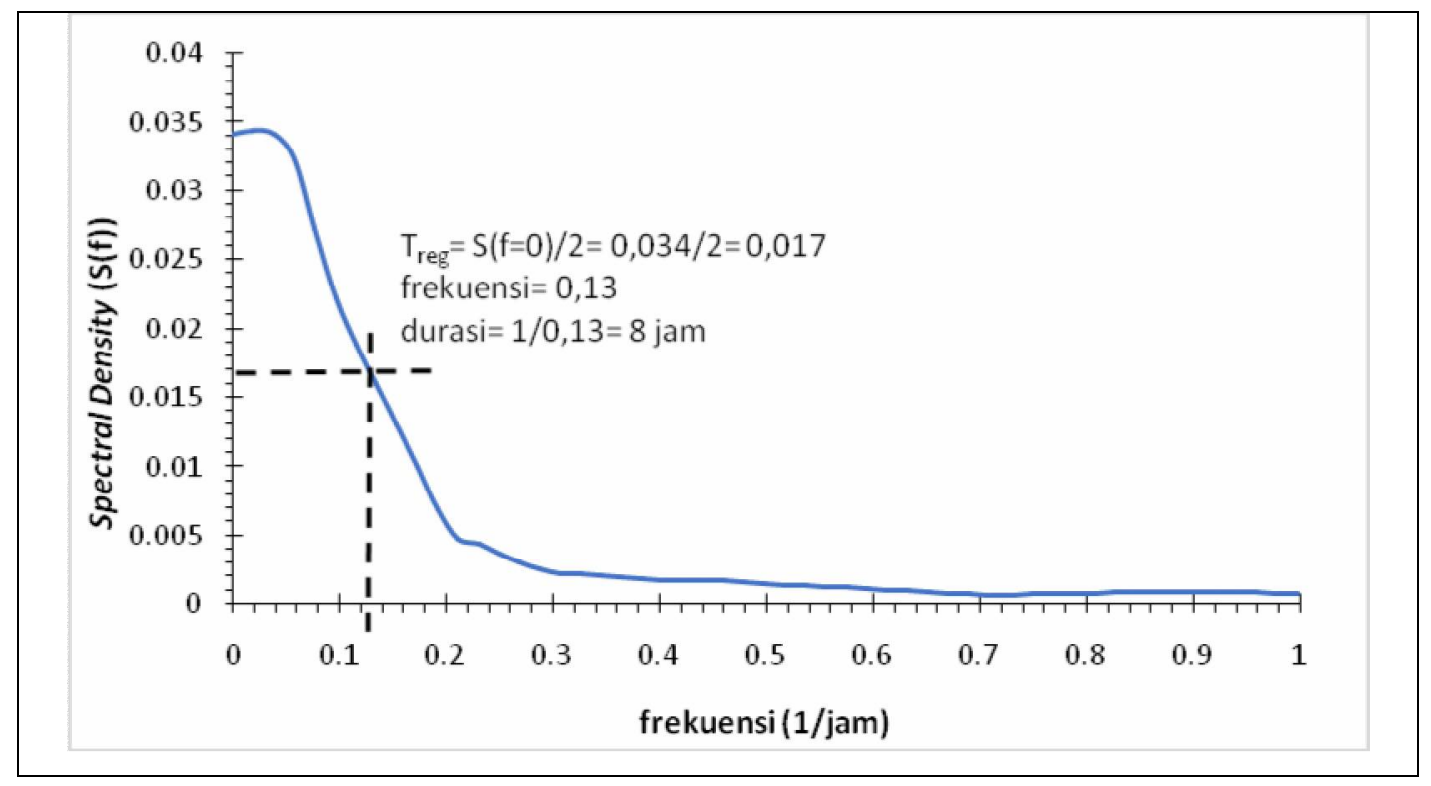

Gambar 5.21. Grafik spectral density di Mataair Sumbersemen

Ringkasan perhitungan time series analysis di Mataair Sumbersemen disajikan pada Tabel 5.10. 
Tabel 5.10. Ringkasan perhitungan time series analysis di Mataair Sumbersemen

\begin{tabular}{|c|c|c|c|c|}
\hline Respons & Keterangan & Metode & Indikator & $\begin{array}{l}\text { Time series } \\
\text { analysis (jam) }\end{array}$ \\
\hline \multirow[t]{4}{*}{ Conduit } & Rerata Tlag & Cross-Correlation & $\begin{array}{l}\text { time of correlogram } \\
\text { peak }\end{array}$ & -4 \\
\hline & & Phase Functions & $\operatorname{Tlag}=\theta_{n g}(f) / 2 \pi f$ & - \\
\hline & Tlag max. & Cross-Amplitude & $\begin{array}{l}{[\operatorname{Sxy}(f)] \text { tends to be }} \\
\text { zero }\end{array}$ & - \\
\hline & $\begin{array}{l}\text { Durasi maksimum pelepasan } \\
\text { aliran }\end{array}$ & Gain Functions & $\operatorname{gxy}(f)<0,4$ & - \\
\hline \multirow[t]{3}{*}{ Fissure } & Rerata durasi pelepasan aliran & Auto-Correlation & Initially sharp decline & 5 \\
\hline & & Cross-Correlation & Initially sharp decline & - \\
\hline & Julat durasi pelepasan aliran & Gain Functions & $0,4<\operatorname{gxy}(\mathrm{f})<1$ & - \\
\hline \multirow[t]{3}{*}{ Diffuse } & Rerata durasi pelepasan aliran & Auto-Correlation & $C(k)=0,2$ & 15 \\
\hline & & $\begin{array}{l}\text { Spectral Density } \\
\text { Functions }\end{array}$ & $I_{r g g}=5(f=0) / 2$ & 8 \\
\hline & $\begin{array}{l}\text { Durasi minimum pelepasan } \\
\text { aliran }\end{array}$ & Gain Functions & $\operatorname{gxy}(f)>1$ & - \\
\hline
\end{tabular}

\subsubsection{Perbandingan nilai hasil time-series analysis antara Mataair Kakap (Karst Gunungsewu-Wonogiri) dan Mataair Sumbersemen (Karst Rembang)}

Ringkasan perbandingan nilai hasil time-series analysis antara Mataair Kakap (Karst

Gunungsewu-Wonogiri) dan Mataair Sumbersemen (Karst Rembang) disajikan pada Tabel 5.11.

Tabel 5.11. Ringkasan perhitungan time series analysis di Mataair Kakap dan Sumbersemen

\begin{tabular}{|c|c|c|c|c|c|}
\hline Respons & Keterangan & Metode & Indikator & $\begin{array}{l}\text { Kakap } \\
\text { (jam) }\end{array}$ & $\begin{array}{l}\text { Sumbersemen } \\
\text { (jam) }\end{array}$ \\
\hline \multirow[t]{4}{*}{ Conduit } & \multirow[t]{2}{*}{ Rerata Tlag } & Cross-Correlation & $\begin{array}{l}\text { time of correlogram } \\
\text { peak }\end{array}$ & 5 & -4 \\
\hline & & Phase Functions & $\operatorname{Tlog}={ }^{\theta_{x y}}(f) / 2 \pi f$ & - & - \\
\hline & Tlag max. & Cross-Amplitude & $\begin{array}{l}{[\operatorname{Sxy}(f)] \text { tends to be }} \\
\text { zero }\end{array}$ & $<11,11$ & - \\
\hline & $\begin{array}{l}\text { Durasi maksimum pelepasan } \\
\text { aliran }\end{array}$ & Gain Functions & $\operatorname{gxy}(f)<0,4$ & $<3,5$ & - \\
\hline \multirow[t]{3}{*}{ Fissure } & \multirow[t]{2}{*}{ Rerata durasi pelepasan aliran } & Auto-Correlation & Initially sharp decline & 16,67 & 5 \\
\hline & & Cross-Correlation & Initially sharp decline & 16,67 & - \\
\hline & Julat durasi pelepasan aliran & Gain Functions & $0,4<\operatorname{gxy}(f)<1$ & $3,5-42$ & - \\
\hline \multirow[t]{3}{*}{ Diffuse } & \multirow[t]{2}{*}{ Rerata durasi pelepasan aliran } & Auto-Correlation & $\mathrm{C}(\mathrm{k})=0,2$ & - & 15 \\
\hline & & $\begin{array}{l}\text { Spectral Density } \\
\text { Functions }\end{array}$ & $T_{r e g}=S(f=0) / 2$ & 444 & 8 \\
\hline & $\begin{array}{l}\text { Durasi minimum pelepasan } \\
\text { aliran }\end{array}$ & Gain Functions & $\operatorname{gxy}(f)>1$ & $>42$ & - \\
\hline
\end{tabular}


Perhitungan time series analysis menunjukkan bahwa Mataair Sumbersemen memiliki respons terhadap aliran conduit, fissure, dan diffuse yang lebih cepat dibandingkan Mataair Kakap (Tabel 5.11). Respons Mataair Sumbersemen terhadap aliran conduit yang lebih cepat ditunjukkan dengan nilai rerata time lag $\left(\mathrm{T}_{\mathrm{lag}}\right)$ dan bentuk grafik cross-correlation (Gambar 5.12). Mataair Sumbersemen memiliki bentuk grafik dengan penurunan yang lebih cepat dibandingkan Mataair Kakap. Sementara itu, $\mathrm{T}_{\text {lag }}$ Mataair Sumbersemen dengan nilai -4 jam lebih cepat dibandingkan Mataair Kakap yang memiliki $\mathrm{T}_{\text {lag }} 5$ jam. $\mathrm{T}_{\text {lag }}$ Mataair Sumbersemen yang negatif (-4) menunjukkan bahwa curah hujan memiliki hubungan yang berbanding terbalik dengan debit aliran. Hal ini mengindikasikan bahwa tidak ada hubungan antara Mataair Sumbersemen dan hujan yang jatuh di daerah yang dipasang alat penakar hujan.

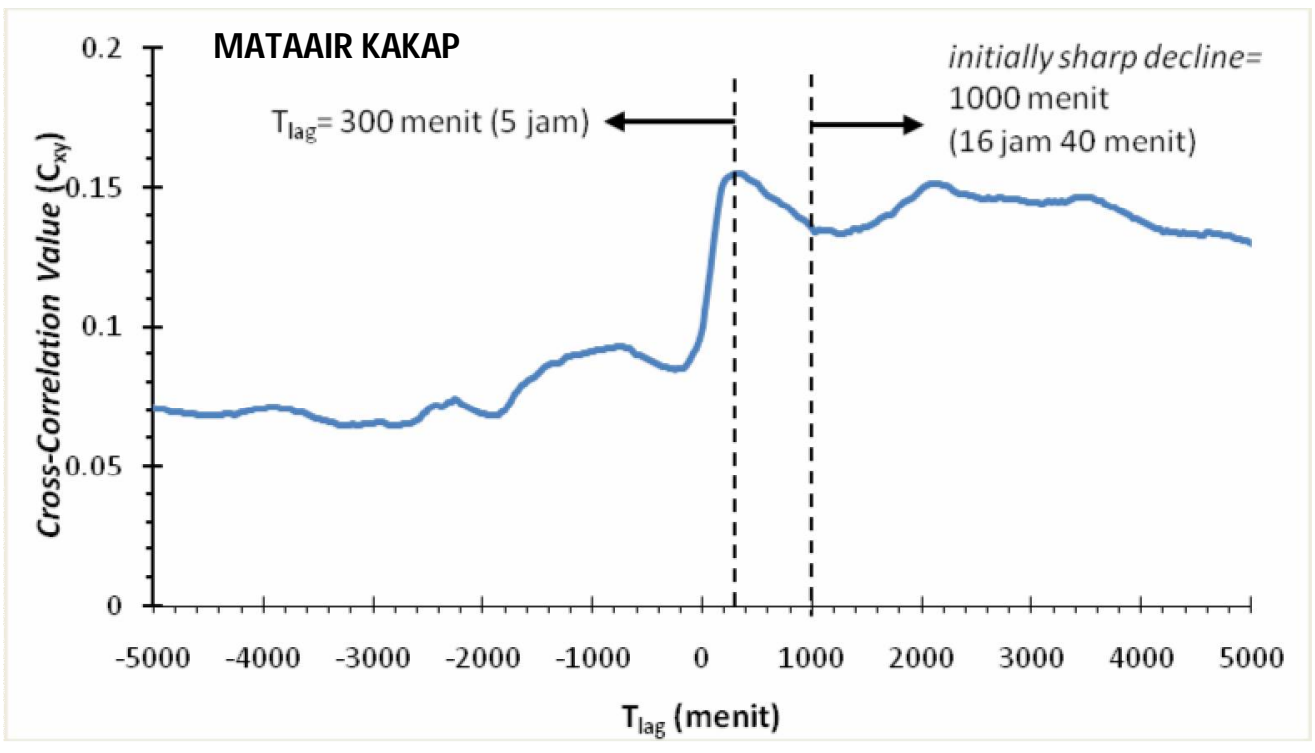




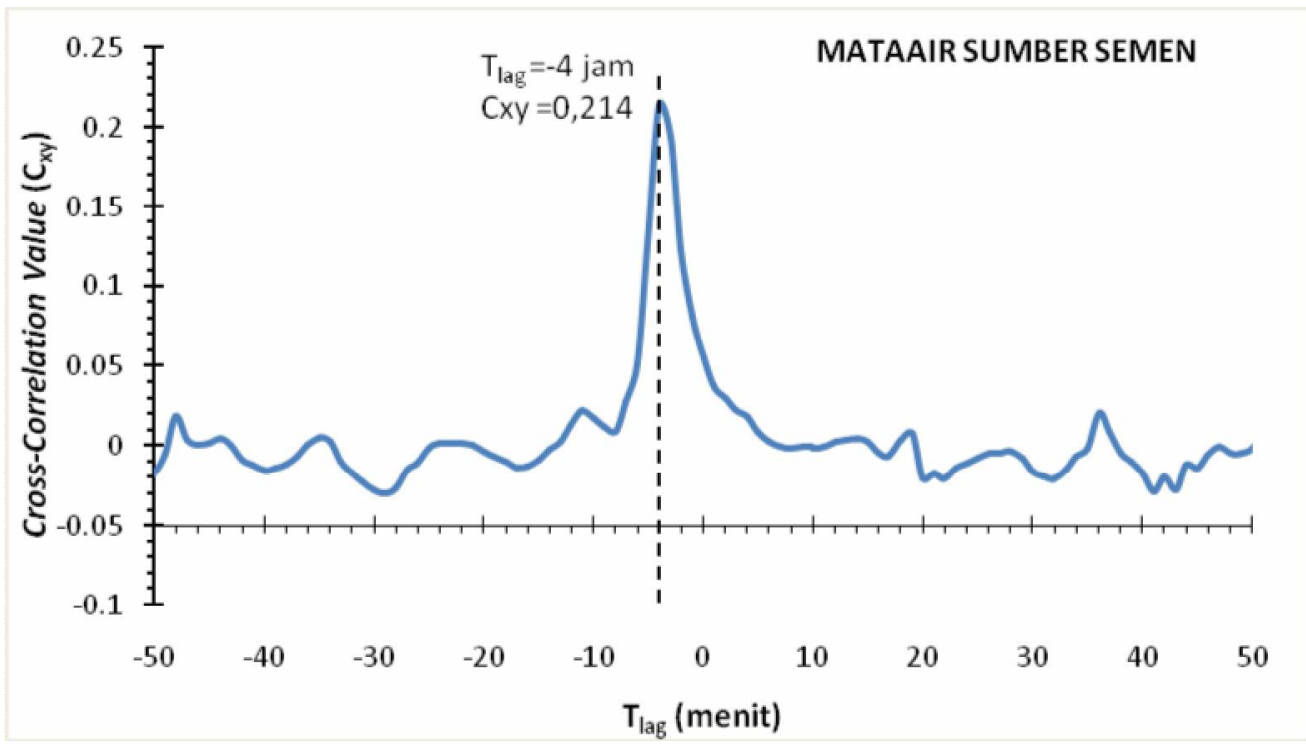

Gambar 5.12. Grafik cross correlation Mataair Sumbersemen dan Kakap

Respons Mataair Sumbersemen terhadap aliran fissure yang lebih cepat ditunjukkan oleh rerata durasi pelepasan aliran fissure. Rerata tersebut dihitung menggunakan initially sharp decline pada grafik auto-correlation (Gambar 5.13). Mataair Sumbersemen memiliki rerata durasi pelepasan aliran fissure (5 jam) yang lebih cepat dibandingkan Mataair Kakap (16,67 jam).

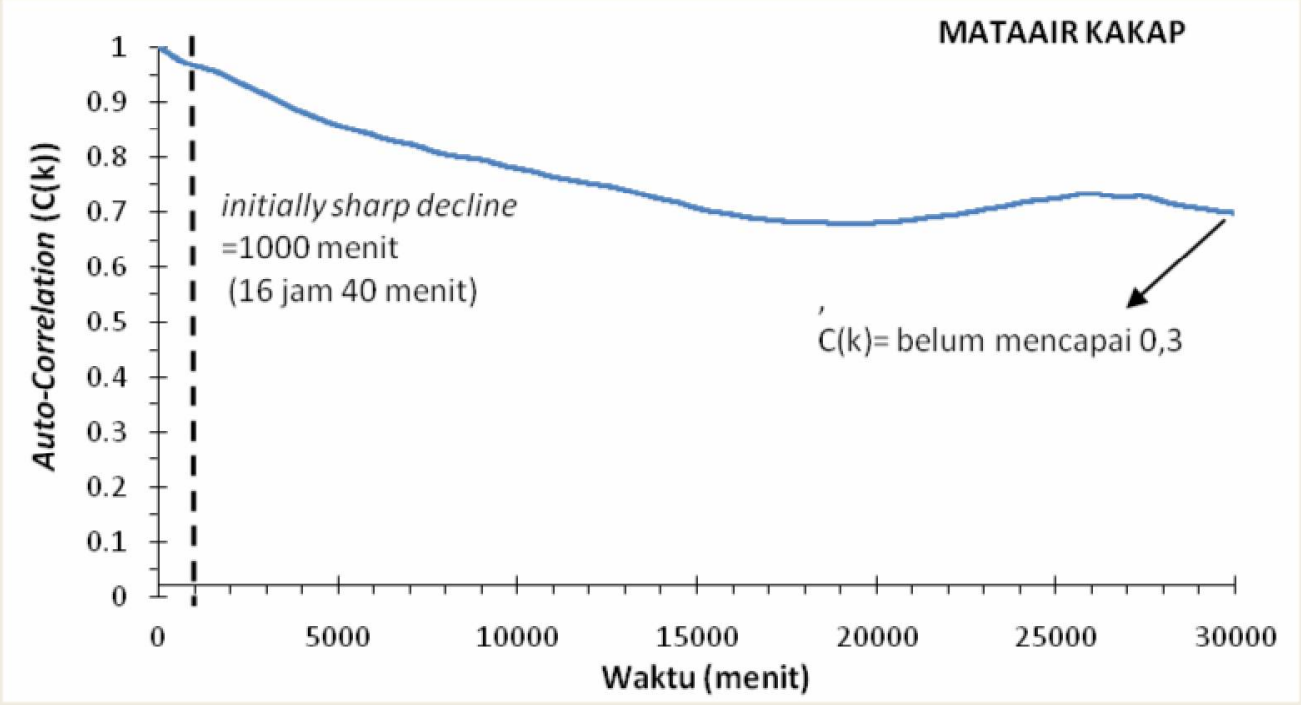




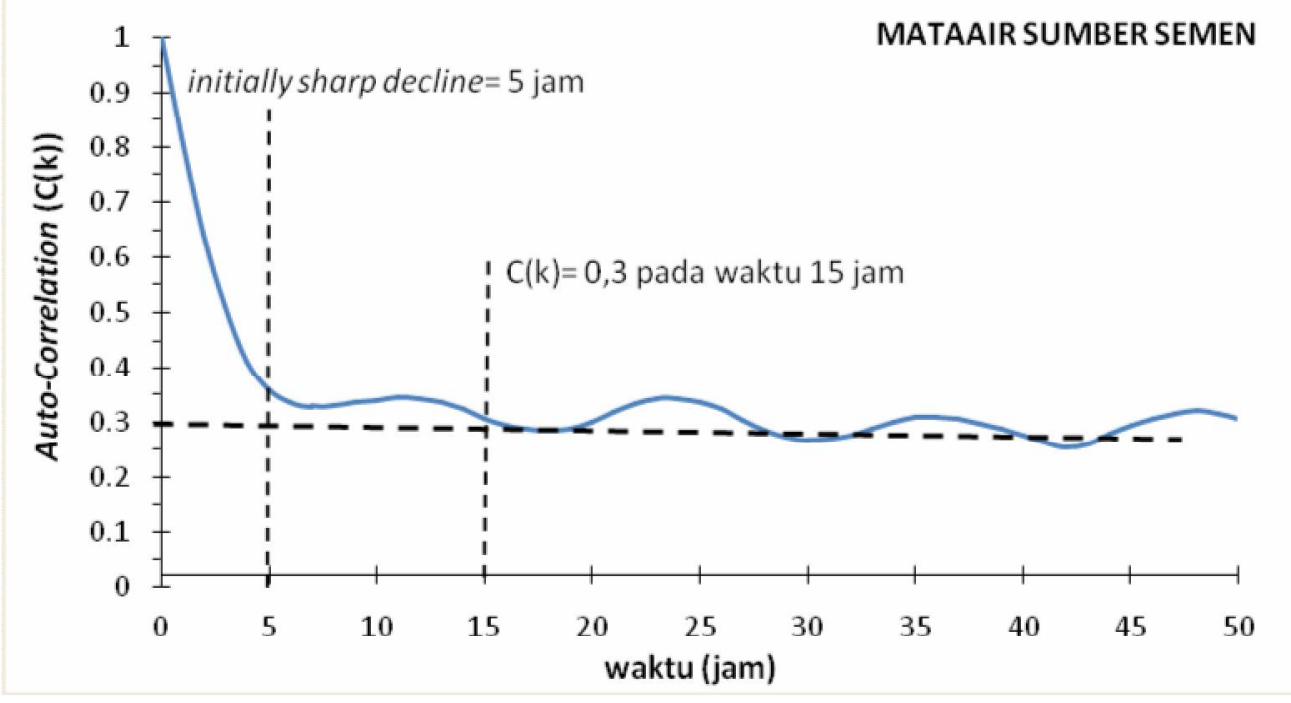

Gambar 5.13. Grafik auto-correlation Mataair Sumbersemen dan Kakap

Respons Mataair Sumbersemen terhadap aliran diffuse yang lebih cepat ditunjukkan oleh rerata durasi pelepasan aliran diffuse. Rerata tersebut dihitung menggunakan $\mathrm{T}_{\text {reg }}$ (time regulation) pada grafik spectral density (Gambar 5.14). Gambar 5.14 menunjukkan bahwa grafik S(f) Mataair Kakap memiliki rerata pelepasan aliran diffuse selama 444 jam. Sementara itu, Mataair Sumbersemen memiliki durasi 8 jam.

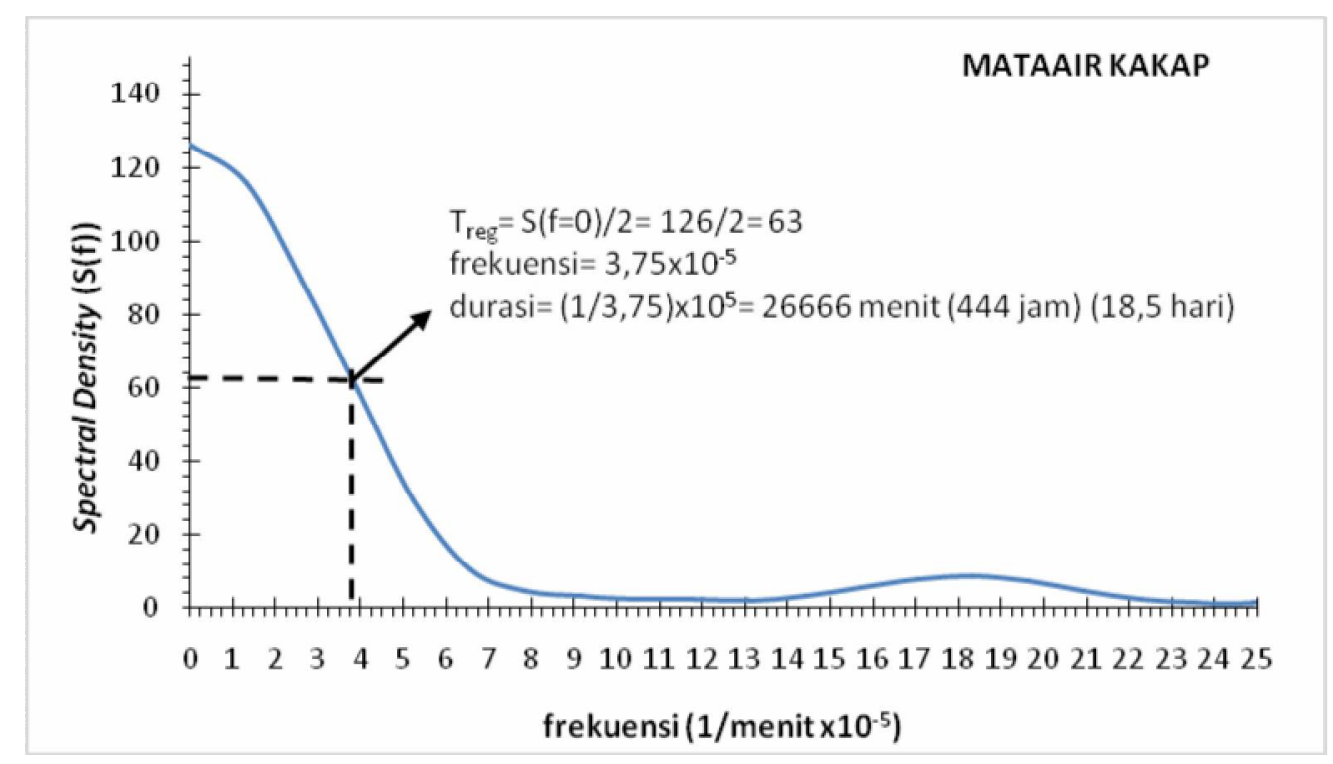




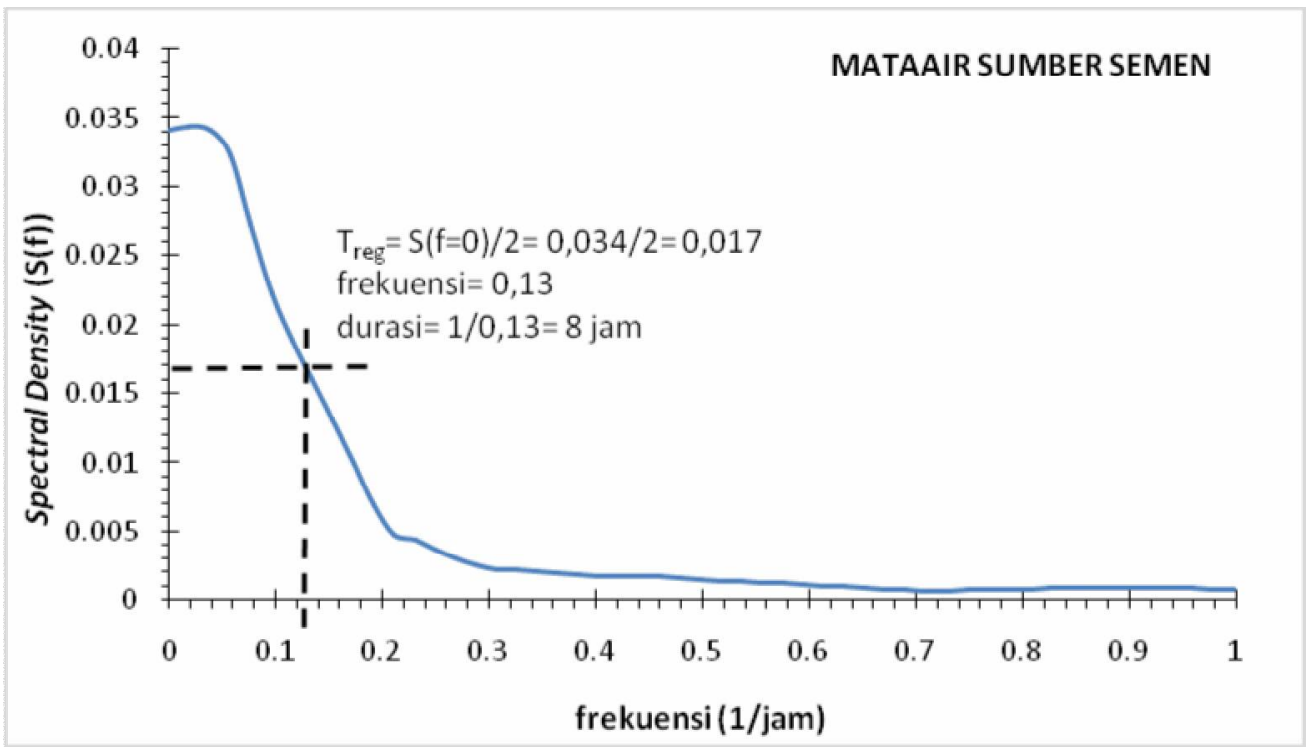

Gambar 5.14. Grafik spectral density Mataair Sumbersemen dan Kakap 


\subsection{Luaran yang dicapai (output)}

Luaran yang telah dicapai pada penelitian ini adalah:

1. Artikel (\#1) ke jurnal internasional yang telah di-accept dan menunggu waktu terbit per 20 Oktober 2017 yang berjudul "Assessment of aquifer karstification degree in some karst sites on Java Island, Indonesia" yaitu ke Jurnal “Carbonates and Evaporites" , ISSN: 0891-2556, Impact Factor 0,375; Penerbit Springer, https://link.springer.com/journal/13146, bukti bisa dilihat di hal Lampiran;

2. Artikel (\#2) ke jurnal internasional yang telah dipublikasi online per tanggal 26 Oktober 2017 yang berjudul "Spatial and Temporal Hydrochemistry Variations of Karst Water in Gunungsewu, Java, Indonesia" yaitu ke Jurnal "Environmental Earth Sciences", ISSN: 1866-6280, Impact Factor 1,765; Penerbit Springer, https://link.springer.com/journal/12655, bukti bisa dilihat di hal Lampiran;

3. Abstract dan full paper yang sudah dikirim ke seminar internasional "The International Conference on Environmental Resources Management in Global Region”, yang akan diadakan pada tanggal 25 November 2017. Judul artikel adalah "Baseflow Index Assessment And Master Recession Curve Analysis For Karst Water Management In Kakap Spring, Gunungsewu”, bukti bisa dilihat di hal Lampiran. 


\section{BAB 6}

\section{RENCANA TAHAPAN BERIKUTNYA}

Penelitian pada tahun ke-2 mempunyai 3 tujuan dengan langkah-langkah:

- Pengambilan sampel air dengan intensitas yang rapat untuk mengkarakterisasi dinamika SKD;

- Pengambilan sampel air hujan untuk uji kualitas air di daerah tangkapan hujan;

- Pengukuran alkalinity, pH, suhu, Daya Hantar Listrik (DHL), dan Eh lapangan;

- Menghitung konstanta resesi dari kurva resesi dengan rumus :

$$
Q_{t}=Q_{0} e^{-\alpha t}
$$

(dimana $Q_{t}$ is adalah debit aliran pada waktu $t, Q_{0}$ adalah debit awal pada segmen resesi, dan $\alpha$ adalah suatu konstanta)

- Analisis pemisahan aliran dasar (baseflow separation) dengan automated base flow separation by digital filtering method (Eckhardt, 2005), rumus yang digunakan adalah :

$$
q_{b(i)}=\frac{\left(1-B F I_{\text {max }}\right) a q_{b(i-1)}+(1-a) B F I_{\text {max }} q_{i}}{1-a B F I_{\text {max }}}
$$

(dimana $q_{b(i)}$ adalah baseflow pada saat $i, q_{b(i-1)}$ adalah baseflow pada waktu sebelumnya $i-1, q_{i}$ adalah total aliran pada waktu $i$, a adalah konstanta resesi dan $B F I_{\max }$ adalah baseflow maksimum yang dapat diukur atau diketahui

- Analisis kimia sampel di laboratorium meliputi kation $\mathrm{Ca}^{2+}, \mathrm{Mg}^{2+}, \mathrm{Na}^{+}, \mathrm{K}^{+}$, dan anion $\mathrm{Cl}^{-}, \mathrm{SO}_{4}{ }^{2-}$, dan $\mathrm{HCO}_{3}{ }^{-}$. Metode analisis yang digunakan meliputi : metode volumetri untuk unsur $\mathrm{Ca}^{2+}, \mathrm{Mg}^{2+}, \mathrm{CO}_{3}{ }^{-}$dan $\mathrm{SO}_{4}{ }^{2-}$; metode spektrofotometri untuk unsur $\mathrm{HCO}_{3}{ }^{-}$; metode flamefotometri untuk unsur $\mathrm{Na}^{+}$dan $\mathrm{K}^{+}$.

- Analisis Charge Balance Calculation, dengan rumus :

$$
\begin{gathered}
\left(\mathrm{Na}^{+}\right)+\left(\mathrm{K}^{+}\right)+2\left(\mathrm{Ca}^{2+}\right)+2\left(\mathrm{Mg}^{2+}\right)=\left(\mathrm{Cl}^{-}\right)+\left(\mathrm{HCO}_{3}{ }^{-}\right)+2\left(\mathrm{SO}_{4}{ }^{2-}\right) \text { sehingga } \\
\sum z m c=\sum z m a
\end{gathered}
$$

(di mana $\mathrm{z}=$ Valensi ion; $\sum \mathrm{Mc}=$ Molalitas kation; $\sum \mathrm{ma}=$ Molalitas anion.

- Analisis Indeks Kejenuhan. Analisis Indeks Kejenuhan atau Saturation Indices (SI) dilakukan untuk mengetahui sifat air sampel terhadap tingkat pelarutan 
batuan karbonat (agresivitas air) terutama terhadap $\mathrm{CaCO}_{3}$, dibantu dengan software Netpath (Plummer, et al., 1991) dengan formulasi sebagai berikut.

$$
\begin{aligned}
& {\left[\mathrm{CO}_{3}{ }^{-}\right]\left[\mathrm{Ca}^{2+}\right]} \\
& \mathrm{SI} \mathrm{CaCO}_{3}=\log 10 \\
& {\left[\mathrm{CO}_{3}{ }^{-}\right]\left[\mathrm{Ca}^{2+}\right]} \\
& \mathrm{Ksp} \mathrm{CaCO}_{3}
\end{aligned}
$$

(dimana $\left[\mathrm{CO}_{3}{ }^{-}\right]$adalah aktivitas ion karbonat; $\left[\mathrm{Ca}^{2+}\right]$ adalah aktivitas ion kalsium; $\mathrm{Ksp}_{\mathrm{CaCO}}$ adalah solubility product kalsit $=10^{-8,48}$ )

- Melakukan analisis bivariate plot (non-discrete parameter), yaitu:(i) hubungan debit-konsentrasi; (ii) hubungan linier antara kalsium dan bikarbonat secara time series pada masing-masing titik sampling: (iii) hubungan DHL-kalsium dan karbonat; (iv) scatter plot natrium dan klorida; (v) hubungan aliran dasar-debit aliran; (vi) hubungan aliran dasar $\log \mathrm{PCO}_{2}$; dan (vii) hubungan aliran dasarkasium dan bikarbonat;

- Melakukan perhitungan kapasitas penyerapan karbon inorganik diperoleh melalui pendekatan dengan metode Standard Limestone Tablets. Metode Standard Limestone Tablets digunakan untuk mengetahui laju pelarutan pada bentanglahan karst. Laju pelarutan dapat diketahui dengan mengetahui selisih berat antara limestone tablets saat belum ditanam dengan limestone tablets setelah ditanam di dalam tanah pada kedalaman 20,50, dan $70 \mathrm{~cm}$ pada lapisan tanah atas.

- menghitung luas daerah tangkapan mataair atau sungai bawah tanah dilakukan dengan rumus imbangan air sederhana yaitu:

$$
(\mathrm{P}-\mathrm{E}) \times \mathrm{A}=\mathrm{Q}
$$

di mana, $\mathrm{P}=$ hujan $(\mathrm{mm}) ; \mathrm{E}=$ evpotranspirasi $(\mathrm{mm}) ; \mathrm{A}=$ luas daerah tangkapan $\left(\mathrm{mm}^{2}\right)$

- $\quad$ menghitung penyerapan karbon di karst dengan rumus Corbel (1956)

$$
\mathrm{V}=\text {-------- }
$$


di mana V: Tingkat pelarutan gamping $\left(\mathrm{m}^{3} /\right.$ year $\left./ \mathrm{km}^{2}\right)$; E : Run off (Hujan-penguapan) dalam desimeter $(\mathrm{dm}) ; \mathrm{T}$ : konsentrasi $\mathrm{CaCO}_{3}$ di mataair karst (mg/l) 
BAB 7

\section{KESIMPULAN DAN SARAN}

\subsection{Kesimpulan}

Dari dua mataair di daerah penelitian (Mataair Kakap-Karst Gunungsewu; dan Mataair Sumbersemen-Karst Rembang) yang telah dianalisis terkait parameterparameter hidrograf banjir dan resesinya, maka terdapat beberapa perbedaan akuifer dalam melepaskan komponen alirannya, yaitu:

a. Mataair Kakap mempunyai tiga tipe aliran yaitu diffuse, fissure, dan conduit. Terkait aliran dasar/diffuse/base flow, mataair ini melepaskan komponen diffuse lebih lambat dari pada akuifer karst di Mataair Sumbersemen. Saat musim hujan, Mataair Kakap merespon aliran conduit dari daerah tangkapan dengan cepat, meskipun masih lebih lambat dibanding yang dijumpai di Mataaair Sumbersemen. Dari beberapa hal tersebut dapat disimpulkan bahwa selain memiliki aliran diffuse yang dominan sepanjang tahun (aliran dasar bulanan hampir mencapai nilai 80\%), akuifer di Mataair Kakap telah memiliki jaringan lorong conduit yang berkembang secara lanjut (aliran dasar saat periode banjir kurang dari $40 \%$ );

b. Mataair Sumbersemen hanya memiliki satu tipe aliran dominan yang diimbuh dari akuifer yaitu tipe aliran diffuse (lambat). Saat musim hujan, respon sangat cepat terhadap hujan kemungkinan berasal dari aliran permukaan (bukan dari simpanan conduit). Hal ini dibuktinya dengan sangat kecilnya aliran dasar saat periode banjir dengan nilai $\mathrm{T}_{\mathrm{p}}$ (time to peak) dan $\mathrm{T}_{\mathrm{b}}$ (time to baseflow) yang sangat singkat. Selain itu, Simpanan aliran dasar yang sangat tinggi sepanjang tahun (99\%), menunjukkan bahwa kemungkinan aliran dasar berasal dari airtanah dalam dan bukan semata-mata dari lorong diffuse.

c. Perhitungan time series analysis menunjukkan bahwa Mataair Sumbersemen memiliki respons terhadap hujan yang lebih cepat dibandingkan Mataair Kakap. Respons Mataair Sumbersemen terhadap aliran conduit yang lebih cepat ditunjukkan dengan nilai rerata time lag $\left(\mathrm{T}_{\mathrm{lag}}\right)$ dan memiliki bentuk grafik dengan penurunan yang lebih cepat dibandingkan Mataair Kakap. Sementara itu, $\mathrm{T}_{\text {lag }}$ Mataair Sumbersemen dengan nilai -4 jam lebih cepat dibandingkan Mataair Kakap yang memiliki $\mathrm{T}_{\text {lag }} 5$ jam. $\mathrm{T}_{\text {lag }}$ Mataair 
Sumbersemen yang negatif (-4) menunjukkan bahwa curah hujan memiliki hubungan yang berbanding terbalik dengan debit aliran. Hal ini mengindikasikan bahwa tidak ada hubungan antara Mataair Sumbersemen dan hujan yang jatuh di daerah yang dipasang alat penakar hujan.

\subsection{Saran}

Penelitian ini masih memerlukan konfirmasi lanjutan, yaitu hubungan antara kondisi hidrogeokimia dan sifat aliran yang in-sya Allah akan dilakukan pada tahun ke-2 penelitian ini. 


\section{DAFTAR PUSTAKA}

Adji TN (2012) Wet season hydrochemistry of Bribin River in Gunung Sewu Karst, Indonesia. Environmental Earth Sciences, 76, 1563-1572.

Adji TN (2013) Hydrogeochemistry and Karst Flow Properties of Bribin River Indonesia, LAP LAMBERT Academic Publishing, Saarbrücken, Germany, 244 p.

Adji TN, Bahtiar IY (2016) Rainfall-discharge relationship and karst flow components analysis for karst aquifer characterization in Petoyan Spring, Java, Indonesia, Environmental Earth Sciences, 75:735

Adji T.N., Misqi M. (2010) The Distribution of Flood Hydrograph Recession Constant for Characterization of Karst Spring and Underground River Flow Components Releasing Within Gunung Sewu Karst Region, Indonesia, Indonesian Journal of Geography, XLII(1), 1-12

Adji, T.N., 2005, Agresivitas Airtanah Karst Sungai Bawah Tanah Bribin, Gunung Sewu, Indonesian Cave and Karst Journal, Vol. 1 No1, HIKESPI

Adji, T.N., 2011, Pemisahan aliran dasar (diffuse flow) hulu daerah tangkapan hujan Sungai Bribin pada aliran Gua Gilap, Karst Gunung Sewu, Gunung Kidul, Yogyakarta, Jurnal Geologi Indonesia, Vol 6, No.3, Sept. 2011

Adji, T.N., 2011, Upper Catchment olu SBT of Bribin Underground River Hydrogeochemistry (Gunung Sewu Karst, Java, Indonesia), Proceeding of Asian Trans-Disciplinary Karst Conference, Jogjakarta, 2011

Adji, T.N., Cahyadi, A., 2016, Pentingnya Monitoring Parameter-Parameter Hidrograf Dalam Pengelolaan Airtanah di Daerah Karst, Seminar Nasional Ekohidrolika APCE-UNESCO, Jogjakarta, 12-14 Oktober 2016

Adji, T.N., Haryono, E., Fatchurrohman, H., Oktama, R., 2015, online first - In press, Diffuse flow characteristics and their relation to hydrochemistry conditions in the Petoyan Spring, Gunungsewu Karst, Java, Indonesia. Geosciences Journal. DOI 10.1007/s12303-015-0048-8

Adji, T.N., Nurjani, E., 1999, Optimasi airtanah karst sebagai pemasok air domestik pada kawasan kritis air di Gunung Kidul, Laporan Penelitian, Fakultas Geografi, Universitas Gadjah Mada, Yogyakarta

Adji, T.N., Rahmawati, N., 2010, The Contribution of $\mathrm{CO}_{2}$ Content in Rainfall to Dissolution Process in Karst Area (Case Study In Bribin Underground River), The Proceeding of Technology cooperation and economic benefit of reduction of GHG emissions in Indonesia" held on 1-2 November 2010 in Hamburg

Cortes, A.F., Cuezva1, S., Anton, E.G., Gallego, M.A., Pla, C., Benavente, D., Canaveras, J.C., Calaforra, J.M., Mattey, D.P., Moral, S.S., 2015, Changes in the storage and sink of carbon dioxide in subsurface atmospheres controlled by climate-driven processes: the case of the Ojo Guaren a karst system, Environ Earth Sciences, 74:7715-7730

Anthony, D.M., Groves, C., Meiman, J., 1997. Preliminary investigations of seasonal changes in the geochemical evolution of Logdson River, Mammoth Cave, Kentucky, Proceedings of the 4th Mammoth Cave Science Conf., Mammoth Cave, KY, 15-23.

Bogli, 1980. Karst Hydrology and Physical Speleology. Springler-Verlag

Bogli, A., 1960. Kalklosung und Karrenbildung.- Z.Geomorph., Suppl.2, Internationale Beitrage zur Karstmorphologie: 4-21. 
Bonacci, O., 1990, Regionalization in karst regions, Proceedings of the Ljubljana Symposium, April 1990, IAHS Publ. no. 191, 1990.

Brunsch, A., Adji, T.N., Ikhwan, M., Stoffel, D., Oberle, P. and Nestmann, F., 2011, Hydrological assessment of a karst area in Southern Java with respect to climate phenomena. Proceedings of Asian Trans-Disciplinary Karst Conference 2011, Jogjakarta, January 7-10, p. 55-68.

Corbel J., 1956, A new method for the study of limestone regions, Revue Canadienne de Geographie, 10, pp. 240-2.

Daoxian Y., 2000, The Carbon Cycle in Karst, IGCP report, Institute of Karst Geology, Guilin.

Delleur, J.,1999, Handbook of Groundwater Engineering. CRC Press LLC, Boca Raton, $1320 \mathrm{p}$.

Domenico,P.A. and Schwartz, F.W., 1990. Physical and Chemical Hydrogeology. $2^{\text {nd }}$ Ed. John Wiley \& Sons

Dreiss, S. J., 1989, Regional scale transport in a karst aquifer: linear systems and time moment analysis. Water Resources Research, 25, 126-134.

Eckhardt, K., 2005, How to construct recursive digital filters for baseflow separation. Hydrological Processes, 19, 507-515.

Eisenlohr L, Bouzelboudjen M, Kiraly L, Rossier Y (1997) Numerical versus statistical modeling of natural response of karst hydrogeological system. J Hydrol (202):244-262.

Etfimi, R., 2005. Use of hydrochemical studies to identify the recharge sources of karst Spring; example of Poceme springs in Albania, Geophysical Research Abstracts, Vol.7, 04063

Fen Huang, F., Zhang, C., Xie, Y., Li, L., Cao, J., 2015, Inorganic carbon flux and its source in the karst catchment of Maocun, Guilin, China, Environmental Earth Sciences, 74:1079-1089

Gillieson, D., 1996, Caves: Processes, Development, and Management, Blackwell, Oxford

Gornitz V., 2008, Ensyclopedia of Paleoclimatology and Ancient Environment, Springer, the Netherlands.

Groves C, and Meiman J., 2001, Inorganic carbonflux and aquifer evolution in the south central Kentucky karst, U.S. Geological Survey Karst Interest Group Proceedings, Water-Resources Investigations Report, 01-4011, pp. 99-105

Han, G., Tang, Y., Wu, Q., 2010, Hydrogeochemistry and dissolved inorganic carbon isotopic composition on karst groundwater in Maolan, southwest China, Environmental Earth Sciences, 60:893-899

Hariadi, B., Adji, T.N., 2009, Variasi Temporal Hidrogeokimia Tetesan dari Ornamen Drapery di dalam Gua Gilap di Kawasan Karst Gunungsewu, Kabupaten Gunungkidul, DIY, Gunung Sewu-Indonesian Cave and Karst Journal, Vol 5 No 1, April 2009

Haryono E, Suratman W, Sriyono, Soenarso S (2001) Pemetaan zonasi kawasan karst di Jawa Timur bagian utara (Kabupaten Tuban). Penelitian kerjasama antara Dinas Pertambangan Propinsi Jawa Timur dengan Fakultas Geografi UGM (in Indonesian).

Haryono, E. , Adji, T.N. 2004. Geomorfologi dan Hidrologi Karst. Yogyakarta : Kelompok Studi Karst Fakultas Geografi UGM. 
Haryono, E. Adji, T.N., Widyastuti, M., Putro, S.T., 2009, Atmospheric Carbon Dioxide Sequestration Trough Karst Denudation Process, Preliminary Estimation From Gunung Sewu Karst, International Seminar on Achieving Resilient-Agriculture to Climate Change Through the Development of Climate-Based Risk Management Scheme, PERHIMPI, Bogor 17-19 Desember 2009

Haryono, E., 2008. Model Perkembangan Karst Berdasarkan Morfometri Jaringan Lembah Di Karangbolong, Gunungsewu. Blambangan dan Rengel, Disertasi, Fakultas Geografi Universitas Gadjah Mada, Yogyakarta

Houghton, R.A., Woodwell, G.M., 1989, Global Climatic Change, Science, Am. 260, 3644

Karami, G.H. and Younger, P.L., 2002, Assessing karst aquifer heterogeneity using testpumping data. Conference on what's new in Groundwater, the Geological Society, London, June 22-23, p. 145-157.

Karimi, H., Raeisi, E., Bakalowicz, M., 2004. Characterising the main karst aquifers of the Alvand Basin, northwest of Zagros, Iran, by a hydrogeochemical approach, Hydrogeology Journal, Vol.13 nr. 5-6

Kresic N, Bonacci O (2010) Spring Discharge Hydrograph. In: Kresic N, Stevanovic Z (eds), Groundwater Hydrology of Springs: engineering, theory, management, and sustainability. Oxford, Butterworth-Heinemann. pp 129-163.

Larocque M, Mangin A, Razack M, Banton O (1998) Contribution of correlation and spectral analyses to the regional study of a large karst aquifer (Charente, France). J Hydrol (205):217-231.

Li, S.L., Liu, C.Q., Lang, Y.C., Tao, F., Zhao, Z., Zhou, Z., 2008, Stable Carbon Isotope Biogeochemistry and Anthropogenic Impacts on Karst Ground Water, Zunyi, Southwest China, Aquatic Geochemistry, 14:211-221

Liu, Z. , Zhao J., 2000, Contribution of carbonate rock weathering to the atmospheric $\mathrm{CO}_{2}$ sink. Environmental Geology. 39, pp. 1053-1058.

Liu, Z.,Groves,C., Yuan,D., Meiman, J., 2004(a). South China Karst Aquifer StormScale Hydrochemistry, Ground Water. 42, Jul/Agt 2004

Liu, Z.,Groves,C., Yuan,D., Meiman,J., Jiang, D., He, S., Li,Q., 2004(b). Hydrochemical variation during flood pulses in the south-west peak cluster karst : impacts of $\mathrm{CaCO}_{3}-\mathrm{H}_{2} \mathrm{O}-\mathrm{CO}_{2}$ interactions, Hydrological Processess. 18, 2423-2437

Mackenzie F.T., Lerman A., and Andersson A.J. 2004, Past and present of sediment and carbon biogeochemical cycling models, Biogeosciences, 1, pp. 11-32.

Malik P (2007) Assessment of regional kastification degree and groundwater sensitivity to pollution using hydrograph analysis in the Velka Fatra Mountains, Slovakia. Environ Geol (51):707-711.

Malik P, Vojtkova S (2010) Use of combined recession curve analysis of neighbouring karstic springs to reveal karstification degree of groundwater springing routes. In: Andreo B, Carrasco F, Durán JJ, LaMoreaux JW (eds) Advances in Research in Karst Media. Springer-Verlag Berlin Heidelberg, Berlin, pp 101-106

Malik P, Vojtkova S (2012) Use of recession-curve analysis for estimation of karstification degree and its application in assessing overflow/underflow conditions in closely spaced karstic springs. Environ Earth Sci (65):2245-2257

Martin, J.B., Wicks, C.M. Sasowky, J.D. 2002. Interaction of Fracture and Conduit Flow in the Evolution of Karst Aquifers, Hydrogeology and Biology of Past-Paleozoic Carbonate Aquifers. KWI Special Publ. 7., Charles Town, Virginia 
Mohammadi Z, Shoja A (2014) Effect of annual rainfall amount on characteristics of karst spring hydrograph. Carbonates and Evaporites, 29 (3). pp 279-289

Mudry, J., 2004. Hydrochemical Characterization of Karst Aquifers, University of Franche-Comté, BESANÇON, France Page 2. http://lsbb.unice.fr/sms_us/Mudry.pdf

Noya Y, Suwarti T, Suharsono, Sarmili L (1992) Geological map of The Mojokerto quadrangle, Jawa. Geological Research and Development Centre, Bandung, Indonesia.

Padilla A, Pulido-Bosch A (1995) Study of hydrographs of karstic aquifers by means of correlation and cross-spectral analysis. J Hydrol (168):73-89

Panagopoulos G, Lambrakis N (2006) The contribution of time series analysis to the study of the hydrodynamic characteristics of the karst system: Application on two typical karst aquifers of Greece (Trifilia, Alymros Crete). J Hydrol (329):368-376.

Parry M.L., Canziani O.F., Palutikof J.P. and Co-authors 2007: Technical Summary. Climate Change 2007: Parry, O.F. Canziani, J.P. Palutikof, P.J. van der Linden and C.E. Hanson, M.L. (Eds.), Impacts, Adaptation and Vulnerability. Contribution of Working Group II to the Fourth Assessment Report of the Intergovernmental Panel on Climate Change, Cambridge University Press, Cambridge, UK, pp. 23-78.

Quinlan JF (1989) Ground-water monitoring in karst terraces: recommended protocols and implicit assumptions. US Environmental Protection Agency Environmental Monitoring Systems Laboratory, Las Vegas.

Quinlan JF, Smart PL, Schindel GM, Alexander EC, Edwards AJ, Smith AR (1991) Recommended administrative/regulatory definitions of karst aquifer. Principles for classification of carbonate aquifers. Practical evaluation of vulnerability of karst aquifers and determination of optimum sampling frequency at springs. In: Quinlan JF, Stanley A (eds), Hydrology, ecology, monitoring and management of ground water in karst terraces conference, 3rd, Proceedings: Dublin, Ohio, National Ground Water Association, pp 573-635.

Raeisi, R., Karami,G., 1997. Hydrochemographs of Berghan karst spring as indicators of aquifer characteristics, Journal of Cave and Karst Studies 59(3), 112-118

Rahnemaei M, Zare M, Nematollahi AR, Sedghi H (2005). Application of spectral analysis of daily water level and spring discharge hydrographs data for comparing physical characteristics of karstic aquifers. J Hydrol (311):106-116.

Rashed KA (2012) Assessing degree of karstification: a new method of classifying karst aquifers. Sixteenth International Water Technology Conference, Istanbul, April 12-15, p. 121-129.

Schulz, E.F., 1976, Problems in Applied Hydrology. Water Resources Publication, Colorado, $508 \mathrm{p}$.

Shuster, E.T. , White, W.B., 1971. Seasonal fluctuations in the chemistry of limestone springs: A possible means for characterizing carbonate aquifers. Journal of Hydrology 14: 93-128.

Smart, P.L. and Hobbes, S.L., 1986. Characteristics of Carbonate Aquifers: A conceptual basis. In Proceedings, Environmental Problem in Karst Terrains and Their Solution. Bowling Green, KY: National Well Water Association, 1-4

Susilohadi (1995) Late tertiary and quarternary geology of the East Java Basin, Indonesia. Dissertation, School of Geosciences, University of Wollongong 
Sweeting, M.M., 1972. Karst Landforms, Macmillan, London.

Taylor, J.T., Greene, E.A.2001. Quantitative Approaches in Characterizing Karst Aquifers, in Eve L. Kuniansky, ed., USGS Karst Interst Group Proceedings, Water Resources Investigation Report 01-4011, p. 164-166.

Trudgil, S., 1985. Limestone Geomorphology, Longman, New York.

Valdes D, Dupont JP, Massei N, Laignel B, Rodet J (2006) Investigation of karst hydrodynamics and organization using autocorrelation and $\mathrm{T}-\Delta \mathrm{C}$ curves. $\mathrm{J}$ Hydrol (329):432-443.

Wang,Y., Ma, T., Luo,Z., 2001. Geostatistical and geochemical analysis of surface water leakage into groundwater on a regional scale: a case study in the Liulin karst system, northwestern China, Journal of Hydrology 246, 223-234

White WB (2002) Karst hydrology: recent development and open question. Eng Geol (65):85-105.

White, W.B., 1988, Geomorphology and Hydrology of Karst Terrains, New York: Oxford University Press, London.

Zhang, Z., Chen, Xi, Chen X., Shi, P., 2013, Quantifying Time Lag of Epikarst-Spring Hydrograph Response to Rainfall Using Correlation and Spectral Analyses. Hydrogeology Journal, 21, 1619-631. 


\section{LAMPIRAN BUKTI CAPAIAN}

Lampiran 1. FORMULIR EVALUASI ATAS CAPAIAN LUARAN KEGIATAN

Lampiran 2. Bukti submit artikel dan artikel yang yang telah di-submit ke jurnal internasional

Lampiran 3. Bukti submit abstract dan full paper ke seminar internasional

Lampiran 4. SK Pembimbing Tim Mahasiswa Pasca Sarjana 


\section{Lampiran 1.}

\section{FORMULIR EVALUASI ATAS CAPAIAN LUARAN KEGIATAN}

Ketua

Perguruan Tinggi

Judul

Waktu Kegiatan
: Dr. Tjahyo Nugroho Adji, MSc.Tech

: Universitas Gadjah Mada

: Model Tingkat Perkembangan Pelorongan Akuifer Karst Untuk Identifikasi Kapasitas Penyerapan Karbon Sebagai Antisipasi Bencana Pemanasan Iklim Global : tahun ke 1 (satu) dari rencana 3 (tiga) tahun

\begin{tabular}{|c|l|l|}
\hline No & \multicolumn{1}{|c|}{ Luaran yang direncanakan tahun ke-1 } & \multicolumn{1}{c|}{ Capaian } \\
\hline 1 & Artikel publikasi ke jurnal internasional & $\begin{array}{l}\text { Tercapai, sudah terbit pada } 2 \\
\text { jurnal internasional }\end{array}$ \\
\hline 2. & Menjadi pembicara di seminar internasional & $\begin{array}{l}\text { Tercapai, dan sudah submit } \\
\text { abstract dan full paper sesuai } \\
\text { jadwal dari panitia }\end{array}$ \\
\hline \multicolumn{3}{|c|}{ Bukti terlampir } \\
\hline
\end{tabular}

\section{PUBLIKASI ILMIAH}

\begin{tabular}{|l|l|}
\hline Artikel jurnal ke-1 & \multicolumn{1}{|c|}{ Keterangan } \\
\hline Nama jurnal yang dituju & Environmental Earth Sciences, ISSN: 1866-6280 \\
\hline Klasifikasi jurnal & Jurnal internasional - Q1 \\
\hline Impact factor jurnal & 1,765 \\
\hline Judul artikel & $\begin{array}{l}\text { Spatial and Temporal Hydrochemistry Variations of } \\
\text { Karst Water in Gunungsewu, Java, Indonesia }\end{array}$ \\
\hline Status naskah & - \\
\hline Draft artikel & - \\
\hline Sudah dikirim ke jurnal & - \\
\hline Sedang ditelaah & - \\
\hline Sedang di-revisi & $\mathbf{( 3 1}$ Agustus 2017) \\
\hline Revisi sudah dikirim ulang & $\mathbf{1 5}$ Oktober 2017 (Accepted) \\
\hline Sudah diterima & $\mathbf{2 6}$ Oktober 2017 (published online) \\
\hline Sudah terbit & \multicolumn{1}{|c|}{ Keterangan } \\
\hline \multicolumn{2}{|l|}{ Carbonates and Evaporites, ISSN: 0891-2556 } \\
\hline Artikel jurnal ke-2 & Jurnal internasional - Q3 \\
\hline Nama jurnal yang dituju & 0,375 \\
\hline Klasifikasi jurnal & $\begin{array}{l}\text { Assessment of aquifer karstification degree in some karst } \\
\text { sites on Java Island, Indonesia }\end{array}$ \\
\hline Impact factor jurnal & \multicolumn{1}{|l}{} \\
\hline Judul artikel &
\end{tabular}




\begin{tabular}{|l|l|}
\hline Draft artikel & - \\
\hline Sudah dikirim ke jurnal & - \\
\hline Sedang ditelaah & - \\
\hline Sedang di-revisi & - \\
\hline Revisi sudah dikirim ulang & (7 Agustus 2017) \\
\hline Sudah diterima & 15 Oktober 2017 (Accepted) \\
\hline Sudah terbit & - \\
\hline
\end{tabular}

\section{BUKU AJAR}

\begin{tabular}{|c|c|}
\hline Buku ke-1 & Keterangan \\
\hline Judul & - \\
\hline Penulis & - \\
\hline Penerbit & - \\
\hline
\end{tabular}

\section{PEMBICARA PADA PERTEMUAN ILMIAH (SEMINAR)}

\begin{tabular}{|l|l|l|}
\hline & Nasional & \multicolumn{1}{|c|}{ Internasional } \\
\hline Judul makalah & - & $\begin{array}{l}\text { Baseflow Index Assessment And Master } \\
\text { Recession Curve Analysis For Karst } \\
\text { Water Management In Kakap Spring, } \\
\text { Gunungsewu }\end{array}$ \\
\hline Nama pertemuan ilmiah & - & $\begin{array}{l}\text { The International Conference on } \\
\text { Environmental Resources Management in } \\
\text { Global Region }\end{array}$ \\
\hline Tempat pelaksanaan & - & Bali \\
\hline Waktu pelaksanaan & - & 25 November 2017 \\
\hline - Draft makalah & - & Full paper \\
\hline - Sudah dikirim & - & 31 Juli 2017 \\
\hline - Sedang direview & - & VVV \\
\hline - Sudah dilaksanakan & - & - \\
\hline
\end{tabular}

\section{SEBAGAI PEMBICARA KUNCI}

\begin{tabular}{|l|l|l|}
\hline & \multicolumn{1}{|c|}{ Nasional } & \multicolumn{1}{c|}{ Internasional } \\
\hline Bukti undangan & - & - \\
\hline Judul makalah & - & - \\
\hline Penulis & - & - \\
\hline Penyelenggara & - & - \\
\hline Nama pertemuan ilmiah & - & - \\
\hline Tempat pelaksanaan & - & - \\
\hline Waktu pelaksanaan & - & - \\
\hline - Draft makalah & - & - \\
\hline - Sudah dikirim & - & - \\
\hline - Sedang direview & - & - \\
\hline - Sudah dilaksanakan & - & - \\
\hline
\end{tabular}




\section{UNDANGAN SEBAGAI VISITING SCIENTIST}

\begin{tabular}{|l|l|l|}
\hline & \multicolumn{1}{|c|}{ Nasional } & \multicolumn{1}{c|}{ Internasional } \\
\hline Bukti undangan & - & - \\
\hline Peruguruan Tinggi pengundang & - & - \\
\hline Lama kegiatan & - & - \\
\hline $\begin{array}{l}\text { Kegiatan penting yang } \\
\text { dilakukan }\end{array}$ & - & - \\
\hline
\end{tabular}

\section{CAPAIAN LUARAN LAINNYA}

\begin{tabular}{|l|l|}
\hline HKI & - \\
\hline TEKNOLOGI TEPAT GUNA & - \\
\hline JEJARING KERJASAMA & - \\
\hline PENGHARGAAN & - \\
\hline LAINNYA & - \\
\hline
\end{tabular}

Alhamdulillah, rencana capaian yang ditargetkan untuk tahun pertama dapat tercapai dengan baik.

Yogyakarta, 10 November 2017

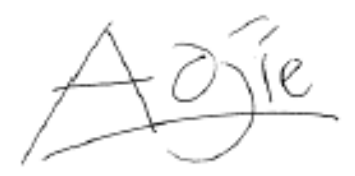

Dr. Tjahyo Nugroho Adji, MSc.Tech Ketua Peneliti 